






\section{THE VITALITY OF PLATONISM}

AND OTHER ESSAYS 


\section{CAMBRIDGE UNIVERSITY PRESS}

ZlonJon: FETTER LANE, E.C.

C. F. CLAY, MANAGer

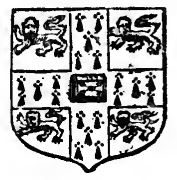

EDinfurgb: 100, PRINCES STREET

3erlin: A. ASHER AND CO.

leipzig: F. A. BROCKHAUS

felw gork: G. P. PUTNAM'S SONS

bombay and Calcutta: MACMILLAN AND CO., LTd. 


\title{
THE VITALITY OF PLATONISM
}

\section{AND OTHER ESSAYS}

\author{
BY \\ JAMES ADAM \\ LATE FELLOW AND SENIOR TUTOR OF EMMANUEL COLLEGE, \\ CAMBRIDGE
}

EDITED BY HIS WIFE

ADELA MARION ADAM

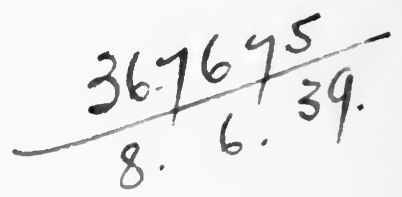

Cambridge:

at the University Press

I 9 I I 


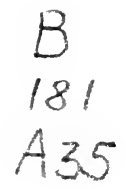

Uambrioge

PRINTED BY JOHN CLAY, M.A.

AT THE UNIVERSITY PRESS 


$$
\begin{aligned}
& \text { Toic } \\
& \text { 申iAtátolc émoi } \\
& \text { CYNECTIOIC TE Kai CYNTPATÉzOIC, }
\end{aligned}
$$

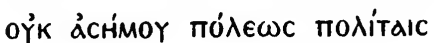

$$
\begin{aligned}
& \text { 'EMMANOYHA, }
\end{aligned}
$$

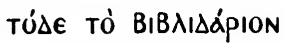

$$
\begin{aligned}
& \text { EỶMENĖC TAPÁ EỶMENOŶC } \\
& \text { кеXаріс } \theta \omega \text {. }
\end{aligned}
$$

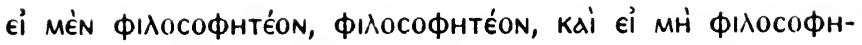

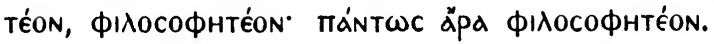

(ARISTOTLE.) 


\section{CONTENTS}

PAGE

I. The Vitality of Platonism . . . . . I

II. The Divine Origin of the Soul . . . $\quad 35$

III. The Doctrine of the Logos in Heraclitus . . 77

IV. The Hymn of Cleanthes . . . . . 104

V. Ancient Greek Views of Suffering and Evil . I 90

VI. The Moral and Intellectual Value of Classical Education . . . . . . . . 213 


\section{PREFACE}

THESE essays were read by my husband as 1 papers or lectures on various occasions. The Divine Origin of the Soul was published in Cambridge Praelections, 1906, and The Moral and Intellectual Value of Classical Education in the Emmanuel College Magazine, Vol. vii. I have to thank the Syndics of the Cambridge University Press and the editor of the magazine respectively for their kind permission to reprint them. The Vitality of Platonism was read to the Classical Society at Aberdeen University in 1902, and to a similar society in Edinburgh in the following year. The Doctrine of the Logos in Heraclitus is a paper read before the Oxford University Philological Society in 1906. The essay entitled The Hymn of Cleanthes contains the substance of three lectures delivered in 1906 at Westminster College, Cambridge, before a Summer School of Theology. The remaining essay on Ancient Greek Views of Suffering and Evil was the author's last public lecture, which 
was given to the Vacation Biblical Students at Newnham College, Cambridge, in 1907, one month before his death.

In preparing this volume for the press it has not seemed possible altogether to eliminate overlapping between the essays among themselves or with James Adam's book on The Religious Teachers of Greece. When ideas and illustrations recur, it is usually in a different setting, and they fulfil a special purpose in the separate essays.

Dr Giles has been kind enough to read the proofs, and $\mathrm{Mr}$ Leonard Whibley to give advice concerning the MS and its arrangement.

I have prefixed to the book the dedication and motto originally set before the last essay. It is fitting that the expression of my husband's love for the college where he worked should introduce these echoes of his teaching.

A. M. A.

May, гіп I. 


\section{I \\ THE VITALITY OF PLATONISM}

A distinguished philosopher, speaking of the educational value of Plato and Aristotle, remarked on one occasion that he had grave doubts whether it was expedient to make men study "dead philosophies, imperfectly understood." It might fairly be said in reply that no philosophic system which is worth studying at all has ever been perfectly understood, except, perhaps, by its inventor; and some have actually doubted whether Hegel was always intelligible even to himself. But it is a much more disputable assertion to say that Platonism is dead, and if one were to join issue with so bold an antagonist on his own ground and fight him with his own weapons, we should be tempted to maintain on the other hand that Platonism, so far from having joined the majority, is not even sickly or moribund, but rather the only philosophy which is really alive. Like Teiresias in the realm of shades, Plato, we

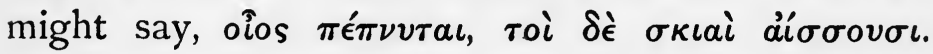
But I am far from making any such reflection upon other philosophic systems, and will content myself with trying to show that the announcement of the death of Platonism is a little premature.

A. E. 
It is at all events a curious and significant sign of Plato's continued vitality that we often find modern philosophers displaying an almost pathetic anxiety to father their doctrines upon him. Take for example Lotze, who after explaining his own metaphysical principles, proceeds to identify them with the Platonic Ideas, which he interprets, as philosophers are apt to do, in the light of his own theory. The truth which Plato intended to teach, says Lotze, is no other than that which we have just been expounding, that is to say, the validity of truths as such, apart from the question whether they can be established in relation to any object in the external world, as its mode of being or not $^{1}$. I have elsewhere ${ }^{2}$ tried to show that Lotze's application of his own metaphysical doctrines to those of Plato involves an entirely erroneous view of Plato's theory of Ideas: but it is a striking proof of the vitality of Plato's authority and name that successive generations of idealists are so apt to shelter themselves beneath his wing. And if the influence of Plato's teaching is still alive in modern philosophy, and affects, as in point of fact it does affect, nearly every revival of idealism, it is hardly less dominant in theology and religion. Some of the early apologists for Christianity, such as Justin Martyr, Clement of Alexandria, and Origen, show that they recognised and acknowledged the connection between Platonism and the Christian faith when

1 Logic, E. T. ${ }^{2}$ p. 2 Iо.

${ }^{2}$ Adam, Republic of Plato, vol. ii. $169 \mathrm{f}$. 
they speak of Greek philosophy as a preparation for Christianity, and assert, as Clement does, that Plato

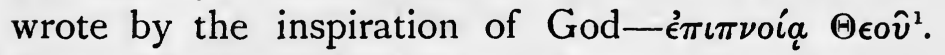
Few writers have had more influence in shaping the course of theological thought in England than the Cambridge Platonists of the 17 th century, Cudworth, John Smith, Nathanael Culverwel, and others ; and the fundamental principles of this school or band of thinkers were derived from a study of Platonism, which was uncritical indeed, and often mistaken, but always apprehended with the firmest grasp the central doctrine of Plato's religious teaching, the essential divinity of the human soul. In a later generation Ackerman and Baur, in their treatises on the Christian elements in Plato, and on Socrates and Christianity, discussed the relationship between Platonism and Christianity with a keener insight and a surer criticism, and pointed out many striking coincidences between the two systems. And to take a still more recent example, Bishop Westcott, nearly all of whose theological writings are coloured by Platonism, has declared that the myths of Plato answered in the first place to Revelation, as an endeavour to enrich the store of human knowledge, and in the second place "to the Gospel, as an endeavour to present, under the form of facts, the manifestation of Divine Wisdom."..."Plato," he says, "points us to St John"."

The stimulus exerted by Platonism on poets and

${ }^{1}$ Coh. ad Gent. I80 A, Migne.

"Contemporary Revieze, iI. p. 480 f. 
artists has been hardly less remarkable. In spite of the severe and almost puritanical regulations by which Plato in the Republic tries to clip the wings of Poetry and Art, the artistic temperament has in all ages been powerfully attracted by his writings, and it is highly significant of the intellectual affinity between Plato and Ruskin that in drawing up a list of books worth reading Ruskin took his pen and wrote "Plato, every word." The Platonic conception of an eternal self-existent principle of Beauty, standing serene and changeless above all the fluctuations of fashion and taste, has proved an inexhaustible fountain of inspiration to some of the greatest painters and sculptors in the most flourishing and creative period of Italian art. Perhaps the most noteworthy example of the influence of Plato's idealism on the artistic imagination is that of Michael Angelo, who was a member of the Platonic Academy at Florence, and gives expression to the idea which vitalises all his greatest work in language which might have come from Plato himself. One of his sonnets, translated by Wordsworth, contains these truly Platonic lines:-

Heaven-born, the Soul a heaven-ward course must hold ${ }^{1}$;

Beyond the visible world she soars to seek

(For what delights the sense is false and weak)

Ideal Form ${ }^{2}$, the universal mould.

The wise man, I affirm, can find no rest

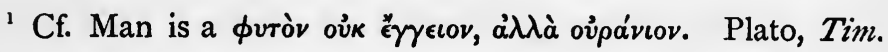
$90 \mathrm{~A}$.

Cf. Platonic Ideas. 
In that which perishes: nor will he lend

His heart to aught which doth on time depend ${ }^{1}$.

The fact is that Platonism, if we understand the word in a broad and literal, and not in a narrow or pedantic sense, is not yet dead, and cannot die, because its roots are struck deep in universal human nature. It is true that in the popular language of his time Plato speaks of the barbarian as the natural enemy of Greece; it is true that he calls his own ideal republic emphatically a Greek city; but the animating spirit of his teaching, as we shall see, is the enthusiasm of humanity, and leaves no room for the artificial distinctions of barbarian and Greek, bond and free. To the most characteristic principles of Greek life and thought he is constantly opposed. The old and all but universal rule of pagan morality, "do good to your friends, and evil to your foes" is attacked by him in the Republic and elsewhere ${ }^{2}$ with arguments based on a loftier view of man's nature and work than anything which we meet with in Greek literature before his time, and the practical conclusions which he draws "that the good man never does evil to any," "that it is better to suffer than to do wrong," have justly been held to foreshadow the Sermon on the Mount. "Ye have heard that it hath been said, Thou shalt love thy neighbour, and hate thine enemy. But I say unto you, Love your enemies, bless them that curse you, do good

${ }^{1}$ Cf. $\gamma^{\prime} \boldsymbol{\epsilon} \in \sigma \iota s$ as opposed to ov̉ría, and time as opposed to eternity. See Plato, Rep. 509 в et passim.

${ }^{2}$ Rep. 335 A ff., Crito 49 c, Gorg. 472 D ff. 
to them that hate you, and pray for them which despitefully use you and persecute you." Plato does not go so far as this, but he is following the same road. On questions like the training and work of women, the true functions of statesmanship, the theory and practice of education, and many others which might be named, Plato is equally hostile to prevalent Greek ideas. But in nothing does he display so marked an antagonism to contemporary thought and feeling as in his attitude to Greek theology and religion. Starting from the fundamental principles that the divine nature is good, immutable, and cannot lie, he attempts to show, with more refinement perhaps, but hardly less vigour, than Tertullian, that the Olympian theology violates these canons at every point. His diatribes against the religion and theology of Homer and Hesiod, who were regarded by the Greeks as the founders of their theogony, were perhaps the severest blow which paganism suffered before the Christian era, and may fairly be considered as preparing and

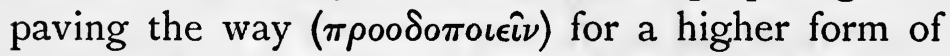
religious belief. In the words of Clement of Alexandria, $\pi \rho \circ \pi \alpha \rho a \sigma \kappa \epsilon v a ́ \zeta \epsilon \iota-\dot{\eta} \phi \iota \lambda o \sigma o \phi i ́ a, \pi \rho \circ o \delta \circ \pi \circ \iota v \hat{\sigma a}$

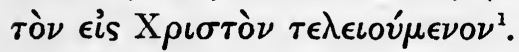

These considerations make it clear that the genius of Plato is by no means exclusively Greek, and that in many points his teaching is directly opposed to some of the most cherished beliefs of his own age. Even his political sympathies are ${ }^{1}$ Str. I. 7 I 7 D, Migne. 


\section{Appeal to universal aspirations}

Panhellenic rather than Athenian, and his philosophy, though reared on the soil of Attica, appeals, as I have already hinted, to certain universal elements in human nature, and not to Hellenic human nature only. For this reason he is careful to place his ideal city under the protection, not of Athena, the patron goddess of Athens, or any other divinity peculiarly associated with one particular branch of the Hellenic race: he commits it to Apollo, the god of Delphi, the symbol of Greek unity, aye, and something more, the God of the whole human race, so far as antiquity recognised such a God of all, the commune humani generis oraculum, the ancestral interpreter, who seated on the holy stone in the centre of the earth expounds the Father's will to all mankind ( $\pi \hat{a} \sigma \iota \nu$ à $\theta \rho \omega \dot{\theta} \pi \circ \iota, \operatorname{Rep} .427 \mathrm{c})$. And what are these universal human instincts and aspirations to which Platonism makes appeal? It is said that when Anaxagoras was asked for what purpose he was born, he replied "In order that I may look upon the heavens and the sun," and some of Plato's contemporaries were fond of deriving the word $\ddot{a} \nu \theta \rho \omega \pi \circ$ from $\dot{o} \tau \grave{\alpha} \stackrel{a}{\nu} \nu \omega \dot{a} \theta \rho \hat{\omega} \nu$, the creature whose eyes are directed on the heavenly places, in distinction from the lower animals, whose eyes are bent downwards on the earth ${ }^{1}$. In a deeper sense it is perhaps true that Nature has implanted in all mankind an unquenchable longing for the things that are above: $\tau \grave{\alpha} \grave{a} \nu \omega \phi \rho o \nu \epsilon i \tau \epsilon, \mu \grave{\eta} \tau \grave{a} \dot{\epsilon} \pi \grave{\imath} \gamma \hat{\eta} s$. So Plato at least believes, in common with an innumerable

${ }^{1}$ Cf. Lactantius, Div. Instit. II. c. I. 
company of the greatest and noblest in every age, and it is to this inborn passion for perfection that he appeals - this innate though often unconscious yearning after the ideally true and beautiful and good, which finds its highest embodiment in lives devoted to the service of Knowledge, Art, Humanity, and God. The philosophy of Plato furnishes the most poetical and perhaps the truest answer to

\section{"those obstinate questionings \\ Of sense and outward things"}

which are the heritage of human nature: it is the most inspiring philosophical expression of

"those first affections,

Those shadowy recollections,

Which, be they what they may,

Are yet the fountain light of all our day,

Are yet a master light of all our seeing;

Uphold us, cherish, and have power to make

Our noisy years seem moments in the being

Of the eternal Silence: truths that make,

To perish never;

Which neither listlessness, nor mad endeavour,

Nor Man nor Boy,

Nor all that is at enmity with joy,

Can utterly abolish or destroy!"

It is because Plato has attempted, and attempted with more success than others, to satisfy these permanent aspirations of humanity that his philosophy still lives, and is likely to live

"While water flows and tall trees bloom in spring"

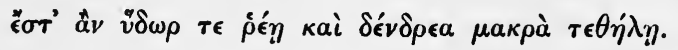


The ancients were in the habit of saying that if the Muses spoke in Greek, they must have spoken with the tongue of Plato. But it is not only in his style and language that Plato is poetical: his philosophy itself is steeped in poetry, and we shall altogether fail to understand his significance in the history of human thought unless we realise this indisputable fact. On this account I shall have frequent recourse to modern poetry in seeking to explain and illustrate the vitality of Platonism, and in particular to the poetry of Wordsworth and Tennyson, whose writings are often tinged by philosophic thought. The method which I propose to follow is to give an outline of Plato's teaching, first on Nature and secondly on human nature, adding parallels and illustrations, chiefly from Tennyson and Wordsworth, as opportunity occurs. It is impossible within the time at my disposal to touch on all the leading doctrines of a wiiter who ranges with almost equal authority over the entire domain of human life and thought, but if I succeed in showing you that Plato's philosophy of Nature and especially of human nature is not yet dead, my discourse may prove at least a finger post to point the way-an

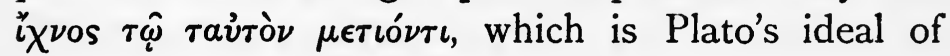
what a lecture ought to be.

Perhaps the best way to approach the subject of Plato's conception of Nature will be to start from the Timaeus. The central idea of that great dialogue is the analogy between the Macrocosm and the microcosm, the Universe and man. Let us 
consider the Universe first. The world in which we live, says Plato $^{1}$, is the product of two causes, Necessity and Perfect Reason. Necessity performs the function of the passive or material cause, and is in fact nothing but the personification of the original, inchoate, indeterminate material substratum, like the $\pi \rho \omega^{\prime} \tau \eta{ }^{i} \lambda \eta$ of Aristotle. Ideal Reason, in the person of the $\delta \eta \mu \iota о v \rho \gamma o$ s or Creator, plays the part of the efficient or creative cause, and evolves order out of the chaos of blind necessity, stamping formless matter with mathematical forms, "which are themselves copies of the Eternal Essences or Ideas, moulded from them in a mysterious and wonderful way ${ }^{2}$ " It is thus that the body of the Universe is framed. But as in man there is soul as well as body, so also in the Universe. The Soul of the World is first compounded by God himself out of the changeless and the changeful, and then "in the midst of the Universe," as Plato tells us, "he set Soul, and drew it through the whole framework, yea and wrapped the whole body of the Universe with a covering of Soul, and made it a sphere for revolving in a circle, one only Universe in lonely splendour, but able by reason of its excellence to be its own companion, and needing no other, being sufficient to itself for acquaintance and friend. In this way he begat that happy God, the Universe.".

Now I will ask you to believe that this halfpoetical, half-religious idea of a World-Soul, which

1 Tim. 47 E ff.

${ }^{2}$ Ibid. $5 \circ \mathrm{c}$.

3 Ibid. 34 B. 
according to Plato is as it were the incarnation of the Divine Reason, less perfect indeed than God himself but still wholly rational and far from anger or desire -I will ask you to believe that this World-Soul or World-Reason is in reality Plato's conception of Nature. I think a careful study of the Timaeus will convince you that the identification is sound. And if the Soul of the World which God creates in the Timaeus is in reality Nature, see what follows. It follows that Nature, as Dante somewhere says, is the child of God, that she is a spiritual and not a material creature, good and not evil ; for God, according to Plato, is the author only of good, and evil cometh not from him. In Plato's way of thinking God and Nature are not two mutually opposing forces, but an omnipotent Father and a loyal son, working harmoniously together toward

"that far-off divine event

To which the whole Creation moves,"

when Necessity shall bow the knee, and Good prevail. The fact is that it is Plato, and not Aristotle, who founded the theological view of the Universe, and Aristotle is only Platonising when he says that God and Nature do nothing in vain. We may add that from another point of view Nature is in Plato at once the revelation of God to man and God's vice-gerent, ever indwelling in the world of space and time.

So much at present for Plato's idea of Nature. Other important points will come to light of them- 
selves, when I describe his view of human nature, which I now proceed to do.

Plato was profoundly attracted by Nature, but he felt an even deeper interest in man. In this respect he is the true successor of his master Socrates. The essential nature and history of humanity, with all its hopes and enthusiasms, with all its infinite possibilities for good and evil, is the dominant theme of nearly all his greatest dialogues. It would seem that his conception of the Universe itself is in reality suggested and conditioned by his view of man. The Universe is a "magnus homo," and has a Soul, purer indeed and grander than the soul of man, but essentially the same in kind; and just as the truest nature of man is to be sought in his soul and not in his body, so also, as we have seen, it is the Soul, and not the Body of the Universe which constitutes the Nature of the Whole.

What then, according to Plato, is the nature of man? As he appears in this life, man "is a compound of the mortal and the immortal, standing midway between corruptibility and incorruptibility:

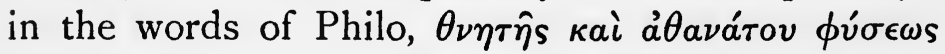
$\mu \epsilon \theta$ ó $\iota \nu^{1}$." The mortal part is the body, and its affections and lusts, which Plato in the Timaeus calls

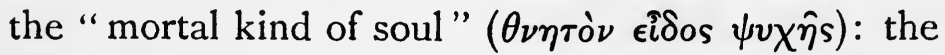
immortal part is Reason, the eye of soul, the lamp of human life, the representative of God in man, the candle of the Lord. The mythical creation of the rational part of our souls by God is thus ${ }^{1}$ De Mund. Opif. 46. See Adam, Republic of Plato, 588 в. 
described by Plato. After the Creator had compounded the Universal Soul "again into the same cup, in which he blended and mingled the Soul of the Universe, he poured that which was left of the former elements, mingling them in somewhat the same way, yet no longer so pure as before, but one or two degrees less pure.". In other words the rational or immortal part of soul, for it is that alone which comes immediately from God himself, is made of the same elements as the Soul of the Universe. Now we have already seen that Plato thinks of the World-Soul as Nature, and I would have you observe what follows as to the relationship existing between Nature and man. Every vestige of hostility and antagonism disappears; and Nature, instead of being "red in tooth and claw with ravine," is man's elder brother co-operating with him and the universal Father in one great Trinity of beneficence and love against the stubborn and malignant forces of Necessity and Chaos. It has been said that it is a good thing to have a devil in the world, so long as you keep your foot on his neck. War is the

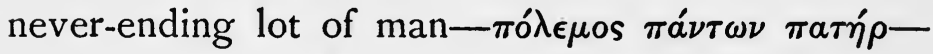
and in the struggle against evil we have the gods for our allies. The general conception of a natural affinity or kinship between God and man, and man and Nature was not invented by Plato. It was a familiar Greek idea that men are but "mortal gods," and gods "immortal men"," and Pindar was only

1 Tim. 4 I D.

2 These words are put into Heraclitus' mouth by Lucian, Vit. Auct. I 4. 
expressing a common belief when he sang "one is the race of men and gods: and from one mother we both inherit the breath of life ${ }^{1}$." There is also reason to believe that the same inspiring conception had already even before the time of Plato assumed a deeper and more religious significance in Orphic and Pythagorean teaching. The unity between man and nature, again, was an underlying hypothesis of Greek life; and the life in harmony with Nature, that is, with the Nature of the Whole, is an ideal which expresses much of the best Greek thought even before the days of Stoicism. But Plato is the first of the Greeks to make the kinship of the divine and human natures the basis of a philosophy of man, and he expounds the doctrine with more emphasis than any pre-Christian thinkers except the Stoics, and with a far greater wealth of philosophic meaning than any other writer in any age.

At this stage I will invite you to pause for a moment and consider the affinity between this view of Nature and that with which we meet in the poems of Wordsworth. The subject of Wordsworth's Platonism has already been briefly touched upon by the author of John Inglesant, in a paper read to the Wordsworth society in $\mathrm{I} 88 \mathrm{I}$ : and I observe that a critic in the Times of to-day (March 20, I903) pronounces Wordsworth "the profoundest, the most daring Platonist in English literature." $\mathrm{Mr}$ Shorthouse lays stress upon a remarkable passage from the Excursion and finds in it "the key not 
only to Wordsworth's Platonism, but to that peculiar conception of his that an entrance into the world of abstract thought may be won by the help of material objects ${ }^{1 . "}$ The lines of Wordsworth are :-

"While yet a child and long before his time

Had he perceived the presence and the power

Of greatness: and deep feelings had impressed

Great objects on his mind, with portraiture

And colour so distinct, that on his mind

They lay like substances, and almost seem'd

To haunt the bodily sense?."

"“The presence and the power of greatness,", says Shorthouse-"this is that "principle of excellence' in which Plato believed." The poet seems to affirm that by the help of the vast objects of nature, perceived in silence and in solitude, we are enabled to understand and to conceive the great realities of abstract thought, and to

"breathe in worlds

To which the Heaven of Heavens is but a veil."

These remarks are suggestive and true; but in what I have to say of Wordsworth's Platonism I will pursue a somewhat different, and for some of you perhaps an easier line of thought, confining myself to Wordsworth's view of Nature and her relation to man. It seems to me that the philosophical idea which underlies nearly all the finest poetry of Wordsworth is no other than that which we have already found in Plato, although the English poet develops it in a somewhat different

1 p. 12.

s Book I. 
way from the Greek philosopher. To Wordsworth as to Plato, Nature is a Soul or Spirit, and divine:

"O Soul of Nature! that by laws divine Sustained and governed, still dost overflow With an impassioned life ${ }^{1}$ !"

And just as in Plato Nature imitates God, and is created by Perfect Wisdom, so in Wordsworth Nature is

\section{"a Power}

That is the visible quality and shape

And image of Right Reason: that matures

Her processes by stedfast laws; gives birth

To no impatient or fallacious hopes,

No vain conceits: provokes to no quick turns

Of self-appiauding intellect; but trains

To meekness, and exalts by humble faith"."

In more than one passage Wordsworth appears to conceive of Nature as an indwelling soul, like Plato's Soul of the Universe:

"To every form of Being is assigned

An active Principle:

it subsists

In all things, in all natures; in the stars

Of azure heaven, the unenduring clouds,

In flower and tree, in every pebbly stone

That paves the brooks, the stationary rocks,

The moving waters, and the invisible air.

Spirit that knows no insulated spot,

No chasm, no solitude; from link to link

It circulates, the Soul of all the Worlds ${ }^{3} . "$

1 Prelude, Book xiI.

${ }^{2}$ Ibid. Book XIII.

3 Excursion, Book Ix. ad init. 
It is in this spirit that Wordsworth finds the true and essential unity of Nature,

"Even as one essence of pervading light

Shines in the brightest of ten thousand stars

And the mute moon that feeds the lonely lamp

Couched in the dewy grass ${ }^{1} . "$

With this may be compared the passage from the Lines composed a few miles above Tintern Abbey beginning

"I have felt

A presence that disturbs me with the joy

Of elevated thoughts.".

And it is the same idea to which the poet gives magnificent expression in his description of the scenery of Switzerland :-

"The immeasurable height

Of woods decaying, never to be decayed,

The stationary blasts of waterfalls,

And in the narrow rent at every turn

Winds thwarting winds, bewildered and forlorn,

The torrents shooting from the clear blue sky,

The rocks that muttered close upon our ears,

Black drizzling crags that spake by the wayside

As if a voice were in them, the sick sight

And giddy prospect of the raving streams,

The unfettered clouds and region of the Heavens,

Tumult and peace, the darkness and the light-

Were all the workings of one mind, the features

Of the same face, blossoms upon one tree;

Characters of the great Apocalypse,

The types and symbols of Eternity,

Of first, and last, and midst, and without end ${ }^{3}$."

'Prelude, Book xiv.

${ }^{2}$ Quoted infra, The Divine Origin of the Soul, p. 48.

${ }^{3}$ Prelude, Book vi.

A. E. 
And in her relations with man, how kind, and beneficent is Nature! What lessons of moderation and calm she teaches us! What strength and consolation we derive from communion with the "kindred spectacles and sounds" of nature, "the noise of wood and water," the starry heavens, the sea, the "everlasting hills"! Of these and similar ideas the poetry of Wordsworth is full, and quotations would be superfluous. I will only add that Wordsworth, like Plato, is never forgetful of man when he writes of Nature. As Shorthouse says, if "Nature elevates man," "man consecrates Nature"- "man and Nature act and re-act"." And thus it is that no one who is not a friend of man can hope to understand the voice of Nature.

"But this we from the mountains learn

And this the valleys show,

That never will they deign to hold

Communion where the heart is cold

To human weal and woe.".

It is

"the still sad music of humanity"

that Nature sings,

"Not harsh nor grating, though of ample power

To chasten and subdue ${ }^{3}$."

These quotations, which might be greatly multiplied, may seem perhaps to show you that there is a strong vein of Platonism in Wordsworth.

${ }^{1}$ p. 6 of paper quoted above.

- Lines composed at Cora Linn.

${ }^{3}$ Lines composed a few miles above Tintern Abbey. 
$\mathrm{Mr}$ Shorthouse is unwilling to assert that Wordsworth "consciously Platonized; on the contrary, it is not likely that he ever read the Dialogues." I do not feel sure of this, but all that I wish at present to maintain is that Wordsworth's interpretation of Nature has its philosophical basis whether consciously or unconsciously in Platonism. Let us now return to Plato himself.

The famous words in which Plato proclaims that man is "a celestial and not a terrestrial plant" -

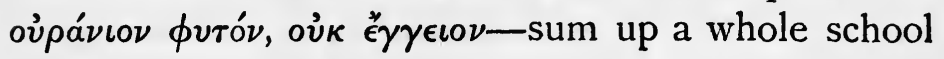
of theological and religious thought. You remember the passage in which St Paul addresses the Stoic and Epicurean philosophers on the Areopagus at Athens: "God hath made of one blood all nations of men for to dwell on all the face of the earth, and hath determined the times before appointed, and the bounds of their habitation: that they should seek the Lord, if haply they might feel after him, and find him, though he be not far from any one of us : for in him we live, and move, and have our being: as certain also of your own poets have said, For we

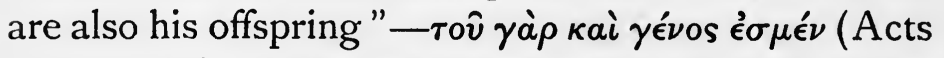
$x$ vii. 26-28). These sentences are full of Stoic moral and religious teaching, and the sentiment with which they conclude, though it may have been derived by Paul from the Phaenomena of Aratus, who uses the same quotation in the second century before Christ -or possibly from Aristobulus of Alexandria-this profound conviction of the universal brotherhood of

Tim. 90 A. 
men and their relationship to God the Father reaches back through the hymn of Cleanthes the Stoic to the great Platonic doctrine which I have named. It is the same belief in the celestial origin of man that inspires the teaching of some of the early fathers of the Church, such as Justin Martyr, Clement of Alexandria, and Origen, nor has it lost its power to move the minds and sway the hearts of men to-day. Perhaps it is not too much to say that the $\dot{\epsilon} \boldsymbol{\kappa} \sigma o \hat{v}$

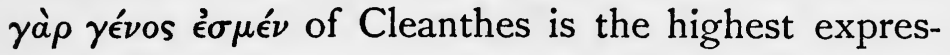
sion of the religious sentiment in the whole range of Greek literature and not unworthy to rank with the Christian equivalent: "Our Father which art in Heaven." In the presence of this spiritual affinity the distinction between Pagan and Christian seems to fade away, and we have a momentary vision of an ideal faith, a $\pi \alpha \rho a ́ \delta \epsilon \iota \gamma \mu \alpha \dot{\epsilon} \nu$ ov่ $\rho \alpha \nu \hat{\omega}$, whereof all earthly religions are but shadows pointing to the perfect day.

Plato's position on this subject is that he believes it to be just the presence of this divine element in man which renders his nature most distinctively and most specifically human". The "colour and likeness of true manhood," says Plato in the $R e$ -

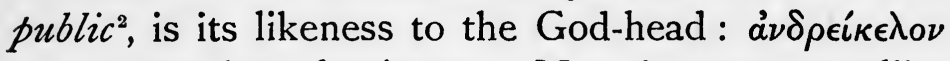

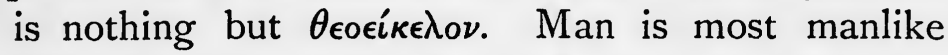
when he most resembles God, and (as Tennyson says) "then most godlike being most a man." The lower appetites which clog and thwart the soul are no part of man at all : they are of the earth, earthy,

${ }^{1}$ See Adam, notes on Rep. 501 B, 589 D. 
whereas man is a child of Heaven. It is the higher which is the human nature, and according to this higher nature man must be defined and placed. The noble lines of George Herbert, which I have elsewhere quoted to illustrate this subject, express the teaching of Plato better than anything that I can say, and may at the same time serve to show you that whether Platonism is a dead philosophy or not, it may sometimes be a living faith.

"To this life things of sense

Make their pretence:

In th' other Angels have a right by birth:

Man tries them both alone,

And makes them one

With th' one hand touching heav'n, with th' other earth,

In soul he mounts and flies,

In flesh he dies,

He wears a stuffe whose thread is coarse and round,

But trimm'd with curious lace;

And should take place

After the trimming, not the stuffe and ground ${ }^{1}$."

Of this doctrine of the essential divinity of man I have said in another place that "the sure and abiding conviction of the presence of a divine element within us, rendering our nature essentially and truly human, makes itself felt in nearly all the dialogues of Plato. It is the ultimate source of all his idealism, religious and metaphysical, no less than moral and political, and may well be considered the most precious and enduring inheritance which he has bequeathed to posterity ${ }^{2}$." To me this doctrine

${ }^{1}$ Man's Medley.

Note cn Rep. 5 о в в. 
appears to be more fundamental than anything else in Plato, except perhaps the theory of Ideas, with which it stands in close relationship; and it is assuredly the most living, aye and life-giving of all Platonic doctrines. Let us endeavour for a moment to understand how it is connected with other parts of Plato's teaching-such as his theory of knowledge, the pre-existence and immortality of the soul, and the aim and scope of education.

The only true objects of knowledge, according to Plato, are the transcendent, self-existing Ideas, which are poetically described in the myth of the Phaedrus. These Ideas, which are themselves the only true realities, on the model of which the visible Universe and all its parts are fashioned, depend in turn upon the one supreme or sovereign Idea, that is the Good, so that the whole Universe of thought and things is, if we may adopt a phrase

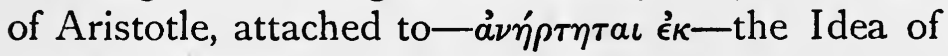
Good or God. Or to change the figure, we may say that the totality of existences is one long altar-stair, ascending step by step from the lowest to the highest,

"Through the mighty commonwealth of things,

Up from the creeping plant to sovereign man,"

and higher still through all the infinite gradations of the spiritual world, whose lamp or sun is God himself. Both conceptions are Platonic, and both are also Tennysonian:

"For so the whole round earth is every way

Bound by gold chains about the feet of God"."

1 Wordsworth, Excursion, Book Iv.

' Morte d'Arthur. 


\section{And again :}

"the great world's altar-stairs

That slope through darkness up to $\mathrm{God}^{1}$."

To these transcendent Ideas, and especially to the Idea of Good, the human soul, in virtue of its inherent divinity, is akin, and by reason of its kinship with the ideally true and beautiful, it is able to apprehend perfection.

As the Cambridge Platonists in the seventeenth century loved to say, Man's Reason is the candle of the Lord, lighted by God himself, to guide the soul on high. In the words of Nathanael Culverwel, perhaps the most truly eloquent of that illustrious band of writers and thinkers: "The Candle of the Lord it came from him, and 'twould faine return to him,...the face of the soul naturally looks up to God, coelumque tueri jussit, et erectos ad sidera tollere vultus, 'tis as true of the soul as of the body. All light loves to dwell at home with the Father of Lights. Heaven 'tis Patria luminum, God has there fixt a tabernacle for the Sun, for 'tis good to be there, 'tis a condescension in a Sunne-beam that 'twill stoop as low as earth, and that 'twill guild this inferiour part of the world; 'tis the humility of light that 'twill incarnate and incorporate it self unto sublunary bodies; yet even there 'tis not forgetful of its noble birth and original, but 'twill still look upwards to the Father of Lights.".

1 In Memoriam, 55.

${ }^{2} A$ discourse of the Light of Nature, ist Ed., p. 199. 
It is in this way that the doctrine of the divinity of the human soul is connected with the Platonic theory of knowledge. How is it related to the teaching of Plato on pre-existence and immortality? Throughout the whole of Greek literature, from Homer downwards, immortality is universally held to be an attribute of that which is divine, and it is a wide-spread principle of Greek philosophy that

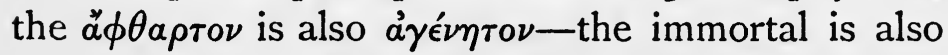
the uncreated. Each of these principles is fully accepted by Plato, and although in the Timaeus he speaks of the creation of the human soul by God, that is in all probability only an allegorical way of saying that the soul of man is an efflux or fragment -ámó $\sigma \pi a \sigma \mu a$, as the Stoics said-of the divine Soul. It certainly does not imply that Soul as such had a beginning in time. In this way the divinity of Soul implies at once its pre-existence and its immortality. To tell the story of the Soul as Plato tells it, mingling poetic fancy with moral and religious truth, and "o'erlaying all with the Muses' charm" - musaeo contingens cuncta lepore-would require the genius of another Plato. Each particular soul has an endless history behind it, and an infinite prospect before. Incarnation is only an episode in a life that stretches through both eternities, a halting-place, or shall we say a quiet haven? Nay rather a troubled and storm-tossed sea, a prisonhouse in which the soul is chained till Death, the great deliverer, sets her free, a tomb in which soul lies dead, until death's resurrection morn shall bid 
the shadows flee away. We are again reminded of St Paul: "O wretched man that I am, who shall deliver me from this body of death ?" (Rom. vii. 24). "For we that are in this tabernacle do groan, being burdened : not for that we would be unclothed, but clothed upon, that mortality might be swallowed up of life" (2 Cor. v. 4). Or in the words of St Peter, both of whose epistles furnish many analogies to the

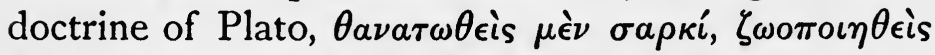
$\delta \dot{\epsilon} \pi \nu \epsilon \dot{v} \mu a \tau \iota$ - the death of the body makes the spirit alive. Before the round of incarnation began, says Plato in the Timaeus", God "set each soul as it were in a chariot and showed her the nature of the whole," in harmony with which it is her duty to live; and in the interval between each successive incarnation, the soul that has strenuously followed truth and righteousness on earth, renews her faded fires and plumes her wings afresh by gazing on the perfect forms of Beauty and Truth in the realms of the Ideas. And when she returns to earth again, if she have drunk not too deeply of that "daughter of Lethe," that awaits "the slipping through from state to state" it may often happen that a stray sunbeam from the heavenly kingdom enters the window of the prison-house and reminds her of the "imperial palace whence she came," making her to rejoice and sing like "Memnon smitten with the morning sun." This is the Platonic form of that doctrine of Reminiscence or Recollection with which we so 
often meet in English poetry. It is this which inspires the lines of Tennyson:-

"Moreover, something is or seems, That touches me with mystic gleams, Like glimpses of forgotten dreamsOf something felt, like something here; Of something done, I know not where; Such as no language may declare ${ }^{1 . "}$

The same thought is expressed by Boethius ${ }^{2}$

"Who for a good he knows not sighs? Who can an unknown end pursue? How find? How e'en when haply found Hail that strange form he never knew? Or is it that man's inmost soul Once knew each part and knew the whole?

"Now, though by fleshly vapours dimmed, Not all forgot her visions past; For while the several parts are lost, To the one whole she cleaveth fast; Whence he who yearns the truth to find Is neither sound of sight nor blind.

"For neither does he know in full, Nor is he reft of knowledge quite, But, holding still to what is left, $\mathrm{He}$ gropes in the uncertain light, And by the past that still survives To win back all he bravely strives."

And it is essentially the same idea which was in the mind of Wordsworth when he wrote the Ode on the Intimations of Immortality.

1 The Trwo Voices.

2 Consolation of Philosophy, v. 3, tr. James. 
"Hence in a season of calm weather

Though inland far we be

Our Souls have sight of that immortal sea

Which brought us hither,

Can in a moment travel thither,

And see the Children sport upon the shore,

And hear the mighty waters rolling evermore."

In the prefatory note with which he introduces this poem, Wordsworth is careful to indicate that he is not committed to the doctrine of the pre-existence of the soul: he merely regards the notion "as having sufficient foundation in humanity " to justify him in using it for poetical purposes. The doctrine almost disappears from Greek philosophy, properly so-called, between the time of Plato and the Neoplatonists ; but its influence is traceable in the apocryphal literature of the Old Testament, and especially in the book of the Wisdom of Solomon. "I was a child of goodly parts," says the author of that work, " and received a good soul; or rather, being good, I

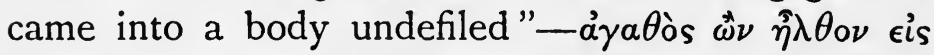
$\sigma \hat{\omega} \mu \alpha \alpha^{\alpha} \mu i \alpha \nu \tau o \nu^{1}$. It has not been accepted by the Christian Church, and now survives in Western literature chiefly as a poetic fancy. In the East, on the other hand, it is still what it was to Plato and to Origen, and in later times to Henry Moore -an integral and essential part of the belief in the eternity of Soul. The other half of Plato's doctrine has fared better; but there is no philosophical system at the present day which can be compared 
with Platonism in the extent to which it is moulded and inspired by the ever-present consciousness of immortality.

It remains for us to see in what way Plato's doctrine of the divinity of the human soul affects his conception of the scope and method of education. In our essential nature, the soul is divine ; but when incarnate in a mortal body, she is clogged and encumbered by the evils inseparable from her tenement of flesh. In these circumstances, what is the duty of the teacher? Is it, as some of Plato's contemporaries held-nor is the opinion even now extinct -is it to endeavour "to put sight as it were into blind eyes"-in other words to fill the soul with moribund facts and dogma, imperfectly understood, or rather, as Plato would say, not understood at all ? Against this view of education Plato urges unrelenting warfare, for it is the entire and absolute negation of his whole theory and practice. According to him Reason, which is the eye of the soul, present in many men and women, is never blind; although its gaze is only too often directed on the false and fleeting, the hollow and impure. The "leaden weights " of tradition, prejudice, passion and desire, drag the soul's eye downwards to that which is of the earth earthy. Who then, according to Plato, is the true and heaven-born teacher? He is one who makes it his aim, not to multiply, but to remove those leaden weights, that the soul may thus obey her native impulse and soar upwards. Or to change the figure, and avail myself of what I have ventured 
to write elsewhere, "Michael Angelo used to say that every block of marble contained a statue, and that the sculptor brings it to light by cutting away the encumbrances by which the 'human face divine' is concealed. In like manner, according to Plato, it is the business of the teacher to prune the soul of his pupil of those unnatural excrescences and incrustations which hide its true nature, until the human soul divine stands out in all its pristine grace and purity"." Or yet again, the teacher is a kind of revolutionist, seeking to turn round the soul of his pupil from darkness into light. In this process of revolution or circumversion- $\pi \epsilon \rho \iota \gamma \omega \gamma \eta^{\prime}$ is the Greek word-the moral as well as the intellectual part of our nature shares. Plato is most careful to point this out ${ }^{2}$, and he would have refused to admit that it is possible for the intellect to be transformed without a corresponding transformation of the moral nature. But the transformation is effected, according to Plato, through the Reason, which is the element of God within us, rather than through the will, and it is the development of the reason and the reasoning. faculties which his curriculum of studies in the Republic is primarily intended to produce.

What is that curriculum? Theory of Number, Plane Geometry, Stereometry, Astronomy, Harmonics and Dialectic. We need not suppose that Plato was irrevocably committed to these particular studies: he did what every great educational reformer must always do, adopted the leading scientific studies

${ }^{1}$ Note on Rep. 518 c.

${ }^{2}$ Ibid. 
of his day, and infused new life and meaning into them. But I feel sure that Plato would never have surrendered the one great principle that the avenue to the knowledge of the Ideas leads through Mathematics to Dialectic: for inasmuch as Nature is constructed by God according to mathematical laws

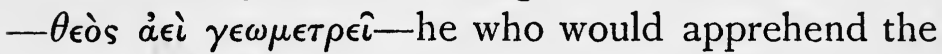
truths of Nature must travel through Mathematics to his goal ${ }^{1}$. I have elsewhere drawn attention to an interesting and, as I think, important fact in connexion with the influence of Plato's curriculum on the course of medieval academic study. You are aware that the curriculum of our Universities used to consist of a quadrivium and a trivium, the quadrivium being Arithmetic, Geometry, Music and Astronomy. These four studies you will observe correspond to Plato's five preliminary studies, Theory of Number, Plane Geometry, Stereometry, Astronomy and Harmonics: for Stereometry, as conceived by Plato, is only a branch of Geometry. Now the Platonic Academy had a continuous history till Justinian closed the philosophic schools, and we can hardly be wrong in supposing that the adoption of these studies into the medieval curriculum was due directly or indirectly to the value attached to them by the Platonic school. But there is a still more striking link cementing our Universities with the Academy of Plato and even with the fourth century B.c. In the medieval Universities those who were

${ }^{1}$ See Adam, Religious Teachers of Greece, p. 419 f.; Republic of Plato, vol. ii., p. $\mathbf{1} 68$. 
duly qualified in the quadrivium and trivium received the title of bachelors or masters of Arts, because Arithmetic, Geometry, Astronomy and Music, together with the studies of the trivium, were technically called $A r t s$. Now the interesting point to notice is that this use of the word Arts in what I may call the academic sense, actually occurs in Plato, who speaks of Number or Arithmetic, Geometry, Astronomy and Music as the so-called Arts. When the mystic cap is placed upon your heads, making you magistros or magistras artium as the case may be, I ask you to remember that you are indebted to Plato, or the age in which he lived, for part at least of this high sounding and doubtless welldeserved title.

So far, I have spoken of Plato's educational theory as if it affected our present life on earth and nothing more. But inasmuch as the faculty of reason, which the teacher tries to cherish and foster, is immortal and divine, the horizon of the teacher is not limited by this transitory life. The soul, says Plato, takes nothing with it into the unseen world except its education". Plato therefore "believes that the teacher can influence the pupil for hereafter as well as for life here, and that the soul which is once smitten with the love of truth may still advance from knowledge to more knowledge throughout unnumbered lives and phases of existence" still to come $^{2}$. If the seed appears for the moment to fall

' Phaed. ro7 D.

${ }^{2}$ Adam, Rep. of Plato, vol. ii., p. 168. 
on barren soil, the teacher may still be comforted: perchance it may yet "bloom to profit, otherwhere." "We will not," says the Platonic Socrates, "relinquish our endeavour, until we either persuade Thrasymachus and the others, or make some progress in view of the life which is to come, when in another existence we may chance on topics such as these."

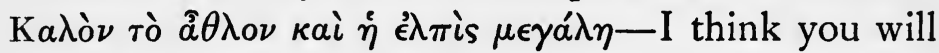
agree with me that such a theory of education upholds to us a larger prospect than the usual application of the term either in ancient or in modern times. According to the familiar saying, some of us are born Platonists, and the rest Aristotelians; and the Aristotelian will probably think that here, as elsewhere, Plato soars too high. In reply to this objection, Plato would probably say, and say with truth, that even if the goal appears to some impossible to reach, the stimulus of a great though unattainable ideal may enable them to reach the limits of that to which they can attain. Think of the heavenly pastures through which the soul is led in looking for that untravelled land. And even if we refuse to follow Plato into these loftier regions of thought and speculation, his remarks on educational theory and method furnish many lessons for the guidance of teacher and pupil even within a narrower sphere. Among these I will only mention two or three. How does Plato conceive of the relationship between the teacher and the taught? They are intellectual partners or comrades in the search for knowledge. The teacher 
is himself a learner, and the pupil a teacher; for it is from the contact of the two minds that truth or knowledge springs to light. Another lesson is that education is at once an intellectual and a moral revelation, the $\pi \epsilon \rho \iota \gamma \omega \gamma \eta^{\prime}$ of the whole nature of

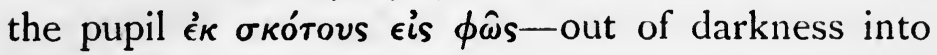
light. The ultimate goal of intellectual education, according to Plato, is the knowledge of God, and moral training culminates in assimilation to $\mathrm{His}$

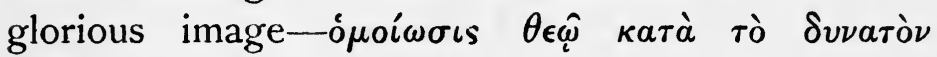
$\dot{a} \nu \theta \rho \omega \pi \omega^{1}$. This is Plato's version of man's chief end. Hardly less valuable and significant is Plato's view of education as the free and unconstrained development of the individual soul, and his conception of the means whereby this end can be attained - stimulus, the shock of surprise and contradiction, the pleasure of discovery, generalisations prematurely formed and gladly discarded in favour of new and later generalisations, destined themselves to suffer the same fate as the intellectual horizon widens and expands. These and many other kindred principles of educational theory are frequently heralded as new discoveries of the present day, as for example by Professor Armstrong, who is never weary of extolling what he calls the "heuristic" method. In point of fact, they are all of them found in Plato, and their employment in the art and practice of education is abundantly illustrated throughout his dialogues. But we shall miss the most distinctive and essential element in Plato's theory of education if we seek to

\section{Theaet. 176 в.}

A. E. 
narrow its range or isolate it from the rest of his philosophy. Plato never loses sight of the whole when treating of the part, and education in his view is but a part of life; as life itself is of eternity. The genius of Plato is always reaching forth after $\tau$ ov

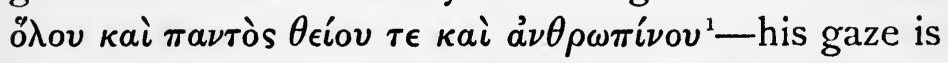

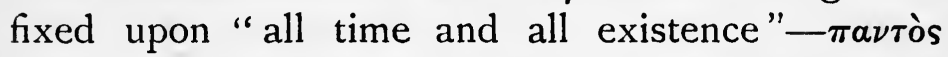

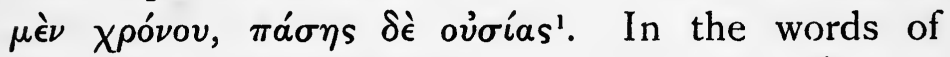
Goethe, " every utterance of Plato points to the eternal--to an eternal Unity or Whole"-ein ewig Ganzes- "an eternal principle of Goodness, Truth and Beauty which he strives to quicken and promote in every bosom "."

In Plato's description of that momentous scene in the prison-house of Athens-a scene to which there is no parallel, save only one, in human historyoccur the touching and memorable words : $a^{\prime} \lambda \lambda^{\prime}$ oi $\mu a \iota$

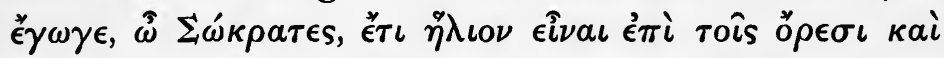
ov้ $\pi \omega \delta \epsilon \delta v \kappa \epsilon ́ \nu a l^{3}$. "Nay, Socrates, I think the sun is still upon the mountains, and has not yet set." In the considerations which I have put before you, I have hardly touched the fringe of a great and noble subject, but I hope that some of you may have at least begun to realise that Plato's sun still shines upon the everlasting hills.

\footnotetext{
1 Rep. 486 A.

2 Farbenlehre, iii. p. I41, Weimar, 1893.

3 Phaed. I 6 E.
} 


\section{THE DOCTRINE OF THE CELESTIAL ORIGIN OF THE SOUL FROM PINDAR TO PLATO}

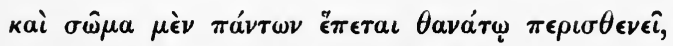

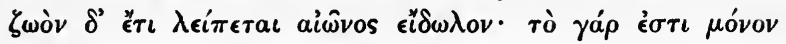

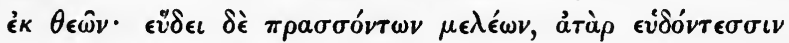
èv $\pi 0 \lambda \lambda$ oîs ỏveípots

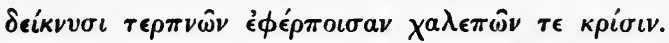

Pindar, fragment i 3 I Bergk.

The body of all men is subject to all-pozverful death, but alive there yet remains an image of the living man; for that alone is

from the gods. It sleeps when the limbs are active, but to them that sleep in many a dream it revealeth an award of joy or sorrow drawing near.

I propose in the present lecture to invite your attention to part of a remarkable fragment of Pindar's dirges, preserved by Plutarch in his Consolatio ad Apollonium. It has long been recognised that the Pindaric dirges introduce us to a circle of ideas to which Greek poetry is hitherto a stranger, although parallels are to be found in Orphic eschatology and to a certain extent also in the fragments

1 c. 35 . 
of Heraclitus. From whatever source Pindar may have derived his conception of the future world, and he certainly did not evolve it out of his inner consciousness and nothing else, the power of poetry to refine and purify religious sentiment has never been better illustrated than by the poet who throughout his whole career believed himself the chosen servant of Apollo, the god of religious and prophetical as well as of poetical inspiration. My object, however, is not to discuss the origin of these beliefs : it is rather to trace from Pindar to Plato the gradual development and progressive intellectualisation of one of the beliefs contained in the particular fragment which I have put into your hands, and incidentally, perhaps, to remark upon its significance in connexion with later developments in Poetry, Philosophy, and Religion.

A word or two is necessary with reference to the translation. ai $\omega \nu$, which I have taken as "the living man," means simply "life." Pindar is using the abstract for the concrete. In my opinion W. Christ is grievously wrong when he explains the word by aevi sempiterni, "eternity": ai $\omega \nu$ is never so used by Pindar. In the last line $\kappa \rho i \sigma \iota \nu$ means "adjudication," as $\kappa$ iv $\omega$ in a passage of the Pythians means "adjudge ${ }^{1}$ :

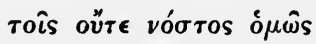

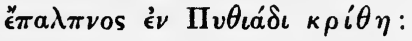

"To them, at the Pythian festival, no such glad return to home was adjudged": 
but the specific reference in our fragment, as Boeckh and other editors have pointed out, is doubtless to the adjudication of joy and sorrow at the judgment of the dead. Pindar recognises such a judgment in the second Olympian ${ }^{1}$, and implicitly also in other fragments of his $\theta \rho \hat{\eta} \nu \iota^{2}$ describing the bliss that awaits the pious, and the torments in store for the wicked. Anyone who reads the fragments of the $\theta \rho \hat{\eta} \nu \circ \iota$ side by side will agree, I think, that $\kappa \rho \iota \sigma \iota \nu$ is to be understood in this way.

Let us now turn our attention to the ideas which Pindar's words embody. We note to begin with the survival of the old Homeric notion of the soul as the shadow of the living self. The soul of Patroclus, you remember, appeared to Achilles in a vision of the night, "in all things like to the man himself, in stature and fair eyes and voice, and the raiment on his body was the same." So far, therefore, we are entirely on Homeric ground. But the rest of the passage belongs to a stratum of ideas which is unlike anything to be found in the Iliad or Odyssey. In the first place, the soul is said to be of divine descent ; secondly, this kinship with the gods is cited as a ground for believing in immortality-

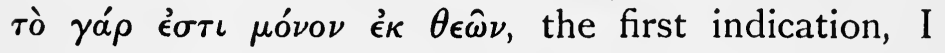
believe, in Greek literature of a definite argument for this belief, such as Plato afterwards developed in the Phaedo; and thirdly, the fundamental idea in the last two lines, the idea of which the premonitory vision of the day of judgment is one particular
2. 59 .
${ }^{2}$ I 30, I 32, I 33 Bergk.
3 II. 23.66. 
application, is that during life, so long as we are awake and conscious, the soul is asleep, but when the body is laid to rest, the soul awakes and reveals to us in visions of the night that which in our waking moments we cannot see. It is the first of these conceptions, that of the celestial origin of the soul, with whose development in Greek literature down to Plato I wish at present to deal; but we shall find that the other two ideas are closely bound up with it, and sometimes make their appearance in writers by whom the soul's divinity is affirmed.

In Pindar, as in Heraclitus, a thinker with whom the poet has other points in common besides obscurity, the celestial origin of the soul is still, what it primarily was, a predominantly religious belief; but the germs of a philosophical interpretation are already discernible when the poet deliberately founds his faith in immortality upon this doctrine, and also when by means of it he explains the possibility of divination during sleep. The particular idea involved in the latter part of the passage before us, reappears not only in the Republic. of Plato ${ }^{1}$ but also in an Aristotelian fragment, where we are told that "whenever the soul is alone and by itself in sleep, it recovers its proper nature," that is, of course, its celestial nature, "and divines and prophesies the future ${ }^{2 "}$; and the same idea lies at the root of the Stoic philosophy of divination. Nor is it, indeed, unknown in modern psychological thought. Pindar's description of the soul in this

$$
{ }^{1} \text { IX. } 572 \mathrm{~A} . \quad 2 \text { Fr. I } 2 .
$$


passage bears an obvious and striking resemblance to $\mathrm{Mr}$ Myers' theory of the subconscious or subliminal self, which, according to the hypothesis of Professor James, is the medium of communication between the soul and that higher or transcendental region which he calls God: nor did the analogy escape $\mathrm{Mr}$ Myers, for he chooses the Pindaric fragment as the heading of his chapter on Sleep ${ }^{1}$. In his Ingersoll lecture, again, Professor James makes the existence of this subliminal self the basis of an argument for immortality, precisely as Pindar says: "for this alone is from the gods." The possibility of a philosophical development of the Pindaric notion is also, I think, involved in another passage of Pindar. You will observe that here it is simply $\psi v \chi \eta^{\prime}$-soul in the old Homeric sense, or not much more-that comes from the gods. In the sixth Nemean, however, after emphatically proclaiming the original unity of men and gods-

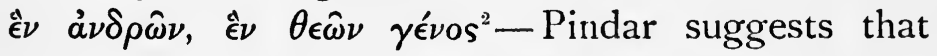
perhaps the point in which we resemble the immortals is in mind or reason $\left(\mu \epsilon^{\prime} \gamma a \nu \nu o ́ o \nu\right)^{3}$. And it is on the divinity of $\nu o \hat{s}$, rather than of $\psi v \times \gamma^{\prime}$, that Greek philosophy, as we shall presently see, chiefly insists. This, and not simply the soul or $\psi v \chi \eta^{\prime}$, is

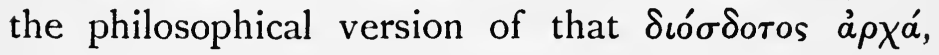
that god-given seed or germ of life which Pindar

'Human Personality, vol. I. p. I 2 I.

2 6. I. I agree with Professor Bury in his explanation of these words.

3 Ibid. 5 . 
mentions in yet another fragment ${ }^{1}$. It would be absurd, of course, to attribute to a poet any rigid psychological nomenclature; but no one denies that vov̂s in Pindar is predominantly, though not exclusively, an intellectual faculty ${ }^{2}$; and in Greek philosophy itself, even, I believe, in Stoicism, vov̂s is never the merely siccum lumen, the clear, cold light, which we are sometimes in the habit of calling reason. The dry soul, says Heraclitus, is the wisest :

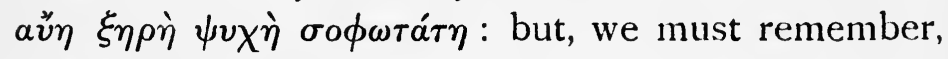
it was made of fire.

In classical Greek lyric poetry, other than Pindar, there is no certain trace of the ideas we are now considering. The younger Melanippides, who died perhaps about 413 B.C., has left a striking fragment of a prayer, addressed presumably to Dionysus ${ }^{3}$ :

$$
\kappa \lambda \hat{v} \theta i \dot{i} \mu o, \dot{\omega} \pi \dot{\tau} \tau \epsilon \rho,
$$

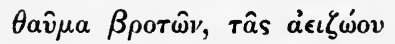

$\mu \epsilon \delta \delta^{\prime} \omega \nu \quad \psi v \chi \hat{\alpha} s$.

"Hear me, O Father, honoured of mortal men, thou that art lord of the ever-living soul."

If the whole of this poem had survived, it is possible that some further light would be thrown on the subject of this lecture. Aeschylus has one or two definite suggestions of the divine affinity of the soul, notably in the passage where he speaks of the

137 Bergk.

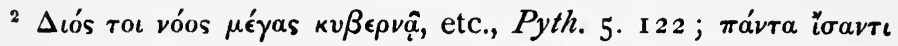
vów, ibid. 3. 29. See Buchholz, Sittliche Weltanschaunng d. Pind. u. Aesch. p. 24.

${ }^{3}$ Fr. 6 Bergk. 
mind's eye as seeing clearly during sleep, whereas in the day men see not the future:

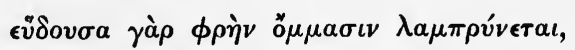

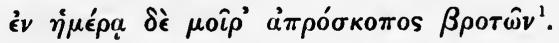

The notion underlying this passage, and I think also a passage in the Agamemnon ${ }^{2}$, is the same as we have already found in the fragments of Pindar and Aristotle. In sleep the soul is to a certain extent released from the shackles of the body, and foresees the future by virtue of her natural affinity with the gods. In harmony with this conception, Aeschylus attaches great weight to revelation by means of dreams; and even when the body is awake, in moments of ecstatic elevation, such as he portrays in the person of Cassandra, and in those dim forebodings of futurity that so often haunt the mind of the Chorus in the Oresteia, the soul appears to give proof of her connexion with the divine. Nowhere in Aeschylus, however, is this doctrine brought into relationship with the belief in immortality, as it is by Pindar; nor, indeed, except in recognising a judgment and punishments -never, I believe, rewards-hereafter, and in one or two further details, do the eschatological pictures of Aeschylus differ very much from those in Homer, except that the all-pervading gloom is deeper and more intense. With regard to Sophocles, I will only say that although Dronke has rightly called

1 Eum. $104 \mathrm{f}$.

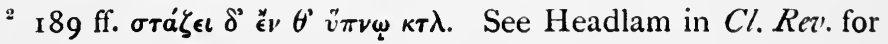
I 903 , p. $24 \mathrm{I}$. 
attention to certain exquisite touches of religious mysticism in his plays, for example ả $\nu \tau i$ $\mu \nu \rho i \omega \nu ~ \mu i ́ a \nu$ $\psi v \chi \eta^{\prime} \nu^{1}$, the particular subject we are now discussing cannot be illustrated from him. With Euripides the case is different, and we shall find that the form in which he expresses the idea of the soul's divinity is of the highest interest and importance in connexion with later philosophical thought in Greece. But before we speak of Euripides himself, it is necessary to say something about the sources of that distinctive type of theology with which in his plays and fragments the notion of man's relationship to God is associated.

In the age of Euripides, the concept of a creative or world-forming Nous or Reason had been made familiar to Greek thought by Anaxagoras' epoch-

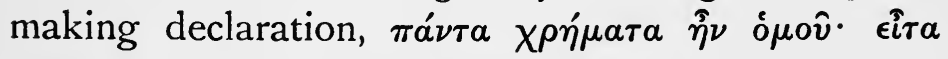

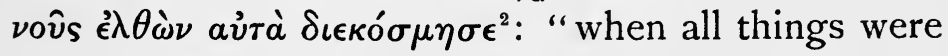
together, Reason came and set them in order." Whether the creative $\nu$ vis of Anaxagoras was a purely incorporeal or as we should say spiritual substance or not, is a question still debated; but this much at least is clear, that if it was corporeal, the material of which it was composed differed so much from every other kind of matter that it did not deserve to be called matter at all. To call it by the question-begging epithet of "thought-matter" or "thought-stuff," as Windelband does, throws no light upon its nature, besides being in my judgment a forced and unnatural translation of the Greek

${ }^{1}$ O. C. $49^{8}$.

${ }^{2}$ ap. Diog. Laert. II. 6. 


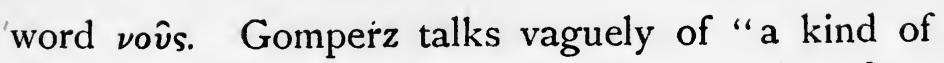
fluid or aether," a "curious reasoning fluid," "of an extremely refined and mobile materiality." Every such suggestion appears to me incompatible with the well-known criticism in the Phaedo, where Plato characteristically blames Anaxagoras, because after announcing that Mind is the cause of everything, he made little or no use of this great principle in explaining the constitution of the Universe, but had recourse to "airs and aethers and waters and many other such absurdities"." The opposition in this passage between Nous on the one hand, and the "airs and aethers" on the other, tells strongly against the identification of Nous with any substance of the kind; and, indeed, according to Anaxagoras himself, air and aether are among the substances which Nous originally separated off from the primeval mixture or chaos $^{3}$. It is impossible fully to discuss the matter here: I will only say that I agree with Heinze ${ }^{4}$ and Arleth $^{5}$ in holding that Anaxagoras probably intended us to understand by Nous an incorporeal essence, although in the absence of an accepted philosophical terminology he failed to make the new idea absolutely clear. There are still two points in connexion with Anaxagoras' theory of which my subject requires me to remind

${ }^{1}$ Greek Thinkers (E.T.), I 2 16, 1217.

2 Phaedo $98 \mathrm{c}$.

${ }^{3}$ Fr. 2 Diels (Frasmente der Vorsokratiker).

- Ueber d. Nov̂s d. Anaxagoras (Leipzig, 1890).

'Archiv f. Gesch. d. Philos. vin. 46 I ff. 
you. The world-ordering Reason which he describes is transcendent rather than immanent, although its immanence in certain things is not denied: $\boldsymbol{\epsilon}^{\sigma} \sigma \iota \nu$

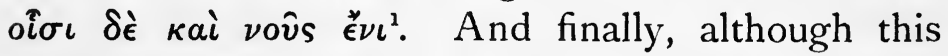
Nous possesses many of the attributes and discharges many of the functions which later philosophy ascribed to the Deity, Anaxagoras in his extant fragments nowhere calls it God.

Turn now for a little to the fragments of Diogenes of Apollonia, who lived in Athens during the latter part of the fifth century B.C., and whose philosophy is in effect little more than a revision of the physical theory of Anaximenes in the light of Anaxagoras' theory of Mind. The primary substance, says Diogenes, of which all other things are only particular forms or differentiations, is "great and strong and eternal and immortal and

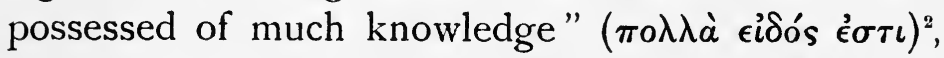
being able "to preserve the measures of all things, winter and summer, night and day, rains and winds and sunny weather"." "By means of Air," he says in another fragment, "all are steered and over all Air has power. For this very thing seems to me

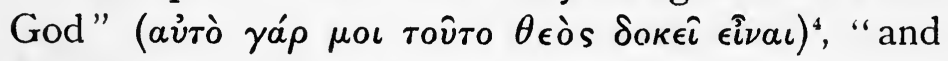
I believe that it reaches to everything and disposes everything and is present in everything.... There are many forms of living creatures many in number, resembling one another neither in appearance nor in way of life nor in intelligence owing to the
1 Fr. I I Diels.
${ }^{2}$ Fr. 8 Diels.
${ }^{3}$ Fr. 3 Diels.

$4 \theta$ cós is Usener's certain emendation for "̈̈os. 
multitude of differentiations; but yet they all live and see and hear by virtue of the same element, and all of them too derive their intelligence from the same source"." The Air within us, that is, our reason, Diogenes called a "little part of God"

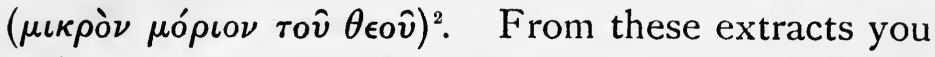
will see in the first place that Diogenes materializes the $\nu$ ovs of Anaxagoras in the element of Air: secondly, that he expressly identifies this noetic Air

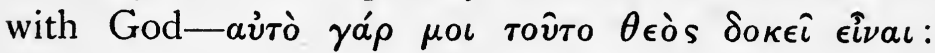
and thirdly, that this divine noetic Air is not transcendent, but only immanent-an all-pervading cosmic Deity, like the dóyos of the Stoics.

I have treated thus briefly of Anaxagoras and Diogenes not so much on their own account, as because of the light which they throw on certain highly characteristic passages of Euripides. The ancients were fond of calling Euripides the "philosopher upon the stage." Browning, I think, shews truer insight when he makes him say,

"I incline to poetize philosophy";

and it is with this poetical interpretation of the doctrine of Diogenes that I now proceed to deal. In discussing poetry, more especially dramatic poetry, we must of course be mindful of Browning's indignant protest,

"Which of you did I enable

Once to slip inside my breast,

There to catalogue and label

What I like least, what love best?'

${ }^{1}$ Fr. $5 . \quad{ }^{2}$ Diels $^{2}$ p. 33r. 3. 
No ancient poet has suffered so much as Euripides both in his own lifetime and afterwards from the vulgar species of gallery criticism that hisses the stage-villain. I may nevertheless be allowed to express my personal belief that the passages about to be discussed reflect a tone of feeling peculiarly congenial to the great poet of humanity, for a reason which will afterwards appear.

Let us now consider some of the passages in question. We have seen that Diogenes. identifies the all-pervading Air with God. To this theory Euripides has an allusion in the famous prayer of Hecabe in the Troades ${ }^{1}$ :

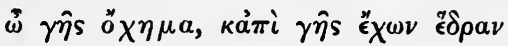

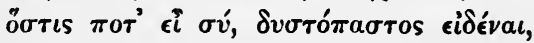

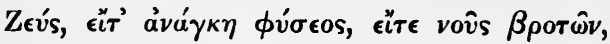

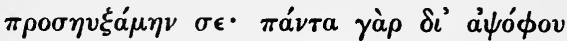

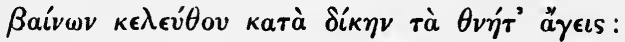
"O Earth's upholder, throned upon the Earth," etc. :

for Anaximenes, the philosophical master of Diogenes, taught that the earth "rides upon the air"

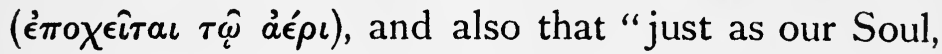
which is Air, holds us together, so also breath and Air encompass the whole Universe." You will remember that Plato, too, in speaking of this theory, compares the Air to a $\beta a^{\prime} \theta \rho \nu \nu$ or pedestal supporting the earth ${ }^{3}$. For the most part, however, when Euripides writes in this vein, it is Aether and not Air which he calls Zeus. In a poet, of course,

$1884 \mathrm{ff}$.

2 Diels p. $22 \$ 6,25 \$ 2$.

3 Phaedo 99 в. 
we ought not to expect a clear distinction between these two concepts, although Anaxagoras had already differentiated them. Euripides, no doubt, prefers the word "Aether" partly as having a greater wealth of poetical and religious associations than "Air." Thus in one fragment ${ }^{1}$ we read

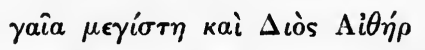

"Mightiest Earth and Aether of Zeus";

that is, I believe, not Aether "home of Zeus," though Euripides sometimes describes the element in that way, but just "Zeus's Aether," the Aether in which Zeus consists, the Aether of which Zeus is made, in no respect different from Zeus himself. The remainder of the fragment clearly shews that Zeus is here identified with Aether. "Aether," continues the poet, "is the father of men and gods ; and Earth receives into her womb the falling rain of dewy drops, and bears mortal men, aye, and food, and the tribes of wild beasts." But the most characteristic example in Euripides of this identification is contained in the well-known lines :

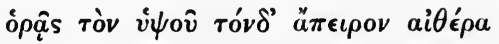

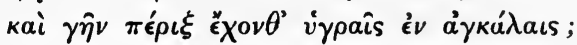

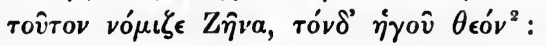

thus translated by $\mathrm{Mr}$ Way:

"Seest thou the boundless ether there on high

That folds the earth around with dewy arms?

This deem thou Zeus, this reckon one with God."

$1839 \mathrm{Nauck}^{2}$.

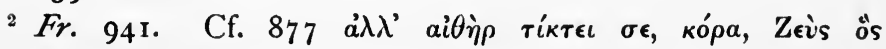

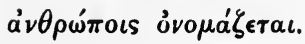


There is more than a touch of what W. K. Clifford called "cosmic emotion" in these verses. Nowhere, however, does ancient literature furnish a more perfect expression of cosmic feeling or a finer example of the poetical treatment of a philosophical conception than we meet with in a less known fragment of Euripides descriptive of the aetherial creative reason indwelling in the world:

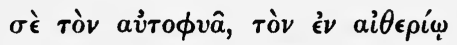

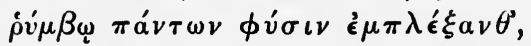

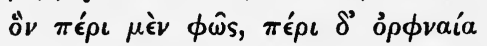

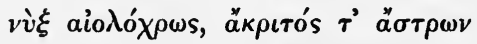

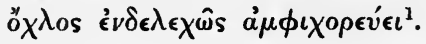

"Thee, self-begotten, who in ether rolled

Ceaselessly round, by mystic links dost bind

The nature of all things, whom veils enfold

Of light, of dark night flecked with gleams of gold,

Of star-hosts dancing round thee without end."

$\mathrm{Mr}$ Way, to whom this translation is due, justly compares the familiar lines of Wordsworth :

\section{"I have felt}

A presence that disturbs me with the joy

Of elevated thoughts; a sense sublime

Of something far more deeply interfused,

Whose dwelling is the light of setting suns,

And the round ocean, and the living air,

And the blue sky, and in the mind of man:

A motion and a spirit that impels

All thinking things, all objects of all thought, And rolls through all things."

We may say, I think, that in this all-pervading spirit, "the soul of all the worlds," as he sometimes 
calls it, Wordsworth finds the true and essential unity of Nature-it embraces, as Euripides would have said, the "nature of all things,"

"Even as one essence of pervading light

Shines in the brightest of ten thousand stars

And the meek worm that feeds her lonely lamp

Couched in the dewy grass."

The parallel between Euripides and Wordsworth is here complete; and in Virgil, too, we have exactly the same conception :

deum namque ire per omnes terrasque tractusque maris caelumque profundum ${ }^{1}$.

Some may be disposed to call this philosophy, others will call it poetry, and others, perhaps, religion; but in truth it is only one particular way of trying to express that omnipresent unity which poetry and religion make us feel, which science also presupposes, and which it is perhaps the ultimate goal of a philosophy of the sciences-Plato, at least, believed it was-to demonstrate and apprehend. But to return. I think it is deserving of particular notice that in each of the three poets I have named, this kind of poetical pantheism, or Naturemysticism, as it may more appropriately be called, is accompanied not only by a deeper sense of the unity between man and nature, but also by a profounder sympathy with "human weal and woe" than we readily find elsewhere. It was a true instinct that prompted Tennyson to put together in

Georgics 4. 221 f.: also in Aeneid 6. 724 ff.

A. E. 
a single stanza these two characteristics of Virgil's poetry :

"Thou that seest Universal

Nature moved by Universal Mind;

Thou majestic in thy sadness

At the doubtful doom of human kind."

The power inherent in Nature dwells also "in the mind of man," so that the link which binds us to the one unites us also to the other. You will remember that the later Stoics expressly founded their doctrine of human brotherhood on the presence

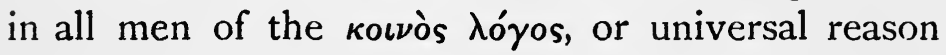
that "moves through all things, mingling with the great and lesser lights ${ }^{1}$." Marcus Aurelius, for example, reminds us that man's brotherhood with all mankind depends not on blood, or the generative seed, but on community in mind ( $\nu$ ô $\kappa o \iota \nu \omega \nu i ́ a)$ : each man's mind, he says, is God and an efflux

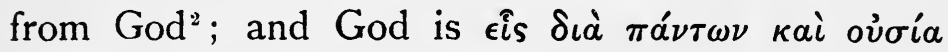
$\mu i a$, "one God, one essence stretching through all things ${ }^{3}$," present in Nature as well as in man. The humanism of Euripides is not an intellectual dogma, but the language of the heart; yet it is more than a mere accident-I would rather say it is the operation of a law of nature-that the most profoundly human of tragedians should have been the author of the greatest nature-drama of antiquity, I mean, of course, the Bacchae.

So far, I have spoken only of the peculiar kind

${ }^{1}$ Hymn of Cleanthes $12 \mathrm{f}$.

${ }^{2}$ XII. 26. 
of poetical theology which is sometimes found in Euripides. That which Pindar calls "the gods"-

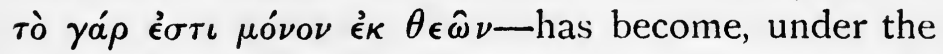
influence, perhaps, of Diogenes, an immanent, allembracing aetherial substance designated by the name of Zeus. Let us now turn from the divine to the human, and consider one or two of those passages in which the poet has in view the doctrine of man's affinity to God. The fragment most commonly cited by the ancients in this connexion is the line

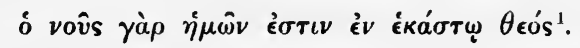

"The reason in each one of us is God."

Our first impression is that we have here the same sentiment as that of Dante, "Mind is that culminating and most precious part of the soul, which is Deity"." If we look closer, however, we shall see

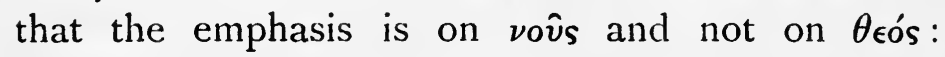
Euripides means there is no God but reason; and so the line was explained by Nemesius. This is not mysticism, but rationalism, in the sense in which the word is used in "Euripides the rationalist." In the prayer of Hecabe it is difficult to say whether

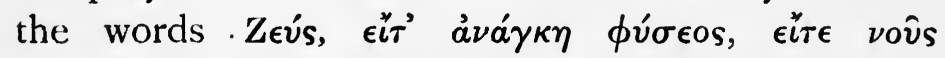
$\beta \rho о \tau \hat{\omega} \nu$ - "Zeus, whether thou art Nature's law or mind of man"-are meant to be understood in the rationalistic or in the mystical sense. Perhaps the latter interpretation is the more probable, seeing that Hecabe has already spoken of

1 Fr. 1ол8.

" Convito III. c. ii, tr. K. Hillard. 
Zeus in language suggested by the theory of Diogenes, according to which the mind of man is a form of that universally diffused aerial substance which Diogenes holds to be God. I do not think

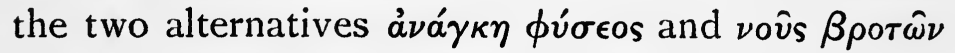
are intended to be rigidly construed; if Zeus, as Hecabe implies, is omnipresent Air or Aether, he is at once the law of Nature-an allusion, I think, to Democritus and the Atomists-and the mind of

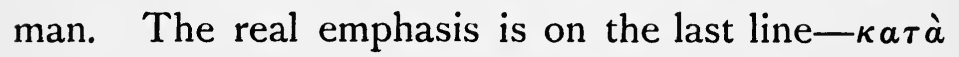
$\delta i \kappa \eta \nu \tau \dot{a} \theta \nu \eta^{\prime} \tau^{\prime} a ̆ \gamma \epsilon \iota s:$ "whatever Zeus may be, the sceptre of his kingdom," Hecabe means, "is justice." But interpret this passage as we may, the doctrine of the kinship between the mind of man and the cosmic mind or aether is clearly involved in two lines of the Helena. The speaker is Theonoe, to whose character, as $\mathrm{Mr}$ Pearson says, "an element of mysticism is appropriate."

\section{o vov̂s}

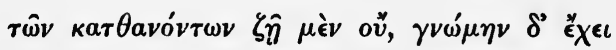

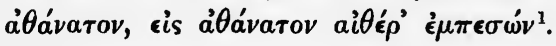

\section{"Albeit the mind}

Of the dead live not, deathless consciousness

Still hath it, when in deathless aether merged $^{2}$."

Here, of course, we have nothing but a highly philosophised interpretation of the idea underlying the well-known fifth-century epitaph on the Athenians who fell at Potidaea: "Aether received their souls, and earth their bodies: by the gates of Potidaea

${ }^{1}$ Hel. ror $4 \mathrm{ff}$.

"Way's translation (substituting "mind" for "soul"). 
they were slain"." In the background there is the theory, derived, no doubt, from Anaxagoras, that absolute creation and absolute destruction have no place in the economy of nature; the phenomena we call life and death are only the temporary union and subsequent dissolution of pre-existing and imperishable elements. The bearing of this theory on anthropology is thus expressed by Euripides in a fragment to which I have already referred: "All things go back whence they came: that which was born of Earth to Earth, and that which sprang from the seed of Aether returns to the firmament of Heaven"." You will further notice that in Euripides it is not, as in the epitaph, $\psi v \chi \dot{\eta}^{\prime}$, but $\nu$ ovs, that returns to the aetherial element. Elsewhere, in agreement with Epicharmus (if the fragments are really by Epicharmus ${ }^{3}$ ), he calls the divine element in man-the element that rejoins the aether-by the name of $\pi \nu \epsilon \hat{v} \mu \alpha$,

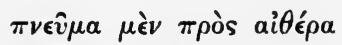

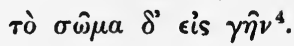

It is interesting in this connexion to observe that each of these two terms, $\nu$ ovs and $\pi \nu \epsilon \hat{v} \mu a$, occupies a somewhat analogous position not only in the psychology of Stoicism, but also in the writings of St Paul, according to whom the highest part of us, the $\pi \nu \epsilon \hat{v} \mu \alpha$, "is what it is by virtue of its affinity to God"," "an element," as Dr Swete has said, "corre-

\footnotetext{
1 C.I.A. I. $44^{2}$.

${ }^{3} 245,265$ Kaibel.

2 Fr. 839.

4 Suppl. $533 \mathrm{f}$.

${ }^{5}$ Sanday and Headlam, Romans, p. r96.
} 
sponding to the Divine Spirit and fitted to be the sphere of His operations "," while vovs, in the words of another theologian, is in St Paul just " the $\pi \nu \epsilon \hat{v} \mu \alpha$ operative as a faculty of knowledge directed toward Divine things"." In Euripides, perhaps, it may be doubted whether $\pi \nu \epsilon \hat{v} \mu a$ really means much more than "breath"; but vov̂s certainly does, and in this respect there seems to me a real analogy between the Greek and Christian thinker. Still more characteristically philosophical is the distinction which the poet here draws between life and consciousness. The mind, when reabsorbed in aether, no longer lives, that is to say, it has no personal or individual existence, but it nevertheless shares in the consciousness belonging to the universal spirit. The passage we are now discussing is, I believe, the earliest explicit affirmation in Greek literature of the kind of cosmic immortality which Aristotle

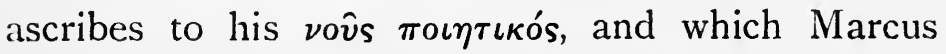
Aurelius also had in view when he wrote the words: "You will disappear in him who gave you being; or rather you will be changed and reabsorbed into his generative reason" ( $\mu \hat{a} \lambda \lambda o \nu \delta \dot{\epsilon} a \dot{\nu} a \lambda \eta \phi \theta \dot{\eta} \sigma \eta \underline{\epsilon}$ is

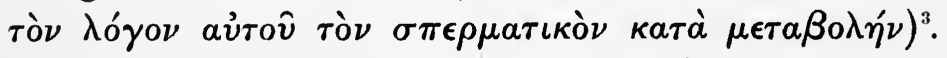
The ethical and religious value of this conception depends on the extent to which it emphasises the prospect of reunion with the divine, rather than the consequent extinction of our individuality. To what heights of almost ecstatic enthusiasm it could

${ }^{1}$ Hastings, Dictionary of the Bible, II. p. 409 a.

${ }^{2}$ Findlay in Hastings, l.c. III. p. 720 b. $\quad{ }^{3}$ IV. I 4. 
sometimes lift the poet may be seen from an extraordinary fragment which would probably have been denounced as a Neoplatonic forgery, if it had not been referred to by Plutarch as well as quoted by Clement: "Upon my back sprout golden wings : my feet are fitted with the winged sandals of the Sirens: and I shall soar to the aetherial firmament to unite with Zeus" $-Z \eta \nu i \pi \rho \circ \sigma \mu \epsilon i \xi \omega \nu^{1}$. I think it probable that Zeus in this fragment stands for the

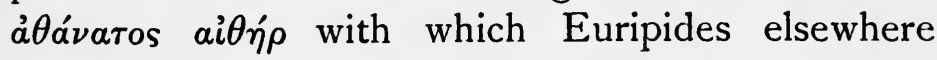
identifies the god.

In an exhaustive discussion of Euripides' treatment of the subject before us, we should have to take account of many other passages, and particularly of those in which he alludes to the Orphic and Pythagorean view that the body is the prison-house or tomb of the soul : $\sigma \hat{\omega} \mu a \sigma \hat{\eta} \mu \alpha^{2}$. But it is preferable, I think, in what remains of my allotted time, to draw your attention, first, to one or two traces of the doctrine of the soul's divinity in the discourses of the historical Socrates, and afterwards to the part which this doctrine plays in the philosophy of Plato.

The central idea of Socrates' teaching has justly been called Noocracy; what he desired above all things to establish was the rule of Reason alike in the individual and in the state. In like manner, according to Xenophon, he sometimes represented the Godhead as the reason or wisdom indwelling

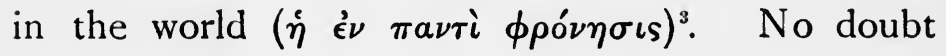
1 Fr. 9 I 1.
${ }^{2}$ Fr. 638, 833 .
${ }^{3}$ Mem. I. 4. I 7 . 
Socrates himself developed the notion on practical rather than theoretical lines, using it as a motive to encourage piety, by dwelling on the unwearied zeal with which this cosmic intelligence consults the interests of man-for his teleology is almost painfully anthropocentric; but there is none the less a real analogy between the Socratic conception and the philosophical theory we have been discussing. And in at least one passage of the Memorabilia Socrates definitely suggests that the human mind is itself only a portion of the world-informing Reason, which, according to Xenophon, he occasionally identified with God. Xenophon is relating a conversation between Socrates and Aristodemus, and has reached the point at which the young man, though originally disposed to ridicule the belief in gods, is constrained to allow that there is some little force in the argument from design. "Well now," says Socrates, "do you suppose that you have a little wisdom yourself, and yet that there is no wisdom to be found elsewhere? And that, too, when you know that you have in your body only a small fragment of the mighty earth, and a little portion of the great waters, and of the other elements, extending far and wide, you received, I suppose, a little bit of each towards the framing of your body? Mind alone, forsooth" - $\nu \circ \hat{v} \nu \delta \hat{~} \dot{a}$ ă $\rho a$

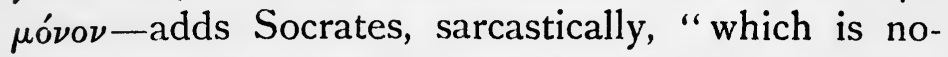
where to be found, you seem by some lucky chance or other to have snatched up from nowhere'." In

${ }^{1}$ Mem. I. 4. 8. 
its full significance, the implication contained in this concluding sentence is that the soul or rather the mind ( $\nu$ vos) of man is, as the Stoics said, a fragment or ámó $\sigma \pi a \sigma \mu a$ of the universal mind or God; but the doctrine is not elsewhere touched upon by the Socrates of the Memorabilia, at least in this particular form, although there is one other passage where he pronounces the soul to be divine'.

The speech of the dying Cyrus in the Cyropaedia of Xenophon supplies some additional examples of the type of thought which I am trying to illustrate, and in particular makes the doctrine of the divinity of soul into an argument for immortality and divination. In words that irresistibly recall the Phaedo of Plato, Cyrus expresses a disposition to believe that the soul, or rather the vovis or reason, survives the moment of death, and being then pure and uncontaminated by communion with the body-

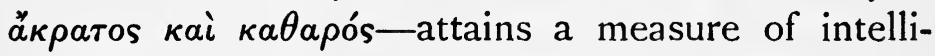
gence far beyond what it has hitherto enjoyed. When the body dissolves, its component factors, Cyrus says, return to the elements with which they are akin; and what of the soul? We cannot see it as it passes, but neither do we see it while it animates the body. Presumably therefore-this we are left to infer-the soul likewise, in virtue of its divinity, returns to the divine. Yet another reason is given by Cyrus for supposing that our intelligence is heightened after death. In sleep, which is the image and counterpart of death, the soul most 
fully realises its kinship with the Godhead, and penetrates the veil that usually hides from us the future; and the explanation is that during sleep more than at any other time the soul is freed from the dominion of the body ${ }^{1}$. For the origin of these and similar views, which only make explicit what is already implicit in the fragment of Pindar, we must doubtless look to the Pythagorean doctrine of the body as the sepulchre of the soul; but what I wish to suggest is that it is perfectly possible-for my own part I think it highly probable-that the historical Socrates sometimes conversed in this way. The Cyropaedia is permeated, of course, by Socratic ideas; and in this instance the parallel between Xenophon and Plato is in favour, so far as it goes, of the presence in their common master of a similar strain or tendency of thought. Nor are such ideas otherwise than in harmony with the temperament of Socrates. Although no one ever served the cause of Reason better, he was not, in any narrow acceptation of the word, a "rationalist" pure and simple. His susceptibility to the influence of dreams, attested both by Xenophon and Plato; his faith in oracles; those frequent "pauses of immobility," during which he would stand for hours together, as Gellius says, "inconnivens, immobilis, eisdem in vestigiis, tanquam quodam secessu mentis atque animi facto a corpore" ${ }^{2}$; and, above all, the divine sign or "voice," the pledge and symbol of his intimate relationship to God-for these and 
other features we must seek analogies in the history, not of rationalism, but of religion. It is impossible, I think, to understand the historical Socrates without taking account of the religious as well as of the rationalistic elements in his character; but the link that unites the two is contained in the doctrine that

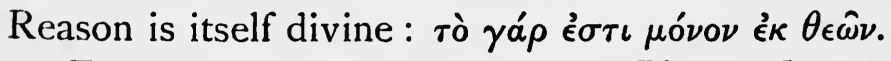

From Socrates we now pass to Plato. It would require a treatise to give any adequate idea of the extent to which this doctrine penetrates nearly the whole of Plato's teaching from beginning to end of his long career, and I can hardly even attempt to shew you how, beyond all other Platonic doctrines, it has made Platonism live throughout the ages, not only in poetry, philosophy, and theology, but also, perhaps, in human lives. The most that I can do is to mention one or two different ways in which Plato expresses his belief in man's affinity with the divine, and to indicate a few of the principal implications of the theory in Platonism, with some remarks on its connexion with later religious and philosophical thought.

The nearest analogy in Plato to the kind of cosmic deity of earlier and later Greek philosophy is of course the soul of the world in the Philebus ${ }^{1}$ and Timaeus ${ }^{2}$ : but in Plato, I need hardly say, the world-soul differs from the immanent Godhead of Diogenes and the Stoics, inasmuch as it is a purely immaterial or spiritual essence. In the Philebus Plato derives the human soul from the soul of the

$$
{ }^{1} 28 \mathrm{c} \mathrm{ff} \text {. }{ }^{2} 34 \mathrm{c} \text { ff. }
$$


world; and the train of reasoning by which he supports this derivation is only a more developed and expanded form of the argument employed by Socrates in his conversation with Aristodemus ${ }^{1}$. But the conception of a cosmic soul, at least in this particular shape, is absent from the earlier dialogues of Plato; and even in the Timaeus the human soul, or rather the rational and noetic part of it, is not, as in the Philebus, dependent for its origin upon the soul of the world, but, like the world-soul itself, comes directly from the supreme God or Demiurgus. "As concerning the sovereign part of soul within us," says Plato, "that which we say, and say truly, dwells at the top of the body and raises us from earth towards our heavenly kindred, forasmuch as

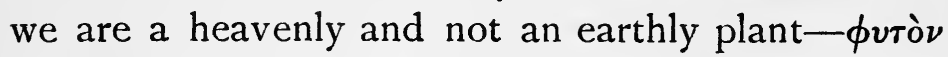

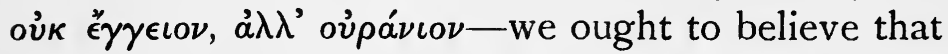
God has given it to each of us as a daemon"," that is, a genius or guardian angel to direct our lives, in the beautiful phrase of Menander, as it were our $\mu v \sigma \tau a \gamma \omega \gamma$ òs $\tau o \hat{v} \beta \iota_{0 v}^{3}$. It is in this passage, I believe, that we should seek the origin of the view so much insisted upon by the later Stoics, that the faculty of reason, to quote the words of Marcus

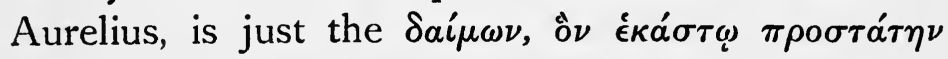

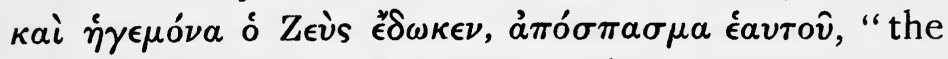
genius, which Zeus has bestowed on every man, to

129 A ff.

2 Tim. 90 А.

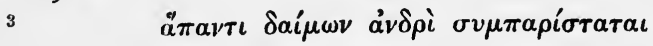

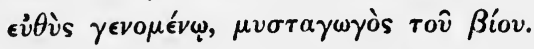

Meineke Iv. p. 238. 
be a ruler and guide, even a fragment of himself ${ }^{1}$." In other Platonic dialogues the form of expression is metaphysical rather than theological, though here, too, owing to the characteristically Platonic fusion of theology and metaphysics, there is still a certain colouring of theology, or perhaps I had better say, religion. In the Republic the soul in its essential, that is, its rational nature, is said to be "akin to the divine and immortal and ever-existent ${ }^{2}$," that is to the changeless and eternal essence which Plato calls the Ideas; and in the Phaedo we read that whenever the soul-and by the soul in this dialogue he means vovs-whenever the soul makes use of the body and its senses in any investigation, "she is dragged by the body into the region of the changeable, and like the objects she is fain to grasp, this way and that she wanders, confused and dizzy like a drunkard. But when she investigates a subject by herself, away she soars into the realm beyond, to join the pure and eternal and immortal and unchangeable, and, because she is of their kindred, with them she ever dwells as often as it is permitted her to be alone; and then she no longer wanders, but changes not, because she is in contact with the changeless ${ }^{3}$." You will see from this passage that although the doctrine of the soul's celestial origin has now been intellectualised, its religious meaning is not yet lost. For the nearest parallel to such passages of Plato, and they are very numerous, we must look to the Paradiso of Dante. "Thou

$$
\text { I v. } 27 . \quad 2611 \mathrm{k} . \quad 379 \mathrm{c} \mathrm{ff} \text {. }
$$


shouldest know," says Beatrice, "that all have their delight in proportion as their sight sinks deep into that Truth wherein every intellect finds rest ${ }^{1}$."

I say no more at present about the manifold ways in which the infinite variety of Plato's genius gives expression to the old Pindaric sentiment, rò

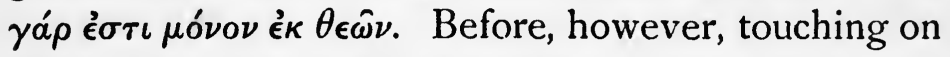
the applications of the doctrine in Platonism, let me call your attention to a new and historically fruitful idea with which Plato enriches this ancient belief. The question as to the essential meaning of the word man-what it is in virtue of which we are said to be human-had hardly as yet been raised by Greek philosophy. In the view of Plato, it is just the presence of this divine element that makes us specifically human. Man is most truly man when he most resembles God. This suggestion is clearly intended in two passages of the Republii. The first is where Plato is describing how the true legislative artist will endeavour to model the character and lives of men after the image of the divine. Looking now at natural, that is, ideal-observe how the natural in Plato is always the ideal-Beauty and Justice and Temperance, and now at the actual picture he is painting, he will, says Plato, blend and mingle institutions, like so many colours, until he has obtained tò à $\nu \delta \rho \epsilon i \kappa \epsilon \lambda o \nu$, the colour and complexion of true manhood; and he will found his idea of the $\dot{a} \nu \delta \rho \epsilon i \kappa \epsilon \lambda o \nu$ on that which, when it appears among men, Homer himself called $\theta \epsilon o \epsilon \iota \delta \epsilon^{\prime} \tau \epsilon \epsilon a i$

\footnotetext{
1 Canto 28. $106 \mathrm{ff}$.
} 
$\theta \epsilon о \epsilon i \kappa \epsilon \lambda o \nu^{1}$. The Manlike, in short, is the Godlike. The second passage occurs in the elaborate comparison of human nature as it now is to a kind of chimaera or triple-headed creature, wearing the vesture of humanity, and comprising within its folds a many-headed monster, symbolical of desire, a lion, symbolical of spirit, and withal what Plato, in language made familiar to us by St Paul, declares to be the "inward man" ( $\dot{o}$ évròs ă $\nu \theta \rho \omega \pi o \varsigma)$, in other words the vov̂s or Reason. What account, then, Plato asks, shall we give of virtue? We will say that virtue consists in bringing the bestial elements-the lion and the ape-into subjection to the human, "or rather," he continues, "shall

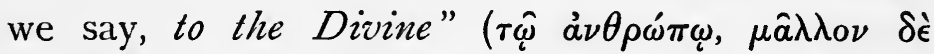
$\ddot{i} \sigma \omega s-\tau \hat{\omega} \theta \epsilon i \omega)^{3}$. The suggestion that man is truly human just in proportion as he is divine was afterwards taken up by Aristotle and the Stoics ${ }^{4}$; and no one can fail to see its hitherto unexhausted, perhaps for ever inexhaustible, significance in religion. "It would seem," says Aristotle, "that this"-meaning the divine or rational part of man

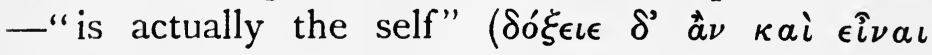

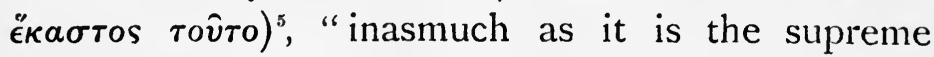
and better part of man." The implication in the

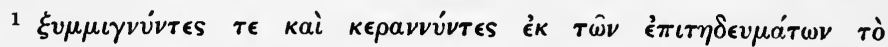

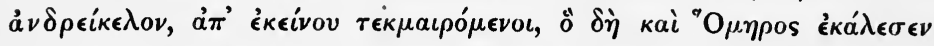

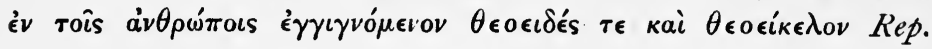
$50 \mathrm{I} \mathrm{B.}$

\footnotetext{
$5^{89} \mathrm{~A}$. ${ }^{3} 5^{89} \mathrm{D}$.

4 See (for the Stoics) e.g. Marc. Aur. xir. 3.

${ }^{5}$ Eth. Nic. x. 7. 9.
} 
epithet "better," that the good alone is the truly existent, is not less Platonic than the pregnant and powerful phrase in which the pupil of Plato points the moral lesson of this and all his master's teaching :

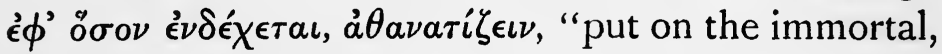
as far as in thee lies."

Consider now some of the implications of this theory in Platonism. Since man is by nature akin to the divine, the end and object of his existence must of necessity be $\delta \mu o i \omega \sigma \iota s \tau \hat{\omega} \theta \epsilon \hat{\varphi}$, " assimilation to God": the fullest possible realisation in this mortal life of that immortal nature which alone can truly be called our own. The doctrine of $\delta \mu o i \omega \sigma \iota s$ $\tau \hat{\omega} \theta \epsilon \hat{\omega}$ plays a conspicuous part in the teaching of Plato. "It is God," he says in the Laws", "and not, as some have asserted, man, who ought to be to us the universal measure or standard." This is the dominating motive throughout nearly the whole of Plato's polemic against Homer in the second and third books of the Republic: the Homeric gods are to be discarded because they do not provide a moral ideal for mankind-Euripides, you remember, had the same idea, and so had Xenophanes before him: and this is also the principle of the reformed theology which Plato is desirous of inaugurating in his ideal state. In its political application, the $\delta \mu i^{\omega} \omega \iota \iota s \in \hat{\omega}$ means the establishment of a kingdom

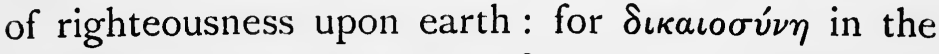
Republic is not really a specific virtue, but righteousness, the root and source of all the individual 
virtues, the virtue about which Aristotle ${ }^{1}$, quoting a fragment of Euripides", says that "neither the morning nor the evening star is so beautiful." Plato in the Republic is looking for a civitas deinew heavens and a new earth, 'é ois $\delta \iota k a \iota \% \sigma \dot{\nu} \nu \eta$ катокк $\hat{\imath}^{3}$ : and indeed, as the argument unfolds itself, we behold the originally "Hellenic city" gradually changing into a celestial commonwealth,

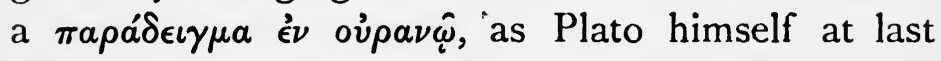
confesses it to be.

If we limit our survey to the progress towards perfection of the individual man-and in Plato political is always founded upon private virtuewe may say, I think, that the realisation by the individual of his true and immortal nature is described by Plato from three main points of view. In the Phaedo it appears as the $\mu \in \lambda \epsilon \operatorname{t\eta } \theta a \nu a$ rov, the "study" or rather "rehearsal of death," the mortification of our lower nature for the sake of reviving the higher, dying, in short, that we may live. The germ of this conception is of course much older than Plato, as he himself points out. I will quote a single illustration from Heraclitus. "Both living and dying are present in our life and in our death ; for when we live our souls are dead and buried in us, and when we die our souls revive and live."." And the Orphic and Pythagorean religious discipline was already to a certain extent a practical illustra-

1 Eth. Nic. v. I. I 5.

32 Pet. iii. 13.

${ }^{2} 490$ Dindorf : cf. Nauck ${ }^{2} 486$.

4 Rep. 470 E, 592 в.

${ }^{5}$ ap. Sext. Emp. Pyrrh. 111. 230.

A. E. 
tion of the Platonic precept. You will observe, however, that in the fragment of Heraclitus "we" means rather the body than the soul, whereas in Plato, as we have seen, the true personality is the

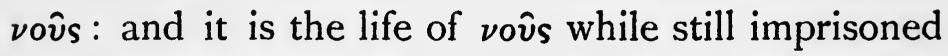
in the body that the Platonic meditatio mortis is intended to resuscitate. The soul of the lover of wisdom, says Plato, "withholds herself from pleasures and desires and pains and fears so far as she is able"; for she knows that every new indulgence will add to the chains from which she longs to be released $^{1}$. We must fly away yonder, far from the world of sense and sensual things: $\chi \rho \grave{\eta} \epsilon^{\epsilon} \nu \theta \epsilon \dot{\nu} \delta \epsilon$

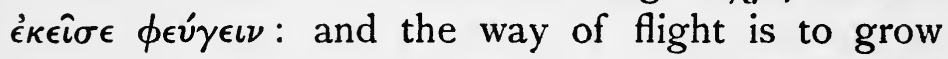
like unto God in righteousness, holiness, andobserve the characteristic addition-in wisdom ${ }^{2}$.

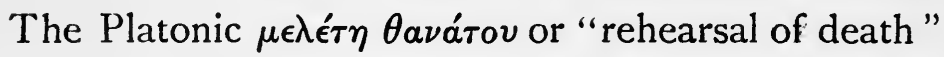
has often been compared with the Pauline doctrine of Necrosis, but the parallel deserves, I think, an even closer examination than it has yet received. There is hardly any subject of investigation which invites and permits one to turn so clear a light upon the points of contrast as well as similarity between Platonic and Pauline thought. One such contrast lies in the predominantly intellectual or rather noetic character of the aspiration expressed in Plato's " rehearsal of death." I say predominantly intellectual, for it is by no means exclusively so. What Mr Nettleship has said of Greek philosophy in general is pre-eminently true of Plato. "We 
say that Greek moral philosophy, as compared with modern, lays great stress on knowledge and gives excessive importance to intellect. That impression arises mainly from the fact that we are struck by the constant recurrence of intellectual terminology, and omit to notice that reason or intellect is always conceived of as having to do with the good. Reason is to Greek thinkers the very condition of man's having a moral being.... Their words for reason and rational cover to a great extent the ground which is covered by words like 'spirit,' 'spiritual,' and 'ideal' in our philosophy. They would have said that man is a rational being, where we should say that he is a spiritual being." In this way, I believe, the life of Reason, in Plato, becomes not only intellectual, but also something akin to what is afterwards called spiritual life: for in Platonism, as the Cambridge Platonists were fond of saying, it is always Reason which is the "candle of the Lord." At the same time the contrast holds good, with the qualification that I have mentioned. A second and closely related point of difference between St Paul's

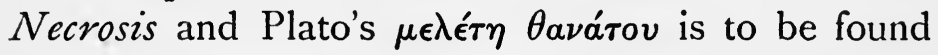
in the strain of asceticism in the Phaedo, though here again the exercise of vov̂s brings pleasures of its own, the truest and purest pleasures, Plato says; and Gomperz is right in saying that although Weltfucht touched the soul of Plato, it never enchained it. But the really fundamental contrast

1 Lectures and Remains, 11. p. 221. 
has already been pointed out by Matthew Arnold ${ }^{1}$. I will venture to put it in a single phrase of St Paul, a phrase that as if by the touch of some heavenly alchemy at once transforms a philosophy into a

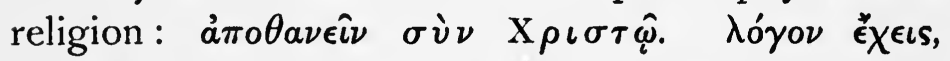

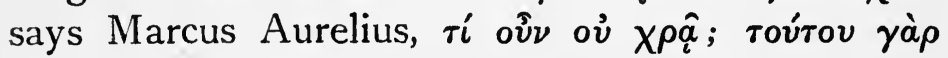

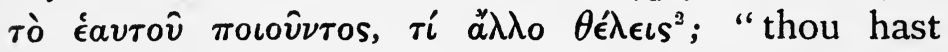
reason: why then not use it? If reason does its work, what else dost thou require?" St Paul's $\sigma \grave{\nu} \nu \mathrm{X} \iota \sigma \tau \hat{\omega}$ supplies the something else-the driving power which has made the Platonic $\mu \in \lambda \epsilon ́ \tau \eta \theta$ avárov an inexhaustible source of moral inspiration throughout the ages.

The second of the two aspects in which Plato represents this great idea is that which is developed in the Symposium and elsewhere. The object of adoration in that dialogue is not so much the primal Goodness, as the primal Beauty, the divine Beauty of which Plato says that it is ever-existent, alike uncreated and imperishable, knowing neither increase nor decay, beautiful always and everywhere and in all relations and respects; and all other things which we call beautiful are beautiful because they participate in it, yet in such a way that although beautiful particulars come into being and perish, the Ideal Beauty nevertheless suffers no diminution nor increase nor change of any kind at alls. The path of the soul in the Symposium leads upwards from the lovely things of earth to those of heaven; we

\footnotetext{
1 St Paul and Protestantism, p. 53, ed. 1889.

2 IV. I3.

s 2 II A f.
} 
should use the former as $\epsilon \pi \alpha \nu a \beta a \theta \mu o i$ or steppingstones, passing first from one to all fair bodies, next from corporeal beauty to the beauty of institutions and from institutions to sciences, until we arrive at the study of Ideal Beauty, and at last perceive the Beautiful in its true and essential nature ${ }^{1}$. "Suppose," concludes Diotima, "suppose it were granted to one to behold the Beautiful itself, pure and clear and unadulterated, not tainted by human flesh or colours which man has made, or any other of the countless vanities of mortal life, but the Divine beauty as it stands in its simplicity and isolation: do you think it would be an ignoble life that we should gaze thereon and ever contemplate that Beauty and hold communion with it? Or rather do you not think that in this communion only is it possible for a man, beholding the Beautiful with the organ wherewith alone it can be seen, to beget, not images of virtue but realities, for that with which he holds communion is not an image, but the truth, and having begotten and nourished true virtue to become the friend of God and be immortal, if ever mortal has attained to immortality2." The contemplation of the Ideal Beauty is in Plato life-nay more, it is

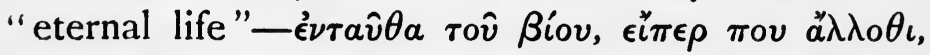

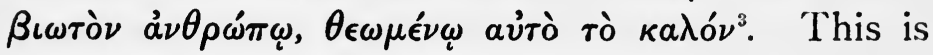
the side of Platonism which has appealed in all ages to the religious mystic, the poet, and the artist. Of its influence in religious mysticism, the Bampton lectures of $\mathrm{Mr}$ Inge will supply you with many
12 I I B f.
22 II D-2I2 A.
32 I I D. 
examples; in sculpture, its greatest exponent, perhaps, is Michael Angelo, whose sonnets also bear witness to the fervour of his Platonism; and in poetry, the central idea of the Symposium, expressed by one of the Cambridge Platonists in the lines

"All streams of Beauty here below Do from that immense Ocean flow, And thither they should lead again ":

in poetry, I say, this great conception inspires the whole of Dante's Divine Comedy, and finds fit utterance in many single passages of the Paradiso. "The leaves with which all the garden of the eternal Gardener blooms, I love in measure of the good transmitted to them from him.". And in another canto: "Behold now the height and amplitude of the Eternal Worth, seeing it hath made itself so many mirrors in which it breaks, while remaining one in itself, as before ${ }^{3}$." A more perfect expression of the essential content of Platonism is not to be found in the writings of Plato himself.

Thirdly, the ascent of the soul towards the fountain of her being is represented by Plato as an educational process-the pursuit of knowledge. This is unquestionably the most characteristic and fruitful point of view from which he regards the matter: indeed it is the point of view which ulti-

${ }^{1}$ John Norris (quoted by Harrison, Platonism in English Poetry, p. 86).

${ }_{2}^{2}$ Par. 26. $64 \mathrm{ff}$. Cf. especially Il Convito, iv. c. I2.

3 Par. 29. $142 \mathrm{ff}$. 
mately includes and embraces all the others. In every human creature, he holds, there is present from the first an organ whose preservation is of more importance than a thousand eyes: since by it alone Truth is seen". This faculty, "the vision and the faculty divine," it is the business of the educator to nurture and develop, not to instil into his pupils from without : for

\section{"to know}

Rather consists in opening out a way

By which the imprisoned splendour may escape

Than in effecting entry for a light

Supposed to be without."

The principle enunciated in these lines determines the whole of Plato's educational method and curriculum. In earlier years the object is to bring the mind into unconscious harmony with the beauty of reason through the influence of Poetry and Art, the proper function of which, in Plato's way of thinking,

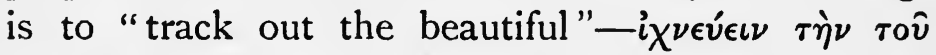
$\kappa a \lambda o \hat{v} \phi \dot{v} \sigma \iota \nu^{2}$-as it is manifested in nature, in the human form, and in the works and characters of men, and embody this and this alone in the material with which they deal. Later, when the reasoning powers begin to awaken, the discipline becomes severely intellectual, only such studies being admitted as are able, in Platonic phrase, to purge and

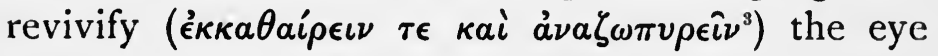
of the soul : but Plato is careful to insist that the rational faculty can never be turned from darkness
${ }^{1}$ Rep. 527 E.
2 Rep. 401 c.
${ }^{3}$ Rep. 527 D. 
to light unless the whole nature of the man is turned along with it; and one of the incidental results of the higher curriculum is to strengthen the moral discipline of youth by disclosing the bed-rock of reason on which it was founded. In the truly philosophic nature, according to Plato, it is the amor intellectualis, the passion for truth, not this or that portion of truth, but all truth, everywhere and always, that is the source of all the moral virtues too-courage and high-mindedness, temperance, justice, kindness and the rest ${ }^{1}$. In the last analysis, morality, in Plato, is the love of Truth. By the ladder of the mathematical sciences, or as Plato is already beginning to call them, "arts"-in this originating, as I have elsewhere tried to shew, our modern academic usage of the word-the mind slowly and laboriously climbs upward into the kingdom of realities; for we must get behind and above mathematics, behind every other single science, if we are really to attain to knowledge, as the word is understood by Plato. To this elevation we rise by what he calls Dialectic, in the view of Plato the science of sciences, above and beyond all other sciences, even as its final object, the Idea of the Good, determines all the other Ideas. If we may try to interpret Plato's dream in something like the language of to-day, and it is a dream which is a little nearer to fulfilment now than in his time, we may say, perhaps, that the ultimate goal of knowledge is not even then attained when each 
particular science has at last combined and correlated its several classes of phenomena under adequate generalisations and these again under one supreme generalisation which will constitute the $\dot{\alpha} \rho \chi \eta^{\prime}$ or first principle of the science. Something more than this is needed, something like the ideal which a recent writer had in view when he suggested that "in another age, all the branches of knowledge, whether relating to God or man or nature, will become the knowledge of 'the revelation of a single science,' and all things, like the stars in heaven, will shed their light upon one another ${ }^{1}$." The first principles of the several sciences must in their turn be correlated with one another and themselves subsumed under the first principle of all, which in Plato is the Good. It is only then that the philosopher becomes "a spectator of all time and all existence," only then that he recognises the essential unity of knowledge and understands in the fullest senseobserve how poetry again comes to the aid of science-understands how

"The whole round world is every way

Bound by gold chains about the feet of God."

And the weapon to be employed throughout the whole of this enquiry is not the intuitive, but the analytic and discursive intellect, whose province it is by patient and laborious investigation to demonstrate that Unity, in which the intuitive intellect, by reason of its affinity thereto, has always and everywhere found rest. 
The dialectic of Plato, like his conception of Good, is an ideal, and as such unattainable, perhaps,

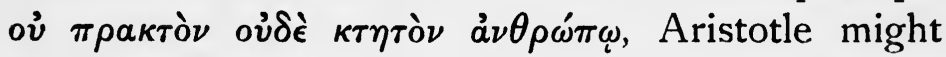
have said. Well, it is Plato's way to make us

"breathe in worlds

To which the heaven of heavens is but a veil."

And if we consider his dialectic simply as an ideal, it is, I venture to think, the kind of ideal for which, apart from idiosyncrasies of thought and language, philosophy is looking still, towards the realisation of which, if we believe in the unity of knowledge, every investigator does his part, in however humble a sphere, whether he studies man or nature, and whether he succeeds or fails, if only he is actuated by the love of truth. It is false to say that such an ideal is useless because it lies beyond our present powers. Some men are so constituted that they need the stimulus of the unattainable to make them reach the utmost limits of that to which they can attain. And in point of fact, an Ideal, as Plato well knew-I believe it to be the meaning of the one great paradox of the Ideal theory-an Ideal is from its very nature immanent as well as transcendent, always being realised in the progress we make

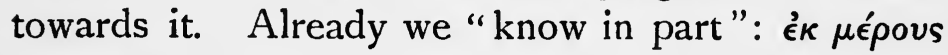
$\gamma\left(\nu \omega \sigma \kappa o \mu \epsilon \nu^{1}\right.$. The higher we climb the hill of knowledge in this life, the nearer we come to that transcendent Unity-call it by what name you will, the Absolute, or God, or Nature; for all our names 
are but a shadow of the Truth-wherein "are all the treasures of wisdom and knowledge hidden." But to Plato this life is not all : it is only a single stage upon our journey. The Platonic doctrine of immortality holds out the hope of a continuous advance throughout a series of lives until at last knowledge is made perfect. With perfect knowledge, too, comes perfect goodness or " assimilation to God"; for knowledge in Plato transforms the moral as well as the intellectual nature, and the Form of Good, which is the source of knowledge, is also the fountain of virtue. And in Plato as in Pindar, the ultimate proof of immortality - the proof that lies deeper than all his arguments and yet is heard throughout them all-is the kinship of the

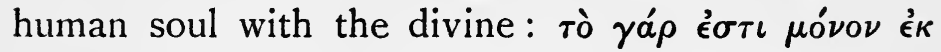
$\theta \epsilon \hat{\omega} \nu$.

In the speech delivered by $\mathrm{St}$ Paul before the council of the Areopagus, the doctrine which the apostle declares to be the common meeting-ground of Greek and Christian thought is just the doctrine which I have tried to explain and illustrate throughout this lecture. "In him we live and move and have our being; as certain even of your own poets have said, For we are also his offspring" : $\tau o \hat{v} \gamma \grave{a} \rho$

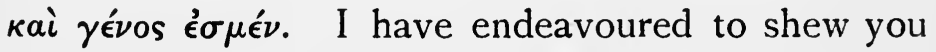
that St Paul might with equal truth have added "and as certain of your own philosophers have said": and I have tried to put before you what I believe the doctrine really means alike in Poetry and in Philosophy. The all-embracing and yet 
all-transcending unity, in which "we live and move and have our being" is just that ultimate reality which Religion, Philosophy and Poetry, each in its own language-remember, ő $\sigma \tau \iota s \pi o \tau^{\prime} \epsilon \hat{\boldsymbol{i}} \sigma \dot{v}$,

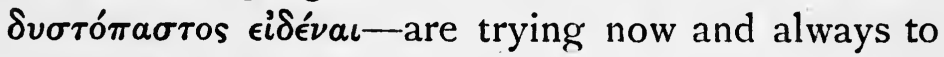
interpret to the human intellect or heart; and the doctrine of man's relationship to that great unity-

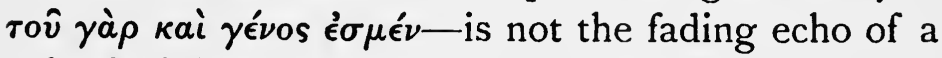
"dead philosophy": it is still, what Plato made it, the ever-living watchword of idealism.

In conclusion, I would ask you to link the present with the past by adding to the passages I have discussed the not less noble verses of our greatest living poet, himself a scholar in the highest or creative meaning of the word :

"Mother of man's time-travelling generations, Breath of his nostrils, heart-blood of his heart, God above all gods worshipped by all nations, Light above light, law beyond law thou art.

Thy face is as a sword smiting in sunder Shadows and chains and dreams and iron things: The sea is dumb before thy face, the thunder Silent, the skies are narrower than thy wings.

All old gray histories hiding thy clear features, $O$ secret spirit and sovereign, all men's tales, Creeds woven of men thy children and thy creatures They have woven for vestures of thee and for veils.

Thine hands, without election or exemption, Feed all men fainting from false peace or strife, $\mathrm{O}$ thou the resurrection and redemption, The godhead and the manhood and the life."

${ }^{1}$ Swinburne, Mater triumphalis. 


\section{THE DOCTRINE OF THE LOGOS IN HERACLITUS ${ }^{1}$}

There are few questions appertaining to the history of ancient philosophy which have been more widely and warmly debated than the meaning of the word dóyos in Heraclitus. By the ancients it was understood to mean reason-cosmic reasonuniversally diffused, present both in nature and in man, not of course one incorporeal entity, but identical with the ever-living, ever-thinking fire-

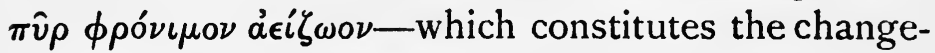
less because ever-changing reality of things: and

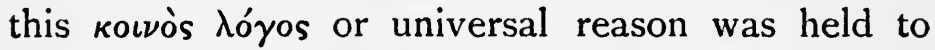
be synonymous with God. In other words, if the ancients are to be trusted, the Heraclitean concept of Logos does not really differ from the Stoic, except that on its material side, Logos is in Heraclitus fire, whereas, according to the strictest Stoic definition, it is aether. The ancient interpretation has

' [The references to Professor Burnet's Early Greek Philosophy are given according to the pages of the second edition except where otherwise stated; but his translations are quoted from the first edition, which alone was published in the lifetime of James Adam, and the variations in the second edition are noted.] 
been followed by many exponents of Heracliteanism in modern times, such as Bernays, Patin, Teichmüller, and, with certain reservations, Zeller; but others have taken a different view. Thus, for example, Heinze denies that the attribute of intelligence or thought belongs to the Heraclitean Logos: it is merely what he calls "objective reason," or law, the universal reason manifested in the development of the world, a principle destitute of anything analogous to consciousness or personality: and Professor Burnet goes so far as to maintain, if I understand him rightly, that the Logos-doctrine is entirely Stoic, the word Logos, in the relevant passages of Heraclitus, meaning only "argument" or "discourse." It is unnecessary to say more by way of shewing that this is one of those subjects on which doctors disagree; and I have selected it as the theme of my discourse, not so much with the hope of convincing others, as with the desire of being fortified in my own opinion-or the reverse -by the discussion which I trust my paper will provoke.

It will conduce to clearness if I say at the outset that, as at present advised, I believe the ancients were right in regarding the Heraclitean Logos as virtually identical with the Stoic, although the Stoic theory was of course far more fully developed and elaborated in detail.

The question "What does Logos mean in Heraclitus?" can be settled only by an examination of the fragments. Other evidence is ad- 
missible, but only by way of supplementing and confirming the results to which the fragments point; and I will therefore confine myself, in the first instance, to Heraclitus' own words.

The word dóyos occurs in six of the fragments. In at least one of these it is used in the ordinary

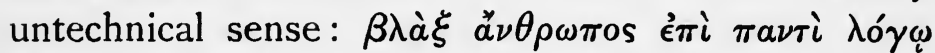

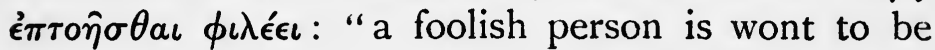
excited at every discourse ${ }^{1}$." In another muchdisputed fragment it is difficult to say whether the

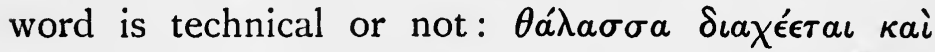

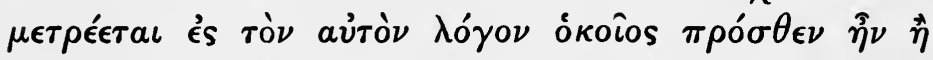
$\gamma \epsilon \nu \epsilon \in \sigma \theta \iota{ }^{\dagger} \gamma \hat{\eta} \dagger^{2}$ : " the sea is poured out and mea-

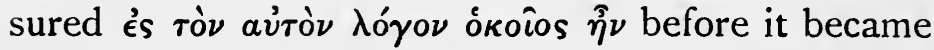
earth," or if (with Eusebius) we omit $\gamma \hat{\eta}$, "before it came into existence." Leaving this fragment on one side, let us consider the remaining four, in three of which at least Logos appears to have a special meaning. The first is the fragment placed first by $\mathrm{Mr}$ Bywater : in all probability it was the

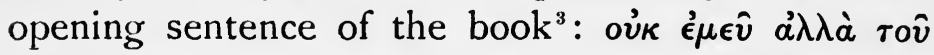

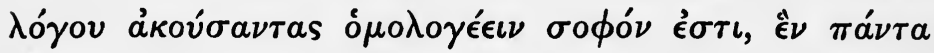
Gival: "having hearkened not to me, but to the Logos, it is wise to confess that all things are one." It is true that Hippolytus writes Só $\gamma \mu a \tau o s$

1 i 7 Bywater.

2 23. A summary of some of the different views entertained on this passage will be found in Patrick's Heraclitus, p. I 16 . For Burnet's view see Early' Greek Philosophy², p. I 48.

${ }^{3}$ There is nothing in Arist. Rhet. 1II. $1407^{\mathrm{b}} \mathrm{I} 4$ to contradict

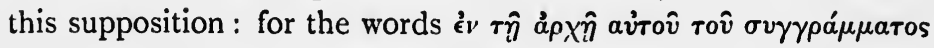
need not mean "in the first sentence." 


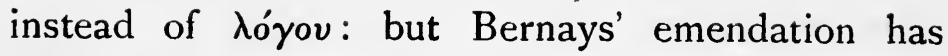
been accepted by all subsequent commentators, and the word $\delta$ ó $\mu a$ does not occur till at least a century after Heraclitus. On this fragment I will at present only add that Professor Burnet's translation, "It is wise to hearken not to me but my argument ${ }^{1}$," involves an antithesis which, though intelligible enough, is only partial, and scarcely adequate, I think, to the prophetic fervour of the sentence, particularly if these words began the book. "Hearken not unto me, but to the Logos": that is, it is not I, Heraclitus, who speak, nor anything that has to do with me, such as my argument, but the Logos that speaks through me: I am the mouthpiece of the Logos, and that is why I call on you to hear, not me, but it. Here, as elsewhere, Heraclitus speaks as if he believed himself to be inspired. "The Sibyl," you remember, "with frenzied mouth, uttering words unsmiling, unadorned, and unanointed, reaches with her voice throughout a thousand years by reason of the god ${ }^{2}$."

The second fragment seems to have followed

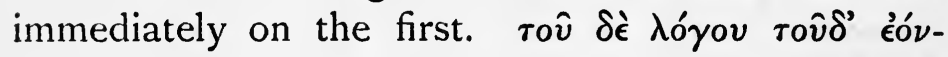

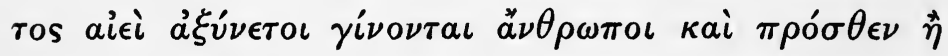

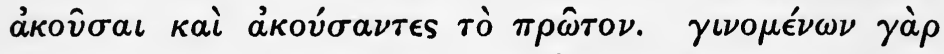

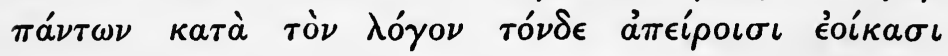

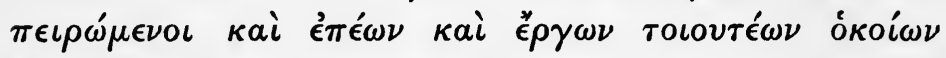

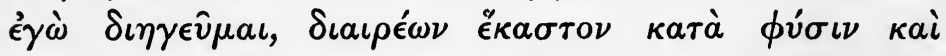

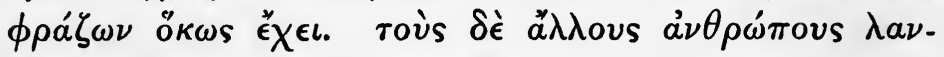

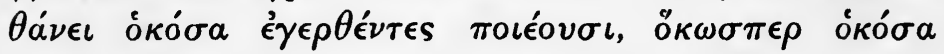

$$
1 \text { [In ed. } 2 \text { " to my Word."] } 2 \text { I } 2 .
$$




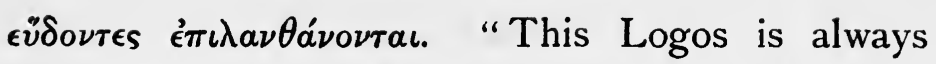
existent, but men fail to understand it both before they have heard it, and when they have heard it for the first time. For, although all things happen according to (or rather by way of) this Logos, men seem as if they had no acquaintance with it when they make acquaintance with such works and words as I expound, dividing each thing according to its nature, and explaining how it really is. The rest of mankind"- that is to say, presumably, all except Heraclitus, who professes to have read the riddle of the Universe- "are unconscious of what they do when they are awake, just as they forget what they do when asleep ${ }^{1 . "}$

The first sentence-

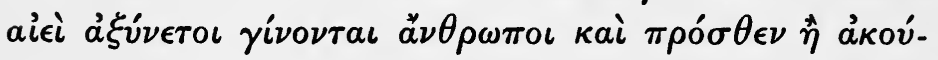

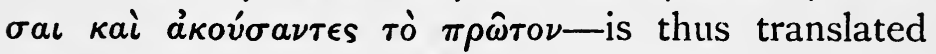
by Burnet. "Though this discourse ${ }^{2}$ is true evermore, yet men are as unable to understand it when they hear it for the first time as before they have heard it at all." No doubt éóvтos can mean "is true $^{3}$ ": but I submit that the expression "is true evermore," if "evermore" means anything, would suggest that it is possible for truth to be sometimes true and sometimes false. In point of fact, according to Professor Burnet's view, the adverb adds nothing to éóvтos: if a discourse is true, it is ipso facto always true. It is not like Heraclitus

$12 . \quad 2$ [In ed. 2 "Word."]

" [Burnet l. c. ${ }^{2}$ p. 146, says that in Ionic é $\omega^{\prime} v$ means "true" when coupled with words like $\lambda$ ó $\gamma$ os.]

A. E. 
to waste his words. The interpretation which I advocate gives its full and proper meaning to aici. The Being or Entity which Heraclitus calls גóyosthe Logos that speaks through him-is ever-existent, uncreated and imperishable: that is what the philosopher means; and we may compare not only what he says himself about the $\pi \hat{v} \rho$ a $\epsilon i \zeta \omega o \nu$, the "ever-living" Fire that "was and is and shall be

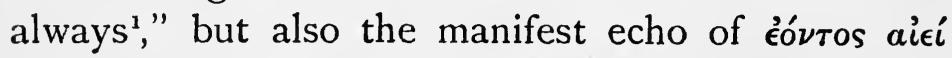

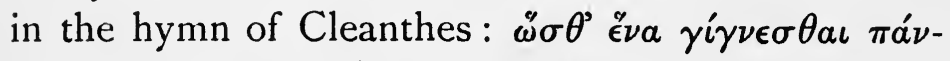

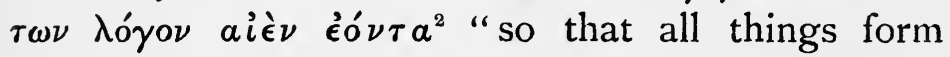
one Logos ever-existent." Consider next what is

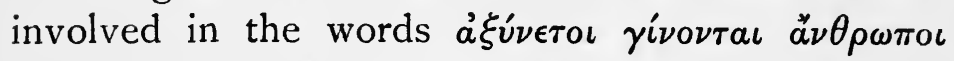

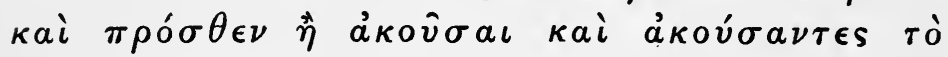
$\pi \rho \hat{\omega} \tau \circ \nu$. Professor Burnet translates: "men are as unable to understand it when they hear it for the first time as before they have heard it at all": but the two members of the clause кai $\pi \rho o ́ \sigma \theta \epsilon \nu \hat{\eta}$

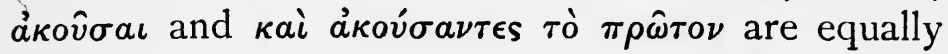
important in the Greek, and there is no indication that the first should be subordinated to the second: the natural translation is "men fail to understand the Logos both before they have heard it, and when they have heard it for the first time." It is clear that Heraclitus is blaming his fellow-men for not understanding the Logos before as well as after he expounds it: and the censure is virtually repeated in the next line: "men seem as if they had no

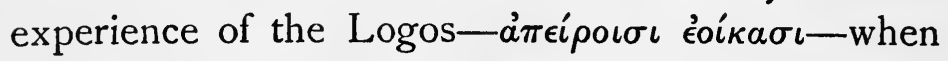
they make acquaintance with my account of it."

$$
120 . \quad 2 \text { line } 2 \text { I. }
$$


And such a censure is unjustified and meaningless unless Heraclitus believed it possible for his readers to apprehend the Logos otherwise than through the ear. The lesson, Heraclitus seems to say, is one that he who runs may read; it is present in our daily life and conversation; but men are altogether sunk in spiritual and intellectual slumber: "they know as little of what they are doing when awake as they remember what they do in sleep." As he complains elsewhere, they speak and act "as if they were asleep" ": they "do not understand the things with which they meet, nor when they are taught do they have knowledge of them, although they think they have." They are at variance with that with which they live in most continual intercourse ${ }^{3}$, being unable, in short, to interpret their own experience, for "eyes and ears are bad witnesses to those who have barbarian souls"." Now what is that "with which men live in most continual intercourse" ( $\stackrel{\tilde{\phi}}{\omega}$

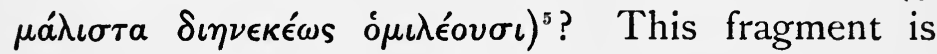
preserved by Marcus Aurelius, whose words are

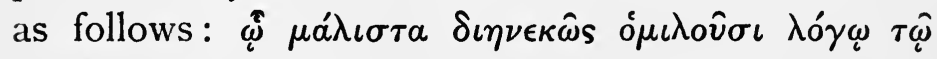

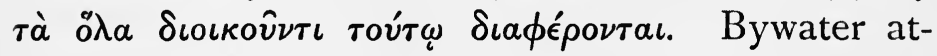
tributes to Marcus the whole expression $\lambda o ́ \gamma \omega \tau \hat{\varphi}$

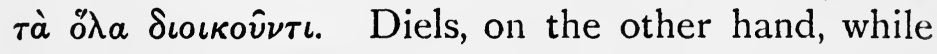
rightly holding Marcus responsible for $\tau \hat{\omega} \boldsymbol{\omega} \tau \grave{\alpha}$ ő $\lambda \alpha$

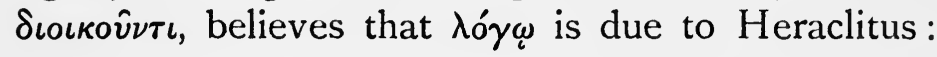

${ }^{1}$ Cf. 94,95 (sleepers turn aside into a world of their own, eis

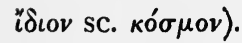

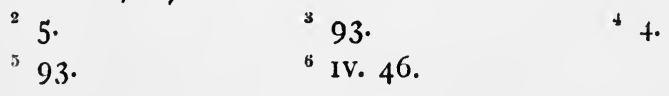




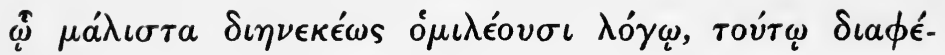

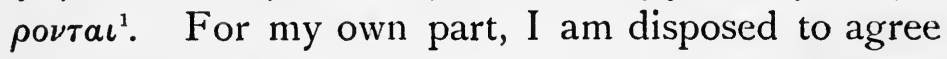
with Diels; but, in any case, that Heraclitus was thinking of the Logos may be in part inferred from what has been already said, and will appear more clearly in the sequel.

It would seem then that the Logos, whose prophet Heraclitus claims to be, is something of which we already have experience, even before we read its message in the book. It is, moreover, universal in its operation: "everything happens

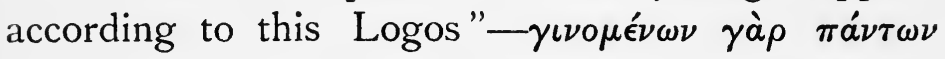

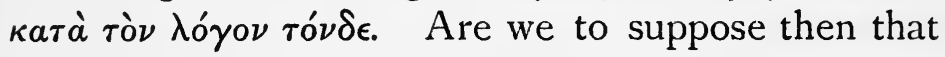
the Logos is only as it were the universal law prevailing throughout the realm of nature and humanity, what Heinze calls objective reason, devoid of active rationality or thought? Nothing has yet been said

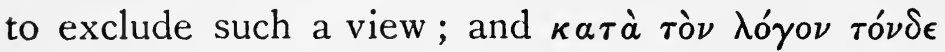
"in accordance with this Logos" might seem at first

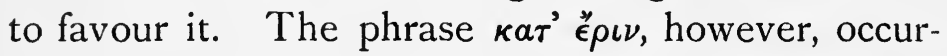
ring in other fragments of Heraclitus- $\pi \dot{\alpha} \nu \tau \alpha \kappa a \tau^{\prime}$ ' $\gamma^{\prime} \nu \epsilon \sigma \theta a \iota^{2}$ - shews that $\kappa a \tau a$, in Heraclitus, may very well mean " by way of," " through," without implying the negation of activity in the noun it governs: for Strife, in Heraclitus, is admittedly something active. And when we consider one of the other fragments in which the Logos is named, we shall find reason for believing that the Heraclitean Logos is possessed of intelligence. The fragment I refer to runs thus:

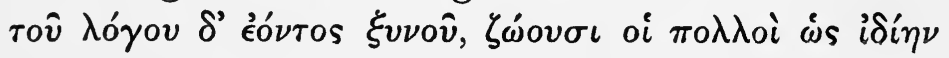

$$
{ }^{1} 72 \text { Diels. }{ }^{2} 46 \text { : cf. } 62 .
$$




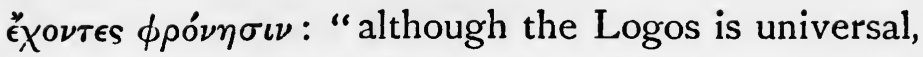
most men live as if they had a private intelligence of their own ${ }^{1}$." If we remember Heraclitus' inveterate tendency to antithesis and balance we cannot escape

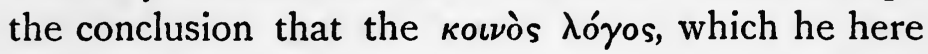

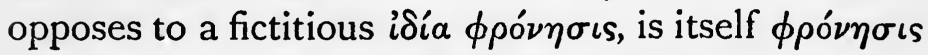

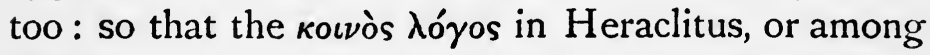
the Stoics, is rational, and thinks. Professor Burnet,

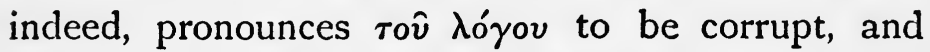
substitutes $\tau o \hat{v} \phi \rho o \nu \epsilon^{\prime} \iota \nu$ on the strength of another fragment to which I will presently refer: alleging

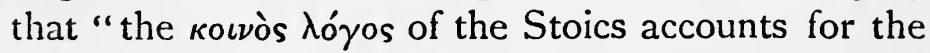
change" ": but no one, I think, has followed him in this petitio principii.

With one exception, which will shortly be mentioned, these are all the fragments in which $\lambda$ óyos has an apparently technical sense. The provisional conclusion we have reached is that the Logos, according to Heraclitus, is eternal and universal-immanent alike in nature and in man-and that it is endowed with the attribute of thought. The one remaining fragment is that in which Heraclitus pays a compliment to Bias of Priene. "In Priene lived Bias, son

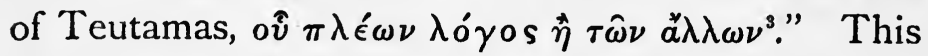
does not mean, "who is of more account than the

92.

2 l.c. ${ }^{1}$ p. r 40. [In ed. 2, p. I53 Burnet begins the fragment

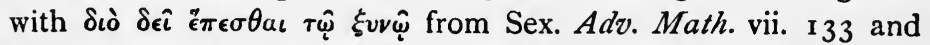

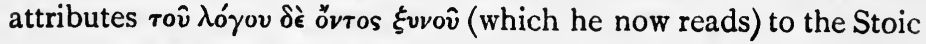
interpreter whom Sextus is following.]

8 I I 2. 
rest," as Burnet takes it ${ }^{1}$ : still less is Dr Patrick right: "whose word was worth more than that of others": nor yet should we translate (with Diels fr. 59) "von dem mehr die Rede ist als von den anderen." Heraclitus means simply that Bias had more of the Logos-the universal and eternal Logos-in him than the other teachers ${ }^{3}$ of the Greeks, Pythagoras,

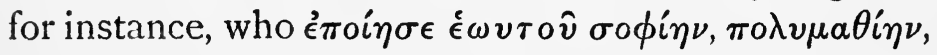
какотє $\chi^{\nu i \eta \nu}$ " made a wisdom of his oron, a heap of learning and a heap of mischief." It is natural enough that one who looked upon himself as the vehicle of the Logos- "listen not to me, but to the Logos "- should attribute an exceptional measure of the same inspiration to the man who forestalled him in the characteristically Heraclitean sentiment: oi $\pi о \lambda \lambda о$ какоі

Let us now consider some of the other fragments which appear to throw light upon the nature of the Logos, without, however, mentioning it by name. "There is but one wisdom," says Heraclitus, "to know the knowledge by which all things are steered

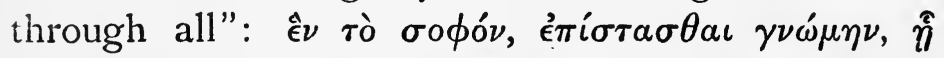

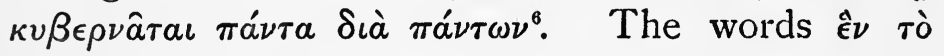
$\sigma \circ \phi o ́ \nu$, as I understand them, are directed against the multiplicity of private and particular "wisdoms," put forward by 'Heraclitus' predecessors, such as Hesiod, Pythagoras, Xenophanes and Hecataeus,

1 p. 154.

2 l.c. p. 110.

${ }^{8}$ Patin, Heraklit's Einheitslehre, p. 56, comes near to this suggestion, without exactly making it.

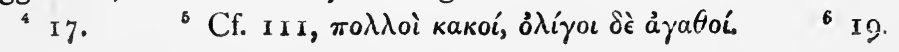


whom he vituperates in fragment 16 ; but it is with the second part of the sentence that we are chiefly concerned. What is the $\gamma \nu \omega^{\prime} \mu \eta$ "by which all things are steered through all"? Remembering that "all things come to pass by way of the Logos "- $-\gamma \iota \nu \circ \mu$ '́ $\nu \omega \nu$

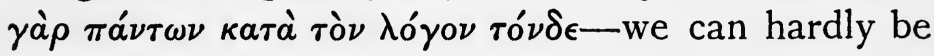
wrong in identifying with the Logos the $\gamma \nu \omega \mu \eta$ by which all things are steered: from which, of course,

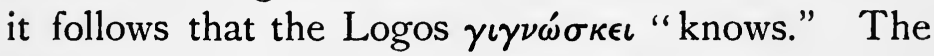
omniscience of the Logos would also seem to be implied in the impressive sentence "Who can escape

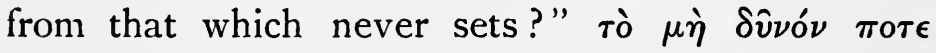
$\pi \hat{\omega} s \stackrel{a}{\nu} \tau \tau \iota s \lambda \alpha^{\prime} \theta \iota^{1}$; for it can hardly be doubted that Heraclitus is here thinking of the never-dying

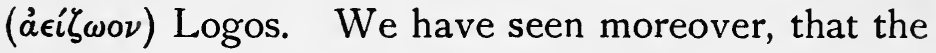
Logos in Heraclitus is common or universal- $\xi v \nu o$ s.

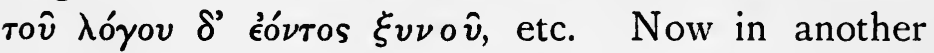
well-known fragment thought is expressly said to

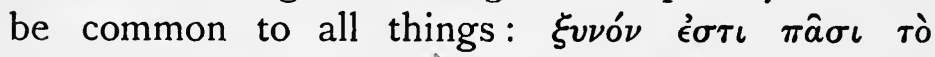
$\phi \rho o \nu \epsilon \epsilon \nu^{2}$. In strict logic, of course, this would not establish the identity of the two conceptions: but Heraclitus is not a logician, and if we remember that $\xi v \nu o ́ v$ is one of his favourite catch-words we may

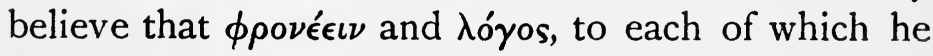
assigns the property of $\xi \nu \nu o ́ \tau \eta s$, were in point of fact inseparably connected in his mind.

I will now invite you to consider one or two of the fragments in which the philosopher speaks of the world-forming fire. If fire in Heraclitus is only as it were the material embodiment of Logos, we

$$
\begin{aligned}
& 127 . \\
& \quad 91 .
\end{aligned}
$$


shall expect to find-supposing we are right so farthat he attributes rationality also to this element. The fragments which may fairly be held to justify us in identifying the Logos with fire are two in number. In fragment 20 we read of the "everliving fire," that "was and is and shall be always," identical with the world-order or cosmos. Presumably this is the same as the $\lambda$ ó $y$ os which always is :

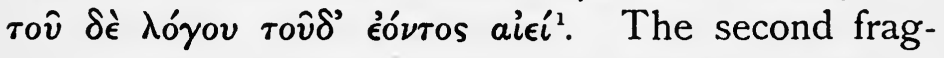
ment speaks of the thunderbolt as steering all things:

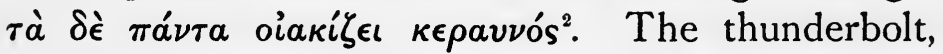
of course, is only an oracular name for fire; and we have an exact parallel to this fragment in the sentence

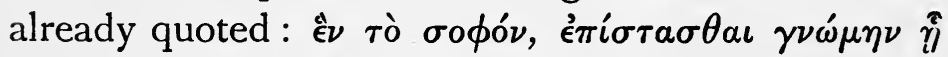

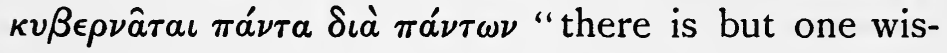
dom, to know the knowledge by which all things are steered through all." Now we have seen that this $\gamma \nu \omega^{\prime} \mu \eta$ is the Logos, so that the fire which steers all things is itself the Logos. And the metaphor in

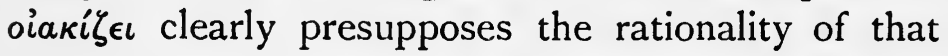
which steers the world. The connexion of intelligence with the warm dry element of fire appears moreover in the psychological fragments of Heraclitus. "The dry parched soul is wisest and best"-

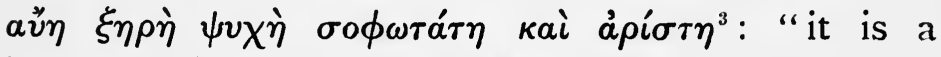
joy to souls to become wet ${ }^{4}$-with the implication of course that it is better to be dry: "when a man is drunk, he is led by a beardless boy, stumbling, not knowing the way he goes, because his soul is wet ${ }^{5}$."

$\begin{array}{lll}12 . & 28 . & 374,75 . \\ 72 . & 53 . & \end{array}$


On these grounds, then, I believe that the fragments of Heraclitus are in themselves sufficient to

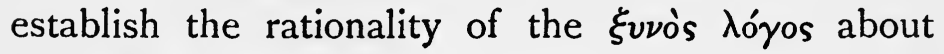
which he speaks. By way of confirmation, I will remind you of the well-known passage in which Sextus Empiricus, or rather Aenesidemus-for it is Aenesidemus he is following here-seems to be paraphrasing the account of the Logos contained in Heraclitus' own book. "It is the opinion of the philosopher," says Sextus, "that what encompasses us is rational" (入оуєкó $\nu)^{\prime}$ and possessed of intelli-

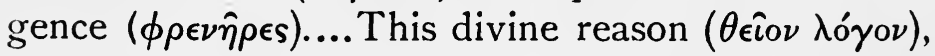
according to Heraclitus, we draw in by means of respiration, and so we become actively intelligent ( fulness, but our intelligence returns when we awake. For during sleep, when the sensory avenues are closed, the mind within us is separated from its connexion with the encompassing element, except that the union by means of respiration is preserved as a sort of root; and the mind when it has thus been separated loses the power of memory which it previously had. But when we are awake, the mind peeps out again through the avenues of sense, as if through windows, and, coming into contact with the

${ }^{1}$ Sextus thinks of air, but the element of air does not appear to be recognised by Heraclitus. If Heraclitus used rò $\pi \epsilon \rho$ léxov at all, he can only have meant by it fire, for the atmosphere which we breathe, according to Heraclitus, is nothing but fire in one of its manifold transmutations. This passage helps to bring vividly before our minds the general character of Heraclitus' conception, with its curious intermixture of spirituality and materialism. 
encompassing element, puts on the power of reason

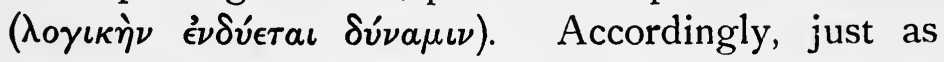
embers, when they are placed near the fire, change and become red-hot, so in like manner the portion of the encompassing element which is quartered in our body becomes all but irrational when it is separated, while on the other hand it is rendered homogeneous with the whole by being connected therewith through the majority of avenues ${ }^{1}$." It is true, no doubt, that the phraseology of this extract, and some of the ideas which it contains, are postHeraclitean: in particular, as Professor Burnet has pointed out, "the distinction between mind and body is far too sharply drawn" for Heraclitus. But in the words of the same authority, "we can hardly doubt that the striking simile of the embers which glow when they are brought near the fire is genuine ${ }^{2}$ "; and I may add that the pervading idea of the whole passage, which is that our intellectual life is nourished and sustained by physical communion with the element that surrounds us on every side, is only the materialised form of the doctrine which is the foundation of Heraclitean ethics $\delta \epsilon \hat{\imath} \stackrel{\epsilon}{\pi} \pi \sigma \theta a \iota \tau \hat{\varphi} \xi \boldsymbol{\xi} \nu \hat{\omega}$ " follow the universal," i.e. the $\operatorname{Logos}^{3}$. And if we admit that the simile is Heraclitean, we must equally admit that it is meaningless and absurd, unless the surrounding

${ }^{1}$ Adv. Math. vir. $127 \mathrm{ff}$.

2 l.c. p. $\mathrm{I} 70 \mathrm{f}$.

3 Fr. 2 Diels. I agree with Patin, Gomperz and others in attributing these words to Heraclitus. Bywater takes a different view : see $f r .92$. 
element is rational. The fire we breathe must be permanently maintained at a level of actual thought which enables it to kindle our smouldering reason

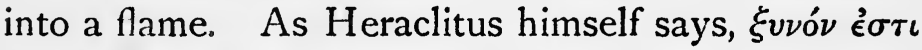

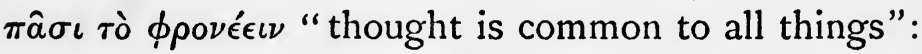

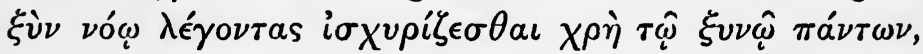

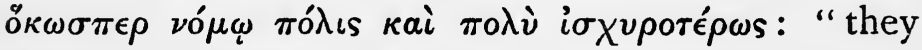
who speak with the reason should strongly cleave to that which is common to all things, as a city cleaves to law, and much more strongly": $\tau \rho \in$ é

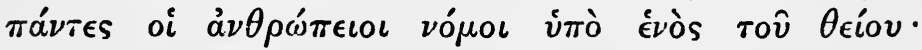

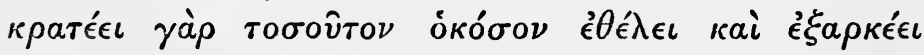
$\pi \hat{\alpha} \sigma \iota \kappa a i \quad \pi \epsilon \rho \iota \iota^{\prime} \epsilon \tau \alpha \iota$ "for all human laws are nurtured by the one divine law: for it prevails as much as it will and suffices for all and has something over." This divine law is manifestly just the $\theta$ cios dóyos in which, according to the testimony of the ancients, Heraclitus believed.

It would accordingly seem that the Logos of Heraclitus is a unity, omnipresent, rational, and divine, the guiding and controlling cause of everything that comes to pass whether by the agency of man or of nature. "From the visible light," says Clement, "we may perchance hide, but it is impossible to hide from the intellectual, or in the words of Heraclitus: "how shall a man hide from that which

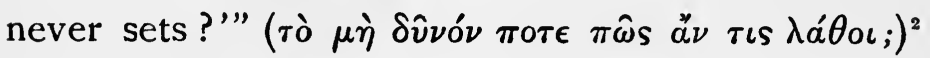
Against the view which I am now defending it is sometimes urged that "the word dóyos did not mean

191.

2 27. Clem. Paedag. 516 c, Migne. 
Reason at all in early days." In my opinion this is hardly a correct statement of the point at issue : the question is not whether $\lambda$ ó $\gamma$ os in Heraclitus is exactly synonymous with Reason: it is whether his Logos possesses the attribute of Reason, and this can be determined only by such a comparative study of the fragments as I have attempted above. It is a mere petitio principii to assert that Logos in early Greek has nothing to do with reason if what Heraclitus says of Logos cannot be otherwise correctly understood. Heraclitus may quite well have been the first to use the word with such an implication. But in point of fact, as Teichmüller has shown', the word Logos and its congeners- $\delta i a \lambda \epsilon^{\prime} \gamma \in \sigma \theta a \iota$, for instance,

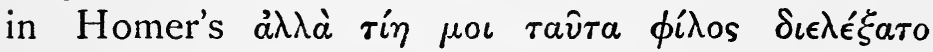
$\theta v \mu$ ós;-even before the time of Heraclitus, frequently imply reflection or thought; and soon after Heraclitus we meet with $\lambda$ óyos in Parmenides with the meaning of reason or ratiocination, as opposed

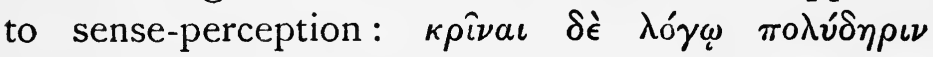

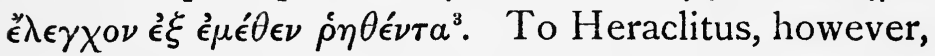

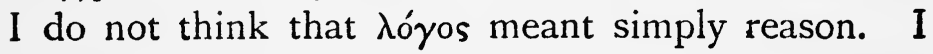
think he conceives of it rather as the rational principle, power, or being which speaks to man both from without and from within - the universal Word, which for those who have ears to hear is audible

1 Burnet, l.c.' p. 133 n. ${ }^{13}$. [In ed. 2, p. 146 n. $^{8}$ this statement is modified as follows: "The Stoic interpretation given by Marc. Aur. iv. $4^{6}$ (R. $P .3^{2}$ b) must be rejected altogether. The word 入óos was never used like that till post-Aristotelian times."]

${ }^{2}$ Neue Studien, I. $6_{7}$ ff.

${ }^{3}$ Parm. 1. $3^{6}$ f. Diels. 
both in Nature and in their own hearts. Such an interpretation seems to suit all the fragments in which he speaks of the Logos, more especially the first, "having hearkened not unto me, but to the Logos, it is wise to confess that all things are one." In his somewhat hurried review of the different

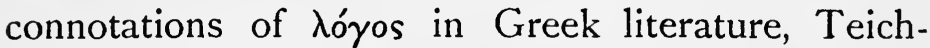
müller says nothing about Epicharmus; and as the fragments which bear the name of this philosopherpoet furnish some confirmation of the view which I have ventured to put before you, it may be worth while to examine what they have to say upon the subject.

The principal fragments ascribed to Epicharmus, you may remember, belong to one or other of three classes. First come the dramatic remains, the authenticity of which is now acknowledged, I believe, by all. Secondly, we have about fifteen fragments of the Carmen Physicum. Whether these are genuine or not is a question still debated. Rohde and Diels attribute them to Epicharmus, while von Wilamowitz-Möllendorff and Kaibel consider them spurious, the latter however maintaining on sufficient grounds that they date from the fifth century before Christ, and were known to Euripides ${ }^{1}$. The third set of fragments are supposed by Kaibel to be taken from the Politeia of Chrysogonus, the flute-player, who wrote in the end of the fifth century B.c. Aristoxenus, as we learn from Athenaeus, assigned some of the $\psi \epsilon v \delta \epsilon \pi \iota \chi \alpha ́ \rho \mu \epsilon \iota a$ to this source.

${ }^{1}$ See Kaibel, Comicorum Graecorum fragmenta, I. p. I $33 \mathrm{ff}$. 
Now in the first and third of these three collections we have several traces of Heracliteanism. Let us take the admittedly genuine fragments first. In fragment I 70 (Kaibel) the poet takes the Heraclitean doctrine of universal flux, and applies it for the first time in Greek literature to the question of the permanence of human personality. If you increase or diminish a number, it is no longer the same as before. Similarly with human beings:

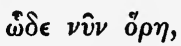

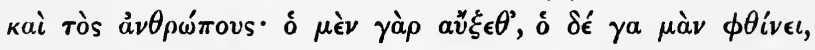

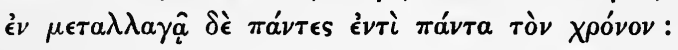

from which the inference is drawn that you and I are different persons to-day from what we were yesterday, and from what we shall be again to-morrow. This interesting fragment has been admirably discussed by Bernays ${ }^{1}$, who shews that it originated the problem

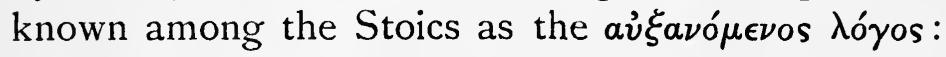
but it does not bear directly on our subject, and I mention it here only to illustrate the way in which Epicharmus gives a particular application to one of the fundamental principles of Heraclitus. The same tendency to work out Heracliteanism in detail reveals itself in fragment 172, which deals with the universality of thought and is little more than an elaboration

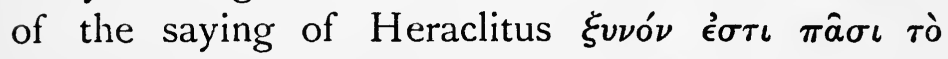
$\phi \rho o \nu \epsilon \epsilon \iota \nu$. The first two lines are as follows :

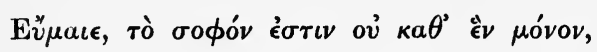

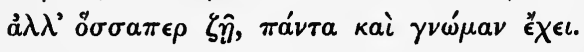

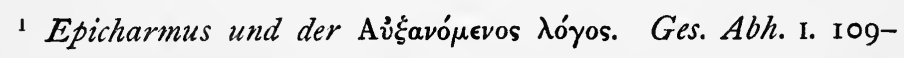
I 7 . 
Everything that has life, has also $\gamma \nu \omega \dot{\mu a \alpha}$. In Heraclitus however it would seem that the Logos is not confined to living objects, any more than in Stoicism. The rest of the fragment of pseudoEpicharmus seems to mean that although eggs have no $\gamma \nu \omega \mu \alpha$ when they are laid, yet the hen by sitting on them makes them live, and then they have $\gamma \nu \omega \dot{\mu} \mu$. The two last verses are :

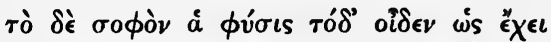

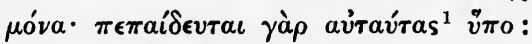

i.e. (I think) Nature alone knows the secret of this wisdom (how this wisdom is), for she is her own teacher: not (as Cobet) et huius norunt principem sapientiae naturam solam, quae magistra ipsis fuit. We may compare the saying of Heraclitus $\phi \dot{v} \sigma \iota s$ $\kappa \rho \dot{\pi} \pi \tau \sigma \theta a \iota \phi \iota \lambda \epsilon \hat{i}^{2}$. But to return. The fragments of the Carmen Physicum contain nothing that is suggestive of Heraclitus, except an allusion to the circulation of the elements ${ }^{3}$. In the third collection, however, we have what is, I think, the most explicit statement of the Logos-doctrine to be found between the time of Heraclitus and that of the Stoics.

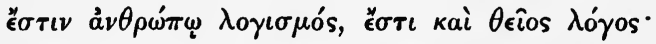

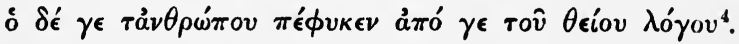

${ }^{1}$ So Porson for av̉ tav́ras.

2 Since writing the above, I observe that Diels interprets the fragment in the same way (Frag. d. Vorsokratiker ${ }^{2}$, I. p. 91). With the general sentiment cf. Empedocles, fr. I го. Iо Diels, $\pi \alpha \dot{v} v \alpha$

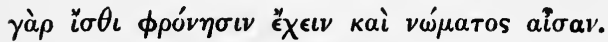

${ }^{3}$ See fr. 239, 240 Kaibel.

${ }^{4}$ Diels, l.c. p. 98 (fr. 57. 2, 3). 
The derivation of the human soul from the gods had already been affirmed by Pindar and others; in Euripides and Plato we meet with the doctrine that the human $\nu o \hat{v} s$ is in its origin and nature divine; but so far as I am aware, this is the only passage in Greek literature, until we come to the Stoics, which appears to be definitely and immediately inspired by the Heraclitean doctrine of Logos. It seems to me clear that the author of these lines written, as I have said, in the end of the fifth century before Christ, not only had Heraclitus in his mind, but interpreted the Logos as I have done.

$\mathrm{Up}$ to this point we have considered the Logos merely as immanent-immanent in nature and in man. But the Stoics regarded it in yet another aspect : it was also the concors discordia rerum - the harmony in which all mutually antagonistic tendencies or forces, both in the moral and in the physical world, are reconciled. I need only remind you of the lines of Cleanthes:

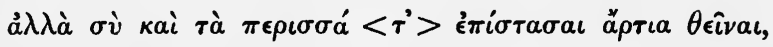

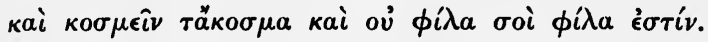

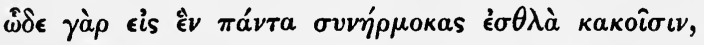

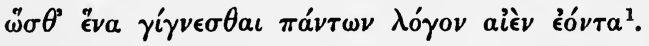

"Nay, but thou knowest to make crooked straight: Chaos to thee is order; in thine eyes The unloved is lovely, who didst harmonise Things evil with things good, that there should be One Word through all things everlastingly"."

1 I 8-2 I.

${ }^{2}$ For other illustrations of this characteristically Stoic doctrine see the passages in von Arnim Stoiconum fragmenta veterum II. $\$ \S$ I 68 ff. 
There can be no doubt that the general conception of a supreme and ultimate unity or harmony of opposites goes back to Heraclitus. As Professor Burnet has remarked, "opposites," in Heraclitus, "are but the two faces of the fire which is the thought that rules the world ${ }^{1}$." "Opposition," Heraclitus says,

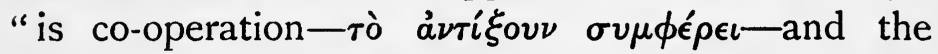
fairest harmony results from differences" ${ }^{2}$ ": "were there no higher and lower notes in music, there could be no harmony at all"." "As with the bow and the lyre, so with the world; it is the tension of opposing forces that makes the structure one":

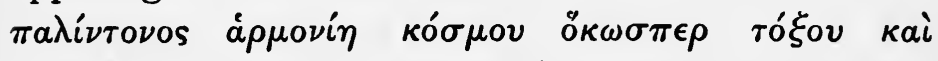
$\lambda \dot{v} \rho s^{4}$. The sum of the whole matter is contained in the fragment: "Join together that which is whole and that which is not whole, that which agrees and that which disagrees, the concordant and the discordant : from all comes one and from one comes all" ":

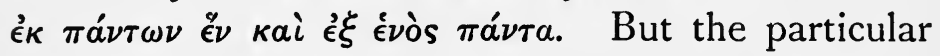
question which concerns the student of the Logos doctrine is whether Heraclitus, like the Stoics, considered this ultimate unity to be the Logos. I think there is every reason to suppose he did. For in the first place he complains, as we have seen, that the multitude are ignorant of the Logos: " they are at variance with that with which they live in most continual intercourse": "they seem as if they had no experience of the Logos both before they hear it and when they have heard it for the first time":

$\begin{array}{lll}{ }^{1} \text { l.c. }{ }^{2} \text { p. } 144 \text { f. } & 246 . & 33 . \\ +56 . & & 59 .\end{array}$

A. E. 
"although the Logos is universal, they live as if they had a private intelligence of their own." And in like manner he complains that the multitude do not understand that "hidden harmony" which is "better than the visible" ": "they do not understand," he says, "how that which is discordant is concordant with itself"." It is a fair inference that this hidden harmony is the Logos. In the second place, it is the Logos of which Heraclitus at the very outset of his book proclaims himself to be the prophet. "Listen not to me but to the Logos." And the doctrine in which his preaching actually culminates - the last word of Heraclitus, so to speak-is not the universal flux or warfare, but the underlying harmony of all the opposing forces that make up the universal life. This was well understood in antiquity, and is now generally recognised by modern writers on Heraclitus, among others by Professor Burnet. In a passage of Philo, to which Patin ${ }^{3}$ was the first to assign its due importance in the history of Heraclitean criticism, we read as follows : "That which is made up of both the opposites is one, and when this one is dissected, the opposites are brought to light. Is not this what the Greeks say their great and celebrated Heraclitus put in the forefront of his philosophy as its sum and substance, and boasted of as a new discovery?"

We are consequently bound to suppose that in the Logos whose prophet Heraclitus declared him-

\footnotetext{
147. 245.

3 l.c. p. 6o. Philo, Quis rer. div. haer. 43.
} 
self to be, all opposites are reconciled. The Logos reveals itself through him, and what it reveals, that is, the Logos itself, is unity. "Having listened not to me, but to the Logos, it is wise to confess that all things are one." Thirdly, we may arrive, I think, at the same conclusion by yet another way. It is tolerably clear that dóyos in Heraclitus is to be identified with $\theta \epsilon$ ós. Various indications point in this direction. The epithet "divine" is applied by

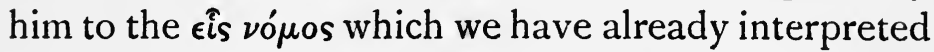
as the Logos, the $\nu$ ó $\mu$ os which "prevails as much as it will and suffices for all and has something over"." We are told by Clement of Alexandria that "Heraclitus the Ephesian believed fire to be God"," and the identification is generally admitted, although M. Bovet sees nothing in it beyond a metaphor ${ }^{3}$. Metaphor or no metaphor, it does not matter much : for in Heraclitus metaphor is truth: no one can read his fragments without realising this fact. And if fire in Heraclitus is God, the Logos must be God; for we have seen that the dó yos on its material side is fire. There is also at least one fragment of the philosopher himself which appears to deify the Logos. "There is but one Wisdom: it wills not and yet wills to be called by the name of Zeust." The "one Wisdom" is manifestly the Logos, or "thought by which all things are steered through all"

$9 \mathrm{r}$. ${ }^{2}$ Coh. ad Gent. p. I65 A, Migne.

"Le Dieu de Plalon, p. $102 . \quad 465$. 
the true objective reality which men ignorantly worship under that name ${ }^{1}$ : on the other hand, it rejects the appellation for the reasons which prompted Heraclitus to declare that Homer and Archilochus should be scourged and cast out of the arena. The Logos has none of the anthropomorphic or other degrading attributes and passions belonging to the Homeric Zeus. And if Logos in Heraclitus is equivalent to $\theta \epsilon o$ s, the Logos must certainly be that ultimate reality in which all opposites are reconciled : for Heraclitus expressly says that "God is day and night, winter and summer, war and peace, satiety

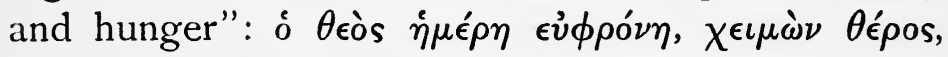

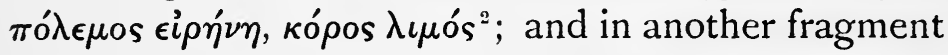
we have the idea that to God all things are beautiful and good and right, but men think some things wrong and others right ${ }^{3}$. In short, when Cudworth speaks of God as "reconciling all the variety and contrariety of things in the universe into one most lovely and admirable harmony ${ }^{4}$," he exactly expresses one of the principal ideas which I think Heraclitus connected with his doctrine of the Logos.

If the view which I have put before you is correct, we must suppose that Heraclitus was first and foremost a prophet and a theologian rather than a man of science; and it is as a theologian that he is regarded by many scholars, notably by Tannery in

\footnotetext{
${ }^{2}$ Cf. Zeller, Phil. der G. , I. 2, p. 670, n. 3 .

${ }^{2} 36 . \quad{ }^{3} 6 \mathrm{I}$.

+ Intellectual System of the Universe, p. 207.
} 
his Science Hellène. The hierophantic and oracular nature of Heraclitus' style points to the same conclusion; he himself says that "the lord, whose oracle is at Delphi, neither utters plainly nor yet conceals his meaning, but speaks by signs " (ả $\lambda \lambda \grave{a} \sigma \eta \mu \alpha i v \epsilon \iota)$, and he seems to have deliberately modelled his style upon Apollo's. I may add also that the fragment

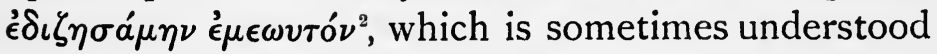

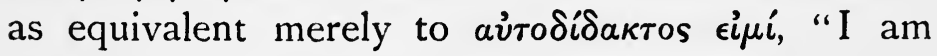
self-taught," "I enquired of myself," ought, I think, when interpreted by the light of the fragments already discussed, to be understood in the deeper and more mystical sense "I investigated myself," i.e. it was by self-study, by looking within and not without that I discovered the secret of the

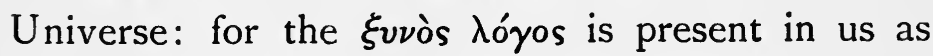
well as without.

"The beauty thou dost worship dwells in thee:

Within thy soul divine it harboureth:

This also bids my spirit soar, and saith

Words that unsphere for me Heaven's harmony ${ }^{3}$."

This is of course a favourite idea in every age with thinkers of the school to which Heraclitus seems to have belonged. "In te ipsum redi: in interiore homine habitat veritas," as Augustine says.

I have endeavoured to shew that the Heraclitean Logos is at once the Divine Reason immanent both in Nature and in man, and also the unity in which all

\footnotetext{
1 II. 280.

3 Campanella, Sonnets, tr. Symonds.
} 
opposites are reconciled. The first of these two conceptions-I mean the doctrine of the divine immanence-appears again and again in Greek philosophy between the time of Heraclitus and the rise of Stoicism; but the second-the notion of a world-unity or harmony of differences-is comparatively rare, I think, in Greek literature until Cleanthes. Some have thought that this is the leading idea in the drama of Sophocles. "Undeserved suffering," says Professor Butcher, "while it is exhibited in Sophocles under various lights, always appears as part of the permitted evil which is a condition of a just and harmoniously ordered universe ${ }^{1 . "} \quad$ Nestle has endeavoured to show, not, I think, successfully, that Euripides held the same belief, and borrowed it from Heraclitus. According to Euripides, he says, "the whole world, material as well as moral, depends on the reciprocal play of opposites, which however have no absolute value. And thus the entire Cosmos reveals itself as a work of unalterable law, which Heraclitus, and after him Euripides, call Dike, so that in the view of both this Dike is not simply a moral but a cosmic force." There are traces of the belief in Plato, particularly in

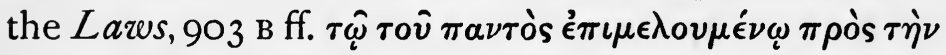

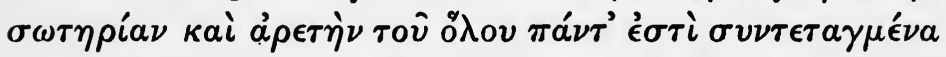

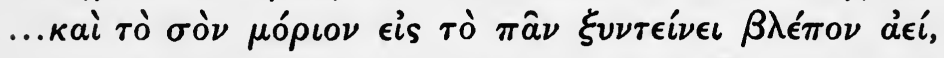

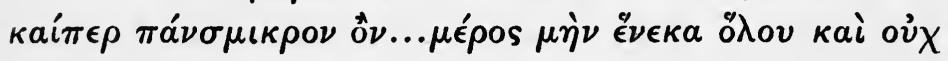

\footnotetext{
1 Some Aspects of the Gr. Genius, p. 127.

2 Euripides, p. $15 \mathrm{I}$.
} 
Heraclitus founder of Logos doctrine 103

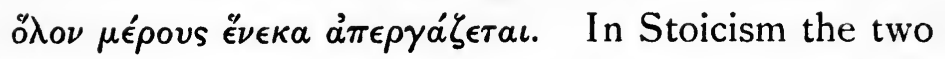
essential characteristics of the Logos are that it is omnipresent and that it reconciles the seeming contrariety of things into a perfect harmony; and since each of these characteristics belongs to the Heraclitean $\lambda$ ó os, we are justified in holding that Heraclitus, and not the Stoics, was the founder of the doctrine, which has played so great a part in later religious and philosophical thought. 


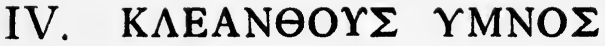

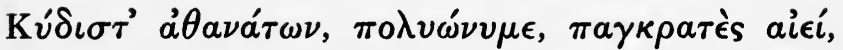

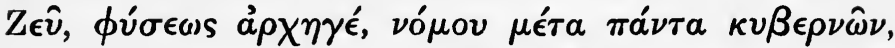

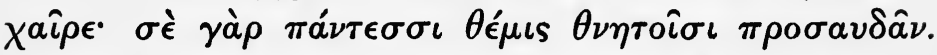

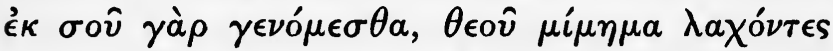

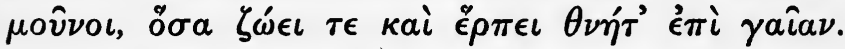

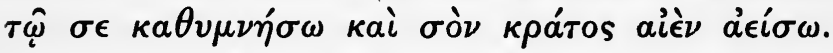

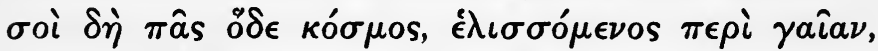

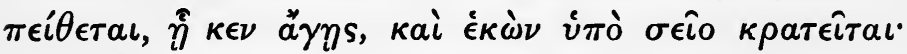

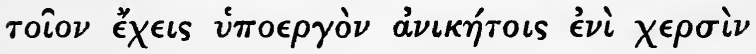

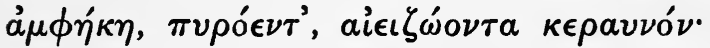

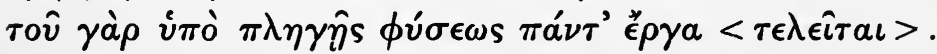

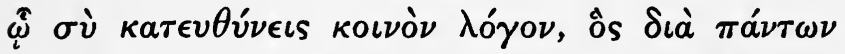

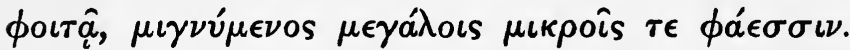

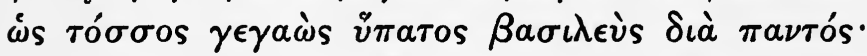

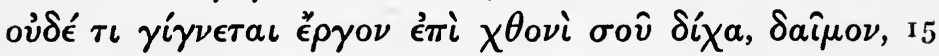

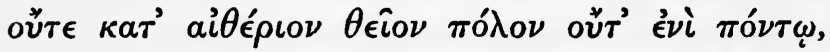

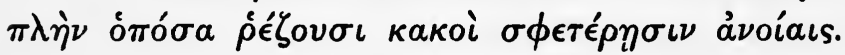

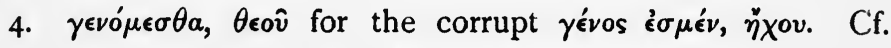

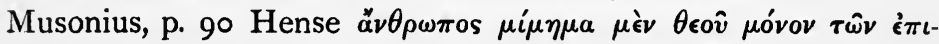

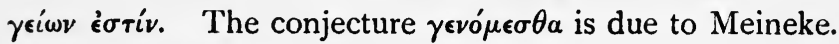

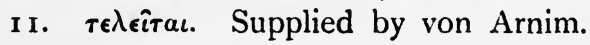

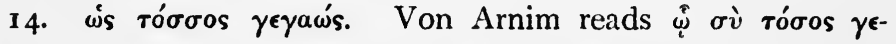

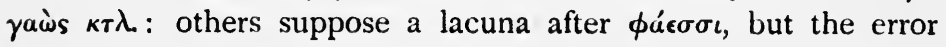
seems incurable. 


\section{THE HYMN OF CLEANTHES}

O God most glorious, called by many a name, Nature's great King, through endless years the same ;

Omnipotence, who by thy just decree Controllest all, hail, Zeus, for unto thee Behoves thy creatures in all lands to call.

We are thy children, we alone, of all

On earth's broad ways that wander to and fro,

Bearing thine image wheresoe'er we go.

Wherefore with songs of praise thy power I will forth shew.

Lo! yonder Heaven, that round the earth is wheeled, IO

Follows thy guidance, still to thee doth yield

Glad homage; thine unconquerable hand

Such flaming minister, the levin-brand,

Wieldeth, a sword two-edged, whose deathless might

Pulsates through all that Nature brings to light; 15

Vehicle of the universal Word, that flows

Through all, and in the light celestial glows

Of stars both great and small. $\mathrm{O}$ King of Kings Through ceaseless ages, God, whose purpose brings To birth, whate'er on land or in the sea

Is wrought, or in high heaven's immensity;

Save what the sinner works infatuate. 


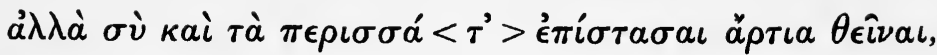

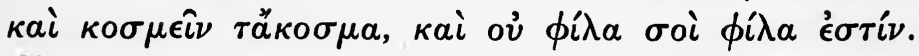

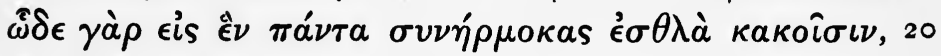

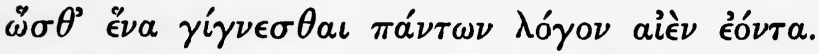

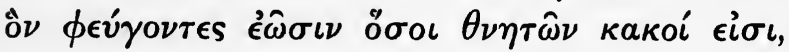

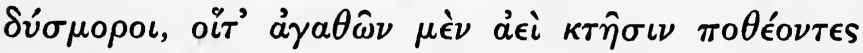

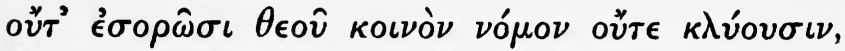

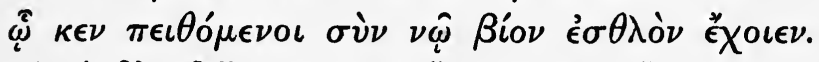

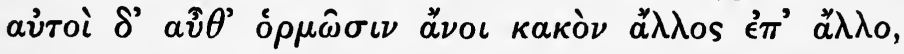

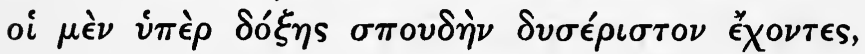

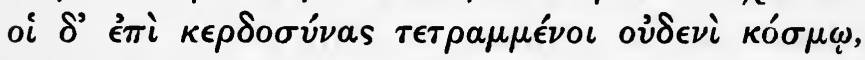

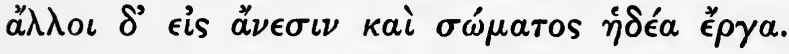

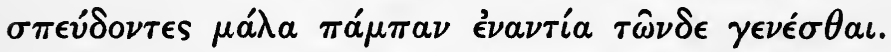

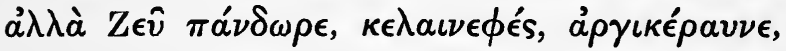

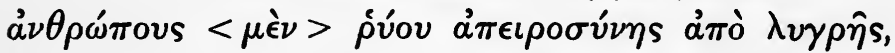

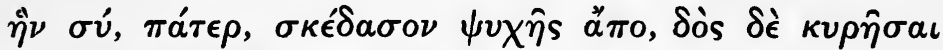

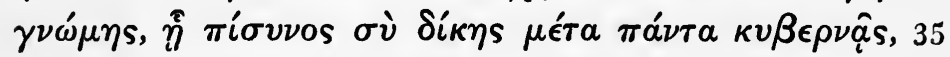

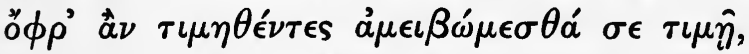

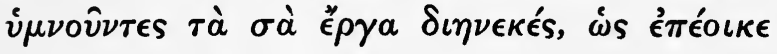

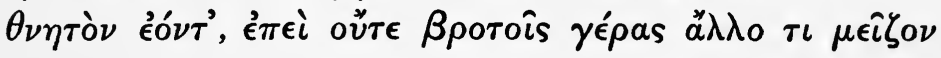

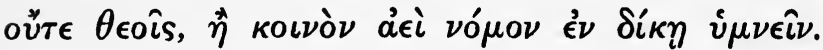

30. Von Arnim conjectures that the missing words may

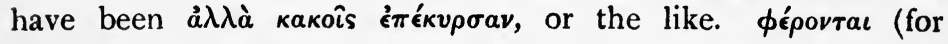
ф'́povtes of the MS) is due to Meineke. 
Nay, but thou knowest to make crooked straight:

Chaos to thee is order: in thine eyes

The unloved is lovely, who didst harmonize

Things evil with things good, that there should be

One Word through all things everlastingly.

One Word-whose voice alas! the wicked spurn;

Insatiate for the good their spirits yearn:

Yet seeing see not, neither hearing hear

God's universal law, which those revere,

By reason guided, happiness who win.

The rest, unreasoning, diverse shapes of $\sin$

Self-prompted follow: for an idle name

Vainly they wrestle in the lists of fame:

Others inordinately riches woo,

Or dissolute, the joys of flesh pursue.

Now here, now there they wander, fruitless still,

For ever seeking good and finding ill.

Zeus the all-bountiful, whom darkness shrouds, $4 \circ$

Whose lightning lightens in the thunder-clouds;

Thy children save from error's deadly sway:

Turn thou the darkness from their souls away:

Vouchsafe that unto knowledge they attain;

For thou by knowledge art made strong to reign 45

O'er all, and all things rulest righteously.

So by thee honoured, we will honour thee,

Praising thy works continually with songs,

As mortals should; nor higher meed belongs

E'en to the gods, than justly to adore

The universal law for evermore. 


\section{THE HYMN OF CLEANTHES}

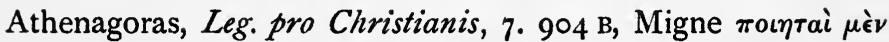

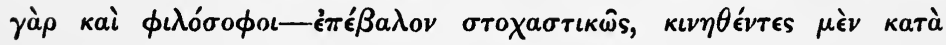

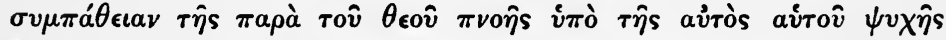

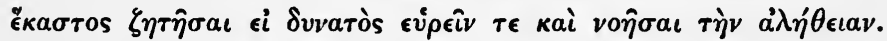

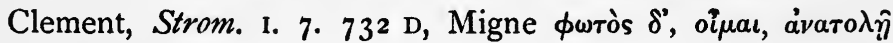
$\pi a ́ v \tau a \phi \omega \tau i \zeta \in \tau a \iota$.

My object in these lectures is to expound and illustrate the religious significance of Stoicism, in connexion more especially with the hymn of Cleanthes. But before we can profitably enter on the subject before us, it is necessary to say a word or two about the development of religious thought in Greece before Stoicism began. Leaving out of account everything of merely secondary importance, we can distinguish in Greek literature-and it is with literature alone that we are now concernedtwo main lines of religious development, the one represented by the poets from Homer to Sophocles, and the other by the philosophers from Thales down to the Stoics. The poets for the most part accepted the leading features of the old Homeric theodicy, with its polytheism and anthropomorphism; but a tolerably continuous progress can be traced in the growing emphasis which was laid upon the higher 
and more idealistic elements in Homer's theology, to the suppression or comparative neglect of the grosser anthropomorphic features, and more particularly in the gradual spiritualisation of Zeus. The father of Gods and men in Aeschylus and Sophocles is a Being infinitely more capable of inspiring religious devotion and faith than the Homeric Zeus, who combines in a single personality the two opposing principles of Naturalism and Idealism, and is always violating the law of righteousness, to which he nevertheless requires, on pain of severest penalties, his human subjects to conform. It would be impossible, for instance, to find a true Homeric parallel to the beautiful hymn to Zeus that occurs in the Suppliant Maidens of Aeschylus-I quote it according to Mr Morshead's admirable rendering-

"Though the deep will of Zeus be hard to track

Yet doth it flame and glance

A beacon in the dark, 'mid clouds of chance

That wrap mankind.

Yea, though the counsel fall, undone it shall not lie, Whate'er be shaped and fixed within Zeus' ruling mind.

Dark as a solemn grove, with sombre leafage shaded,

His paths of purpose wind,

A marvel to man's eye.

Smitten by him from towering hopes degraded

Mortals lie low and still:

Tireless and effortless works forth its will

The arm divine!

God from his holy seat, in calm of unarmed power, Brings forth the deed at the appointed hour ${ }^{1}$ !" 
And there is little or nothing in Homer to correspond to the sentiment of entire dependence on the justice of the Supreme God to which the Chorus in Sophocles' Electra give expression when they thus console the maiden :

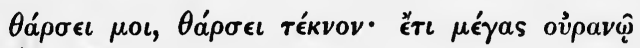

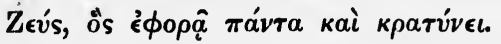

"Courage, my child, courage: great Zeus still reigns in heaven, who oversees and governs all'".

At the same time, even in Sophocles, with whom the purely poetical development of Greek religious thought reaches its highest point, the inherent dualism of the Homeric theology has by no means disappeared altogether. Like most of his countrymen, Sophocles is still content to speak of the omnipotent Gods as the authors of evil not less than of good: he does not ascribe to them moral purity, any more than Homer: we find passages in his plays which seem to endorse such traditional doctrines as the envy of the Gods and the infatuation or Ate by which they drive men into sin; and above all, there is hardly a suggestion in Sophocles of the view that did more, perhaps, than anything else to purify the theology of Greece - the view that the divine nature must be such as to furnish a moral standard or ideal to humanity, so that the supreme rule of conduct for man becomes ó $\mu$ oi $\omega \sigma \iota s \tau \hat{\varphi} \theta \epsilon \hat{\varphi}$ " assimilation to God." One such trace is to be found in the Oedipus at Colonus 
I 267 ff., where Polynices makes this touching appeal to his father :

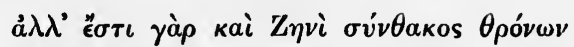

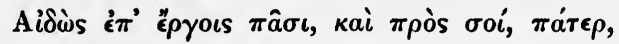
$\pi \alpha \rho a \sigma \tau a \theta \dot{\eta} \tau \omega$.

"But forasmuch as Zeus himself hath mercy for the partner of his throne, shall she not also find a place by thee, my father?"

This is the motive which makes nature-religions into ethical religions.

If we turn on the other hand from the poets to the philosophers, we find ourselves at once in a totally different atmosphere. At a very early period, Greek philosophy raised the standard of revolt against the authority of Homer in matters appertaining to religion and theology. The attempt of the early Ionic philosophers to discover a single creative cause of the Universe, itself uncreated and imperishable, was, however unconsciously-and I am not sure that they were all of them wholly unconscious of the goal to which they were travelling -was a step, I say, in the direction of monotheism; and when Xenophanes of Colophon in the sixth century before Christ explicitly affirmed the existence of "one God, supreme in heaven and earth, neither in body nor in mind resembling man" it became clear that philosophy would not be satisfied with merely purifying the old Homeric faith: nothing short of a revolution would suffice. The Homeric religion must be discarded altogether, and replaced 
by something better fitted to satisfy the highest moral and religious aspirations of man, and at the same time to furnish, if possible, an explanation of nature in which the human intellect could rest.

It has been pointed out by Plato that this feud between philosophy and poetry - a feud which arose mainly from the odium theologicum - was one of the salient features in the history of Greek literature down to the early part of the fourth century before Christ. If we look at it from a somewhat wider point of view, we may say, I think, that it is one of the most significant and pregnant phenomena in the history not only of literature, but of religion, and not of Greek religion merely, but of the religious development of the human race. On the one hand, as a German writer has said, we have poetry, "immortalising in imperishable creations the traditional faith, and on the other hand, we find philosophy, just on account of that faith, condemning those creations," and at the same time, I think we may add, furnishing materials for a new and deeper conception of the Godhead and his relation both to man and nature. Positively, as well as negatively, therefore, Greek philosophy-the philosophies of Xenophanes, of Heraclitus, above all of Plato and the Stoics--to a certain extent points the way to Christianity and Christian thought, whether we express the connexion by the favourite Clementine formula of a divinelyappointed education of mankind, in the scheme of which philosophy is as it were the propaedeutic 


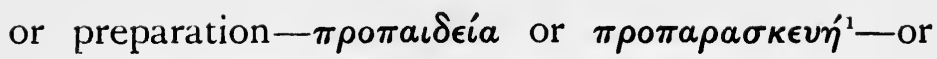
whether we say that there is a real continuity, historical perhaps as well as philosophical, between the theoretical ideals of Greek thinkers and their more or less imperfect-for as yet they are only imperfectly realised-I say their more or less imperfect realisation in Christianity ${ }^{2}$.

It is from this point of view, then, as expressive of a kind of movement in the direction of Christian and post-Christian ways of thought and feelingphilosophical thought and religious feeling-that I would ask you to consider the hymn of Cleanthes. Of the life and character of its author we know enough to make us anxious to know more. He was born probably in 331 B.C., in the town of Assos in Asia Minor, eight years before the death of Alexander the Great. Nothing is known to us of the circumstances under which he came to Athens and began the study of philosophy under Zeno; but his zeal for knowledge is attested by the well-authenti-

${ }^{1}$ Cf. Clement, Strom. 1. 2. 709 в, Migne, Philosophy a' $\lambda \eta \theta \epsilon i a s$

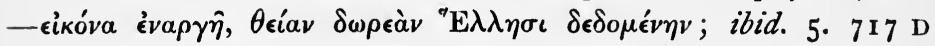

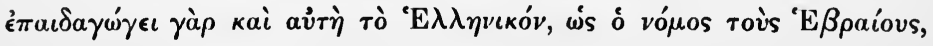

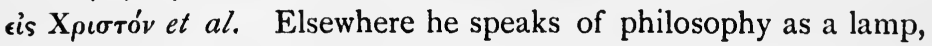
Christ as the sun, and so forth. Cf. also vi. 392 C 'Iovdaious

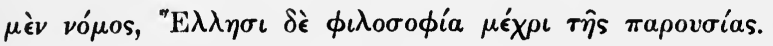

${ }^{2}$ There may be a historical connexion, on the one hand through Stoicism, which flourished at Tarsus, and on the other through Jewish Hellenism. Much remains to be done in this field of enquiry. At present there are mainly dogmatic assertions, on the one side and on the other, with regard to the existence or non-existence of such a connexion.

A. E. 
cated story that he used to earn "his living by drawing water at night, in order to devote the daytime to study." In course of tirne he succeeded Zeno in the presidency of the Stoic school or college; for by this time Athens had become-what she continued to be until Justinian closed the philosophical schools in the sixth century A.D.-a kind of University town; and the different schools, Academic, Peripatetic, Stoic and Epicurean, were in reality so many independent colleges, each with a tradition, organisation and discipline of its own ${ }^{2}$. He continued head of the school for thirty-two years, from 264 till his death in 232 B.c. Of his work as a teacher a single anecdote is preserved illustrating the slow and painstaking character of his disputations. It is said that the more versatile and perhaps more superficial Chrysippus, on whom the presidency of the college afterwards devolved ${ }^{3}$, became tired of listening to the long and tedious arguments of his master, and impatiently exclaimed on one occasion: "Give me your conclusions, and I will find the proofs"." But, in spite of this anecdote, Cleanthes was assuredly none of your "dry-as-dust," mechanical pedants. In

1 Pearson, Fragments of Zeno and Cleanthes, p. 35.

2 See von Wilamowitz-Möllendorff, Phil. Untersuch. Iv, Antigonos von Karystos, $263 \mathrm{ff}$. The Academy and Lyceum were originally half-religious foundations, organised like religious associations

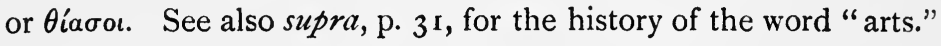

3 Diog. Laert. vir. 183 , reports that it was commonly said of

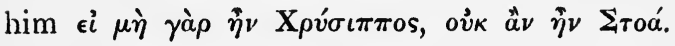

4 Perhaps this is a little characteristic of moral philosophers at all times; proofs are excogitated to establish theories. 
none of the earlier Stoics is there so rich a vein of religious as well as philosophical inspiration-a kind of suppressed enthusiasm for whatever is adorable and great in nature and in man, breaking out from time to time in strongly emotional, sometimes halforacular utterances such as recall to us the fragments of the great teacher to whom, as it seems to me, Cleanthes owed more than to all other writers put together-I mean Heraclitus of Ephesus. As to the influence of Heraclitus upon Cleanthes, there is no room for doubt; we shall find, indeed, that the surviving fragments of the Ephesian sage are incomparably the best commentary on the hymn which it is the object of these lectures to interpret.

The further question, whether Cleanthes' conception of God and Nature may not have owed something to Semitic theology, is not so easy to determine. The conquests and statesmanship of Alexander had prepared the way for that fusion of Eastern and Western thought out of which so much that is of the highest and most permanent value in modern religious theory was afterwards developed; and Sir Alexander Grant pointed out long ago that "not a single Stoic of note was a native of Greece proper": all of them came from the East, many of them "from Semitic towns and colonies"." He even goes so far as to say that the "essence of Stoicism consists in the introduction of the Semitic temperament and a Semitic spirit into Greek philosophy"." In his essay on St Paul and

1 The Ethics of Aristotle, vol. i. p. 308.

Ibid. 3 Ibid. p. 309. 
Seneca, Bishop Lightfoot has further elaborated this view of Stoicism, holding that "to Eastern affinities Stoicism was without doubt largely indebted for the features which distinguished it from other schools of Greek philosophy"," in particular "the intense moral earnestness which was its most honourable characteristic ${ }^{2}$," the distinctively prophetic rather than dialectical character of Stoic teaching $^{3}$, its " recognition of the claims of the individual soul, the sense of personal responsibility, the habit of judicial introspection, in short the subjective view of ethics" -all of which features, he asserts, now for the first time "presented themselves at the doors of Western civilisation and demanded admission"."

A still more striking resemblance between Stoicism and Judaism is to be found in the firm belief, which the greatest of the Stoic teachers had in the essential unity of the divine nature, and here it might be possible to quote by way of illustration the remarkable parallel afforded by the philosophy of Spinoza, between which and Stoicism the affinity is very great. Sir Frederick Pollock has pointed out that the pantheism of Spinoza ${ }^{6}$, himself by birth a Jew, was to a large extent a philosophical development of Hebrew monotheism; and in like manner it might be conjectured that Stoic pantheism arose in somewhat the same way. But in point of fact, as will be partially

1 Dissertations on the Apostolic Age, pp. 252 ff.
2 Ibid.
4 Ibid. p. 253.
3 Ibid. p. 255.
5 Ibid.
- Spinoza, his Life and Philosophy, chap. III. p. 82. 
evident, I hope, from the illustrations I shall put before you, nearly all of these so-called Semitic ideas are already to be found somewhere or other in Greek literature, especially in the philosophy of Plato; and the question rather is, whether and to what extent the Semitic element in Stoicism, if it was really there, helped to bring these ideas into greater prominence and give them new life and vigour. That the Eastern origin of so many of the Stoics operated in this direction, there cannot, I conceive, be any doubt; but it is an entire mistake to separate the history of Stoicism from that of Greek philosophy in general, and so far as Cleanthes in particular is concerned, we have no positive evidence that he was in any way influenced by Semitic thought. The key to nearly all his greatest ideas, as I have already said, is to be found in Heraclitus.

With these preliminary remarks, let us now turn to a consideration of the hymn itself. So far as I know, it has not yet been discussed and illustrated with the care which it deserves. Mr Pearson's commentary, in his Fragments of Zeno and Cleanthes, is excellent so far as it goes, but it hardly professes to do much more than explain the text. The Hymn of Cleanthes demands the fullest possible treatment alike on its poetical, its religious and its philosophical side: it is in fact, like the Timaeus of Plato, which one of the ancients described as a "hymn of the Universe," a blend of poetry, religion, and philosophy, summing up not only most of the best and most inspiring ideas of Stoicism, without any of the 
Stoic aridity and trivialities, but also much of the noblest Greek thought on God and man and nature from Heraclitus down to Aristotle, and foreshadowing, in no obscure fashion, what we sometimes erroneously suppose to be the religious and philosophical discoveries of Christendom ${ }^{1}$.

A glance at the Hymn will show you that it falls naturally into four divisions.

A. We have first the prelude (lines $\mathbf{I}-6$ ), the burden of which is "let us praise Zeus; for we are of his family, and made in his image." Here it is apparently the religious motive which is predominant.

B. The second division, extending from line 7 to line $2 \mathrm{I}$, speaks of the operation of the divine power throughout the world: all things in external Nature obey the law of God. These lines contain more of the philosophy of Stoicism than any other part of the hymn. The religion of humanity is merged in a yet wider ideal-the religion of the universe ${ }^{2}$.

C. In the third section, comprising from line 23 to line 35 , the poet describes how human creatures

1 Clement speaks of Cleanthes as having written $\dot{\epsilon} \pi \iota \pi v o$ ía $\theta \epsilon \circ \hat{v}$, Coh. ad Gentes, 180 в, Migne.

${ }^{2}$ See Höffding, Philos. of Religion, p. 290. This passage illustrates what Höfding calls the sympathetic type of the religious disposition. Cf. St Paul, Rom. viii. 22 f. "The whole creation groaneth and travaileth in pain together until now. And not only they, but ourselves also, which have the first-fruits of the Spirit, even we ourselves groan within ourselves": cf. also the conception of the dóros in St John and in St Paul. 
fall away through ignorance, and prays for their enlightenment and restoration. The ethical and religious motive comes to the front again in this section.

D. Finally, the note which was struck in the prelude is resumed at the conclusion of the hymn (36-39). So shall we praise the universal law, and thus fulfil the highest privilege accorded to men and gods.

I will discuss each of these four sections in order.

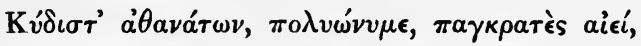

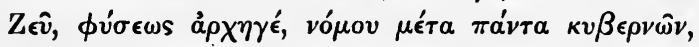

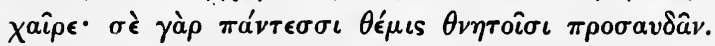

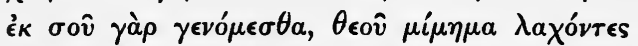

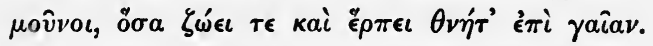

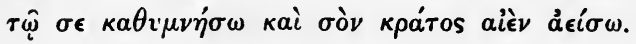

"O God most glorious, called by many a name, Nature's great King, through endless years the same;

Omnipotence, who by thy just decree Controllest all, hail, Zeus, for unto thee Behoves thy creatures in all lands to call. We are thy children, we alone, of all On earth's broad ways that wander to and fro, Bearing thine image wheresoe'er we go.

Wherefore with songs of praise thy power I will forth shew."

Let us begin by considering the epithet $\pi \circ \lambda \nu \omega ́ \nu v \mu \epsilon$ "called by many a name." Cleanthes, like the Stoics in general, was a believer, of course, in one God, whom he identified, as will afterwards be seen, with the soul of the world, or rather with Reason immanent in the universe; and $\pi \circ \lambda v \omega \nu \nu \mu \epsilon$ signifies that all the different gods of polytheism are only so many 
different names, or perhaps embodiments of the universal Spirit, according to the different spheres in which that Spirit works, or-which amounts to the same thing-the different aspects in which he is regarded ${ }^{1}$. We meet with the same idea in an impressive fragment of Heraclitus": "God is day and night, summer and winter, war and peace, satiety and hunger; but he is changed, just as, when incense is mingled with incense, it is named according to the flavour of each." It is highly probable, I think, that this fragment actually suggested to the Stoics the method by which they contrived to reconcile their philosophic pantheism with the religious polytheism of the Greeks ; but the important point for us to notice is that the epithet $\pi \circ \lambda \nu \omega \dot{\nu} v \mu \epsilon$ implies far more than a mere "accommodation" on the part of a philosopher to the popular religion. It ought not to be limited in its application to the gods of the

${ }^{1}$ Cf. Max Müller's Hibbert Lectures, p. 3 I I. One poet in the Veda, for instance, says "They call him Indra, Mitra, Varuna, Agni; that which is and is one, the wise name in diverse manners." Cf. also the Monotheistic tendency among the Babylonians. In one inscription, dating perhaps from 2000 в.C. or so, we have a list of identifications of the different gods with special aspects of the supreme god Merodach.

Bêl is Merodach of lordship and domination,
Nebo " " $\quad$ trading, etc.,
Sin the illumination of the night,

and so forth. See Pinches, The Religion of Babylonia and Assyria, p. 118. This tendency to a reconciliation with polytheism is of course characteristic of pantheism in every age.

${ }^{2}$ Fr. 36 (following Bywater's text). 
Greek pantheon: rather it implies that all mankind, in every age and country, worship one and the same God, by whatever name they call him. Numina sicut nomina, according to the Latin saying. In

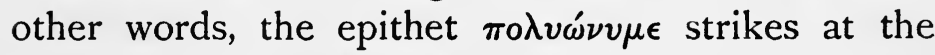
very outset of the hymn a note of universalism; the God whom Cleanthes invokes is not the god of the Greek alone, or of the barbarian : he is the God of the whole human race. The old exclusiveness of fifth century Hellenism has disappeared; and in its place we have the wider and more comprehensive ideal of a religion coextensive with humanity itself. It is true that Cleanthes calls his God by the distinctively Hellenic name of Zeus; but, owing in large measure to the teaching of Greek drama, the concept of Zeus had already been universalised, more especially by Sophocles ${ }^{1}$ in his doctrine of a divine law whereof Zeus and Zeus alone is guardian, a law engraved by him in the hearts and consciences of all men, without distinction of race or creed, and of prior obligation to the ordinances made by man; and the Zeus of Cleanthes is free from every vestige of exclusiveness or particularism.

The same conception, that God is god of all mankind, and not merely of one particular race or people, is again emphasized in the third line: $\sigma \grave{\epsilon}$

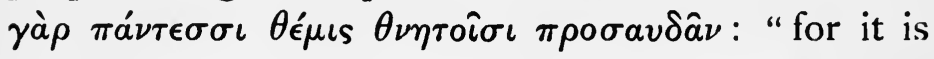

${ }^{1}$ Cf. Socrates' advice to worship God vó $\mu \omega$ пó $\lambda \epsilon \omega s$, Xen. Mem. i. 3. I, and Plato, Rep. 427 c, where Apollo, as the $\pi a ́ r p \iota s$ $\dot{\boldsymbol{k}} \xi \eta \gamma \eta \tau \dot{\eta}$ 's of Zeus, is said to expound at Delphi the will of Zeus, the universal father, $\pi \hat{a} \sigma \iota v \dot{a} \nu \theta \rho \omega$ inoıs_-" to all mankind." 
meet all mortal men should call upon thy name." Observe now what is the foundation on which Cleanthes builds his dream of a universal, worldwide, religion. '̇́ $\sigma o \hat{v} \gamma \grave{\alpha} \rho \gamma \epsilon \nu$ ó $\mu \epsilon \sigma \theta \alpha$ - "for we"that is all human creatures-"are thine offspring, made in the likeness of God, alone of all things mortal that live and move upon the earth." In Stoicism, indeed, not man alone, but universal nature is the creation - in a certain sense the offspring of God; but man is the only creature who can properly be said to be made in the image of God, and it is on these two grounds combined-man's kinship with God, and man's likeness to God-that the poet declares it to be the privilege of every human creature to call upon his name. We have here-in

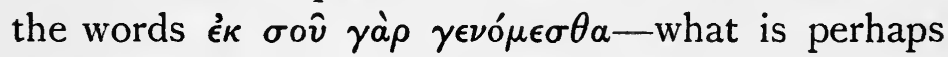
the most famous expression in Greek literature of the profoundly religious as well as philosophical doctrine of man's celestial origin and nature, a doctrine that appears in nearly all the best Greek thought about religion from Pindar down to Epictetus, and is in an especial sense the property of Stoicism. There is, you will remember, the authority of St Paul for looking on this great doctrine as the common meeting-ground of Greek and Christian thought ${ }^{1}$. It is true that in the speech which he

1 See Findlay in Hastings' Dictionary of the Bible, s.v. Paul, where it is well pointed out that St Paul looks on man as God's kindred, and salvation as the recovery of sonship. Cf., with

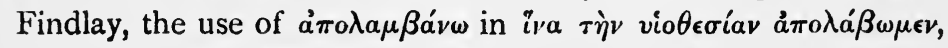

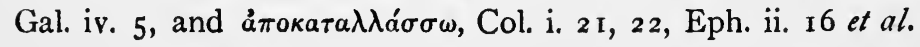


delivered before the council of the Areopagus at Athens we find hardly a single idea, except the bodily resurrection of Jesus Christ, which cannot be abundantly illustrated from Greek sources; but the sentiment on which the great prophet of Christianity as the divinely-appointed universal religion rightly lays most stress, is just this Stoic doctrine of the kinship between man and God. "God-hath made of one blood all nations of men for to dwell on all the face of the earth, and hath determined the times before appointed, and the bounds of their habitation: that they should seek the Lord, if haply they might feel after him, and find him, though he be not far from any one of us : for in him we live, and move, and have our being "- a Stoic would rather have said, perhaps, "God lives in us." "As certain also of your own poets have said, For we are also his

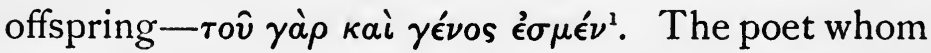
St Paul has in his mind is not indeed Cleanthes, but Aratus; and in all probability, as Norden in his Antike Kunstprosa ${ }^{2}$ has pointed out, the quotation is taken not directly from Aratus, but from Aristobulus, a hellenizing Jew who flourished about I 50 B.C., and was the first to maintain what afterwards became a favourite patristic theory, that Plato derived all his wisdom from Moses, being in fact only M $\omega v \sigma \hat{\eta} s$

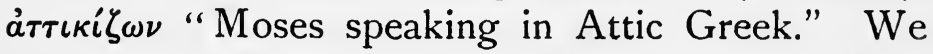
know from Eusebius ${ }^{3}$ that Aristobulus cited in support of his audacious theory that part of Aratus
1 Acts xvii. 26-28.
${ }^{2}$ p. 475 .
${ }^{3}$ Praep. Ev. xiii. I 2.6. 
poem in which St Paul's quotation occurs, and there is evidence to shew that the apostle was not unacquainted with the literature of Jewish Hellenism, whether he had read any pure Greek literature or not $^{1}$. But although it is Aratus who is responsible for the particular words in which St Paul here gives expression to the idea, the conception itself-that of the affinity between God and man-is, as I have said, characteristic not only of Stoicism, but of earlier Greek religious thought, indeed there is perhaps no idea which is more deeply rooted in Greek thought than this; and in order that we may understand its precise significance in the hymn of Cleanthes, as well as on account of the intrinsic importance of the doctrine itself, I will now call your attention to some of the principal stages in the development of this idea before the days of the Stoics.

The first point to notice is that the doctrine in question was by no means alien to the ordinary religious consciousness of Greece, as reflected, for example, in the Homeric poems. Not only in Homer is Zeus the "father of Gods and men," but it is involved in the very nature of anthropomorphic theology that since God resembles man, man in his turn resembles God. From the religious point of view, this is the great merit of anthropomorphismthat it assumes an essential unity between God and man. Anthropomorphism, in a word, involves theomorphism ; and in point of fact, as has frequently been remarked, there is no really essential or ultimate

${ }^{1}$ See Hastings, l.c. s.v. Paul. 
difference between the Homeric god and the Homeric man, except the attribute of immortality: whereas

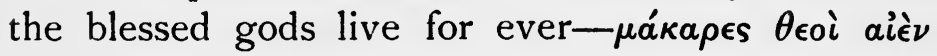

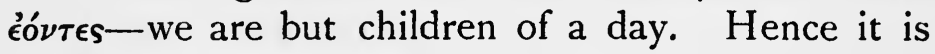
not otherwise than in harmony with the spirit of what we may call orthodox Greek theology when

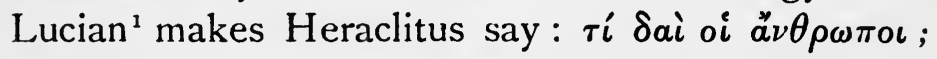

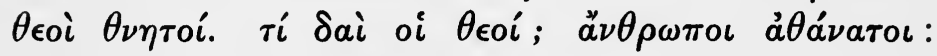
"What are men? Mortal Gods. What are Gods? Immortal men." But in Homer the preponderating stress is laid upon the human attribute of the Gods rather than upon the divine affinities of man; and the same may be said of Hesiod, in spite of occasional hints of the original unity of the divine and human, as for example when he declares that "Gods and mortal men are sprung of the same stock ${ }^{2}$," and again in a fragment preserved by Origen, which tells of the "common feasts and common assemblies" of gods and men in the days of primeval innocence and bliss ${ }^{3}$. Another point to be observed is that in Homer, Hesiod, and the bulk of Greek lyric poetry down to Pindar there is little or no suggestion of a spiritual affinity between man and God: man resembles God, and God is conceived in the image of man, but the resemblance and affinity extend to the outward bodily form as well as to the soul-or rather perhaps, much more than to the soul: for it was only by degrees that the notion of the soul as constituting the true and essential nature of the man came to the

1 Vit. Auct. 14.

2 O.D. 108.

${ }^{3}$ Fr. 187 , Goettling. 
front in Greek thought. Here, as everywhere, the principle holds good: "first the natural, and afterwards the spiritual."

In Pindar's view, as shewn above ${ }^{1}$, it is only the spiritual nature of man, the $\psi v \chi \eta^{\prime}$ or soul, which is declared to be of divine descent. The history of Christian religious thought is enough to prove that Poetry is a most powerful agent in refining and purifying the religious sentiment: I need only refer you by way of illustration to Palgrave's Treasury of Sacred Song. And the same is true of ancient Greece; nor indeed has this inherent power of Poetry ever been better exemplified than by the poet, who throughout his whole career believed himself the chosen servant of Apollo, the most distinctively spiritual of the Greek gods, the god of religious and prophetical, as well as of poetical inspiration.

Although Pindar has not yet shaken himself free from the old Homeric conception of the $\psi v \chi \chi^{\prime}$ as nothing but the shadow of the living self, yet all the emphasis is upon the soul: it is only the spirit or soul of man, says Pindar, that comes from the Gods:

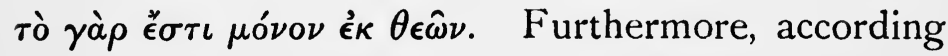
to what the poet here says, in our waking moments the soul is unconscious or asleep; but when the body is laid to rest, the soul awakes and apprehends the future by virtue of its divine affinity, revealing to us the judgment which awaits us after death. What is the theory underlying this conception? Clearly it is

\section{Divine Origin of the Soul.}


nothing but the idea familiar to most of us from the Phaedo of Plato, that the body is as it were the prison-house or tomb of the soul- $\sigma \hat{\omega} \mu \alpha \delta \epsilon \sigma \mu \omega \tau \eta \dot{\eta} \rho \iota \nu$, $\sigma \hat{\omega} \mu a \sigma \hat{\eta} \mu \alpha^{1}$-from which we are set free by the deliverer Death, although sleep, Death's image and twin-sister, sometimes effects a partial resuscitation, a kind of temporary reunion of the soul with the fountain of her being. In somewhat the same way it is said by Plato in the Republic that when we retire to rest after having feasted the rational part of our nature with lofty thoughts, we may, perhaps, in visions of the night apprehend truths greater than we know ${ }^{2}$, the natural divinity of the soul reasserting itself, when temporarily freed from the tyranny of the flesh and its desires. In the literature of the sixth and fifth centuries before Christ, there are not a few traces of this profoundly religious view of the relationship between the soul and the body. We meet with it in the Pythagorean school, in Heraclitus, and in Empedocles, and Euripides gives expression to the same thought in the well-known lines

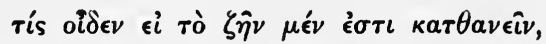

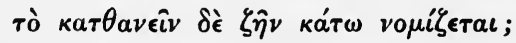

"Who knows if in the world beneath the ground, Life is accounted death, death life? who knows?"3

The general theory of human life and destiny involved in this conception, which is closely allied to

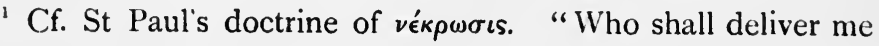
out of the body of this death?" Rom. vii. 24 .

$257 \mathrm{I}$ D.

${ }^{3}$ Fir. 638 , Nauck? 
Buddhism, appears to have been elaborated during the great religious revival, usually known as the Orphic revival, that spread over a large part of Greece during the sixth century B.c. The notion was that life in the body is a penance which the soul, itself originally a God or a portion of the divine essence, has to pay in consequence of ante-natal sin : so that the end of our endeavours is, by the practice of abstinence, by religious ceremonies, and by the cultivation of righteousness and holiness, to keep the soul as far as may be pure from the contamination of the flesh, in order that in due time she may be qualified to rejoin the celestial circle from which she has been exiled $^{1}$. But the point which chiefly concerns us now is that alike in the fragment of Pindar, discussed in the Divine Origin of the Soul, and in the Orphic religious discipline by which that fragment is almost certainly inspired, a clear distinction is drawn between man's bodily nature, which is of the earth, earthy and perishable, and his spiritual nature or soul, which alone is divine, "I am a child of earth and starry heaven"- $\gamma \hat{\eta} s \pi a \hat{i s ~ \epsilon i \mu \iota ~ \kappa a i ~ o u ̉ \rho a \nu o ̂ े ~ a ̉ \sigma \tau \epsilon \rho o ́ \epsilon \nu \tau o s, ~}$ says the soul in one of the Orphic tablets found in S. Italy ${ }^{2}$ : that is, my body is of the earth, my soul from heaven. The religious potentialities of this conception may be seen from the beautiful lines of the Christian poet George Herbert; quoted in the

${ }^{1}$ See G. Murray in Miss Harrison's Proleg. to Gk. Religion, 660-674.

${ }^{2}$ Miss Harrison, l.c. p. 660. 
essay on the Vitality of Platonism, p. 2 I. In this passage the words

"In soul he mounts and flies,

In flesh he dies,"

correspond to the doctrine of $\sigma \hat{\omega} \mu \alpha \sigma \hat{\eta} \mu a$, the body is the tomb; yet flesh is not quite the same as $\sigma \hat{\omega} \mu \alpha$ : it is $\sigma \hat{\omega} \mu a$ tainted by $\sin$.

In Pindar, therefore, the doctrine of man's essential divinity is to a certain extent spiritualised by being restricted to what he calls the soul or $\psi v \times \eta^{\prime}:$ but he seems still to conceive of the soul in the old Homeric way, and he does not, at least in this fragment, give an intellectual interpretation to the doctrine: it is $\psi v \chi \chi^{\prime}$, and not yet $\nu o \hat{s} s$, which he declares to be descended from the gods. There is, however, a remarkable passage in the sixth Nemean ${ }^{1}$ where after an emphatic assertion of the original unity of men and gods- $\hat{\epsilon} \nu$ aे $\nu \rho \hat{\omega} \nu$, $\hat{\epsilon} \nu \theta \epsilon \hat{\omega} \nu$ $\gamma$ Évos-the poet suggests that perhaps the point in which we resemble the immortals is in reality the more intellectual or spiritual part of our nature-mind

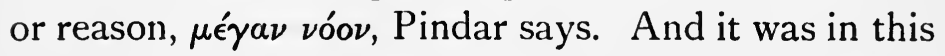
direction that the doctrine of man's celestial origin was developed after the time of Pindar. Thus for example Diogenes of Apollonia, a philosopher who lived at Athens during the latter part of the fifth century before Christ, declared that the vovs or

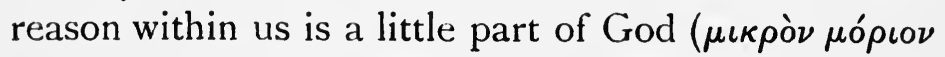
$\tau o \hat{v} \theta \epsilon o \hat{v})^{2}$; and Euripides, influenced no doubt by

1 See supra, Divine Origin of the Soul, p. 39.

2 Diels, Frag. d. Vorsokratiker ${ }^{2}$, i. p. 331, 28.

A. E. 
this philosopher, speaks of the $\nu$ ovs or $\pi \nu \epsilon \hat{v} \mu \alpha$-the human mind or spirit-as akin to the aetherial element which in more than one passage he identifies with Zeus, and as destined at last to be reunited with or reabsorbed into the divine or universal mind from which it came'.

But the thinker who more than any other of the Greeks intellectualised the doctrine of man's divine descent was Plato. In Plato it is always vov̂s or reason which is divine: only we must beware of supposing that he conceived of vovis merely as the kind of siccum lumen, the clear cold light, the unimpassioned analytic and discursive intellect which we are sometimes in the habit of calling reason : it is a religious or spiritual as well as an intellectual faculty in Plato, the link that binds us to the godhead, apprehending the truth not only by means of ratiocination, but also intuitively, in virtue of its affinity with Him who is the truth. Mr Nettleship's observations on Greek philosophy in general are specially applicable to Plato. "We say that Greek moral philosophy, as compared with modern, lays great stress on knowledge, and gives importance to the intellect. That impression arises mainly from the fact that we are struck by the constant recurrence of intellectual terminology, and omit to notice that reason or intellect is always conceived of as having to do with the good. Reason is to Greek thinkers the very condition of man's having a moral being......

${ }^{1}$ Eur. Fr. $94 \mathrm{I}, \mathrm{Hel}$. 1014 ff. quoted supra, Divine Origin of the Soul, pp. 47, 52 . 
Their words for reason and rational cover to a great extent the ground which is covered by words like 'spirit,' 'spiritual,' and 'ideal' in our philosophy. They would have said that a man is a rational being, where we should say that he is a spiritual being ${ }^{1}$." Understood in this way, the doctrine of man's relationship to the divine is perhaps the most fundamental of Plato's doctrines. As I have elsewhere ventured to say, it "is the ultimate source of all his idealism, religious and metaphysical, no less than moral and political, and may well be considered the most precious and enduring inheritance which he has bequeathed to posterity." It would lead us too far from our immediate subject to justify this statement in detail; but before returning to my exposition of Cleanthes, I will quote to you one or two passages in which the founder of idealism in the western world gives expression to the doctrine which has been the watchword of idealism ever since he lived, and I will also point out to you one characteristic and historically fruitful addition which he made to this great doctrine.

You will remember that Plato has two ways of representing that which he calls divine. Sometimes he speaks of the divine in a half-impersonal way, as the Idea or Form, transcendent at once and immanent, eternal, changeless and invisible, the paradigm or type to which the world of generation and

1 Lectures and Remains, ii. p. $22 \mathrm{I}$.

2 Republic of Plato, ii. p. 42. 
decay imperfectly conforms ${ }^{2}$. The totality of Ideas or Forms constitutes a perfectly graduated hierarchy, comparable to the spiritual or angelic hierarchies of patristic and medieval theology ${ }^{2}$; and supreme over all stands the one great unity, which Plato calls the Idea of Good. At other times, again, he uses more obviously religious language, representing the divine as what we should call a personal being, and designating it by the name of God. From Plato's point of view there is not, I believe, any essential or fundamental difference between these two modes of presentation: in other words, the Idea of Good in Plato is God, and God is the Idea of Good: for to Plato philosophy and religion are one and the same thing, and could not be otherwise, inasmuch as God is the supreme truth, and we apprehend him through the divine faculty of reason. Similarly in DanteGod is at once the good, the object of universal desire, the final goal of all particular and immediate striving, and yet at the same time a personal being, the creative cause of all that is. Now whichever of

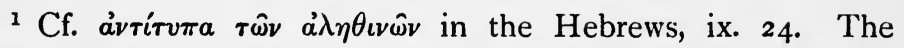
writer of the Hebrews is an "idealist whose heaven is the home of all transcendental realities, whose earth is full of their symbols, and these are most abundant where earth is most sacred-in the temple (or tabernacle) and worship of his people." $\mathrm{He}$ is Alexandrian too "in his frequent contrasts between the invisible, imperishable, archetypal world, and the visible, perishable world of appearance, the imperfect copy ( $\dot{i} \pi \delta \delta_{\epsilon \iota \gamma \mu \alpha)}$ of the former." Massie in Hastings, l.c. s.v. Allegory.

2 See Lightfoot on Col. i. I 6 and cf. Dante, Convito, 11. c. 6 : Paradiso, xxvill. $98 \mathrm{ff}$. 
the two forms of expression-personal or impersonal -we prefer, it is possible to find numerous passages in Plato, where the affinity of the human mind or spirit to the divine is emphatically affirmed. Such passages are to be found in Timaeus $90 \mathrm{ff}$., Phaedo 79 c ff., and especially Republic 50 в B, 589 A, where Plato implies that we are truly human just in proportion as we are divine. This teaching was afterwards worked out by Aristotle and the Stoics; and when Aristotle in the Nicomachean Ethics, x. 7, 9, says that it would seem that the divine or rational part of man is actually the self, inasmuch as it is the supreme or better part of man, it follows that self-realisation, in the true sense of the word, will consist in the cultivation and development of the immortal part of our nature, and the ethical end for man can be expressed in the formula ' $\phi^{\prime}$ ' ó $\sigma o \nu$

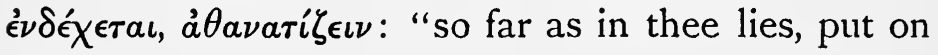
the immortal." The lower merely mortal appetites, that clog and thwart the soul, are alien to our true nature as human beings: by yielding to them we follow a life that is not our own : the way to attain our true and proper individuality is to

"Move upward, working out the beast And let the ape and tiger die ${ }^{1} . "$

On the deeper religious and philosophical significance of this great doctrine of man's ideal and essential unity with God, the history of which I have

'For a fuller discussion of this subject see supra, Divine Origin of the Soul, pp. $62 \mathrm{ff}$. 
thus briefly traced from Pindar down to Aristotle, I will not on this occasion dwell. It is admirably brought out by Principal Caird in his Gifford lectures on The Fundamental Ideas of Christianity, a book which I would ask you to read as a sequel to these lectures. It may however be noted that according to St Paul the highest element in man, which he terms $\pi \nu \epsilon \hat{v} \mu a$, is the part of our nature by which we are allied to God, and that he sometimes denotes this principle by the Platonic term vovs, which means the $\pi \nu \epsilon \hat{v} \mu a$ seeking to apprehend divine things ${ }^{1}$. What concerns us chiefly at present is to understand its significance in Stoicism; and on this subject I will now say a few words, at the same time recommending you to study the meditations of Marcus Aurelius, translated by Rendall, and the discourses of Epictetus, in $\mathrm{Mr}$ Long's translation. After what has hitherto been said, you will readily understand that in pronouncing man to be the offspring of God-ék $\sigma o \hat{v}$ $\gamma \grave{a} \rho \gamma \epsilon \nu$ ó $\mu \epsilon \sigma \theta \alpha$-Cleanthes means simply that the intellectual and spiritual part of our nature, that is to say, our $\nu$ ovs or reason, is in the fullest sense of the term divine, a fragment or efflux, as the Stoics frequently maintained, of God. This is a cardinal doctrine of Stoic anthropology, from Zeno ${ }^{2}$ down to Marcus Aurelius ; but it is much more prominent in later than in earlier Stoicism, and for that reason most of my illustrations will be drawn from Epictetus

1 See Adam, Religious Teachers of Greece, p. 381 f.

${ }^{2}$ See e.g. Fragment 95 in Pearson's Fragments of Zeno and Cleanthes. 
and his pupil the Roman Emperor. Marcus Aurelius never wearies of ringing the changes on this idea. "God sees men's Inner Selves stripped of their material shells and husks and impurities. Mind to mind, his mental being touches only the like elements in us derivative and immanent from him ${ }^{1}$." Elsewhere he speaks of the "God" or "daemon" or "divine element" within us 2 , "my God and daemon"," the spirit which is "mind and God," whereas the body is but " refuse clay," and identifies the spirit with the true self, the inner man or ego, that part of our nature which alone can truly be called our own ${ }^{5}$. "That which pulls the strings, remember, is the power concealed within; there is the mandate, the life, there, one may say, the man. Never confound it with the mere containing shell, and the various appended organs. They may be compared to tools, with this difference, that the connexion is organic. Indeed, apart from the inner cause which dictates action or inaction, the parts are of no more use than the weaver's shuttle, the writer's pen, or the coachman's whip'."

Let us now consider some of the implications which this doctrine carries with it in Stoicism. What bearing has the belief in man's celestial origin and kinship upon his conception, first of the duty he owes to himself, and secondly of the duty he owes to his fellow-men? I will take these two points separately.

\footnotetext{
${ }^{1}$ XII. 2, tr. Rendall.

3 v. Iо.

4 III. 3 , tr. Rendall.

2 II. I3, III. 5, XI. I9 al., XII. I.

${ }^{6}$ x. 38 , tr. Rendall.
} 
First then, as to the duty we owe to ourselves. The keynote of Stoic morality, so far as concerns the individual in his relation to himself, is contained in the following passages of Epictetus. "If a man should be able to assent to this doctrine as he ought, that we are all sprung from God in one especial manner, and that God is the father both of men and of gods, I suppose that he would never have any ignoble or mean thoughts about himself. But if Caesar (the emperor) should adopt you, no one could endure your arrogance; and if you know that you are the son of Zeus, will you not be elated? Yet we do not so; but since these two things are mingled in the generation of man, body in common with the animals, and reason and intelligence in common with the gods, many incline to this kinship, which is miserable and mortal ; and some few to that which is divine and happy. Since then it is of necessity that every man uses everything according to the opinion which he has about it, those, the few, who think that they are formed for fidelity and modesty and a sure use of appearances have no mean or ignoble thoughts about themselves; but with the many it is quite the contrary. For they say, What am I ? A poor, miserable man, with my wretched bit of flesh. Wretched, indeed; but you possess something better than your bit of flesh. Why then do you neglect that which is better, and why do you attach yourselves to this'?" "Nevertheless he" (that is, Zeus) "has placed by every man a guardian, 
every man's Daemon, to whom he has committed the care of the man, a guardian who never sleeps, is never deceived. For to what better and more careful guardian could he have intrusted each of us? When then you have shut the doors and made darkness within, remember never to say that you are alone, for you are not; but God is within, and your Daemon is within, and what need have they of light to see what you are doing? To this God you ought to swear an oath just as the soldiers do to Caesar. But they who are hired for pay swear to regard the safety of Caesar before all things; and you who have received so many and such great favours, will you not swear, or when you have sworn, will you not abide by your oath? And what shall you swear? Never to be disobedient, never to make any charges, never to find fault with anything that he has given, and never unwillingly to do or to suffer anything that is necessary. Is this oath like the soldier's oath ? The soldiers swear not to prefer any man to Caesar: in this oath men swear to honour themselves before all'". Side by side with these two passages set the following from Marcus Aurelius: "Live with the gods ( $\sigma v \zeta \hat{\eta} \nu \theta \epsilon o \hat{\imath})$. And he lives with the gods, whoever presents to them his soul acceptant of their dispensations, and busy about the will of God, even that particle of Zeus, which Zeus gives to every man for his controller and governor-to wit, his mind and reason"." You will see that from one point of view the God within us, that is, our mind or spirit, appears

$$
{ }^{1} \text { I. I 4, tr. Long. } \quad 2 \text { v. } 27 \text {, tr. Rendall. }
$$


as an internal oracle, a guide whom we are to follow:

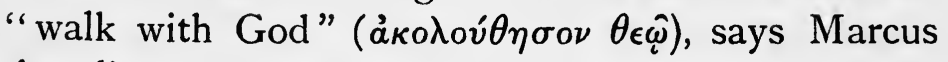
Aurelius ${ }^{1}$. With this may be compared Heraclitus'

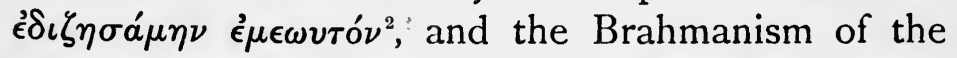
Upanishads, as exemplified in the following lines:

"Whoso shall find him the awaken'd Self, that lodgeth in this darkling patch'd-up house, builder of all is he, the All he maketh; his is the world, the world in sooth is he. When straightway he beholdeth god in Self sovran of what hath been and is to be, his thought no more shall waver in its ways."

From another point of view this divine faculty may be regarded as conscience: "God is near thee," we read in Seneca, "with thee, within thee...there dwells in us a holy spirit (sacer intra nos spiritus sedet), to keep watch and ward over our good and evil deeds (malorum bonorumque nostrorum observator et custos)." To the same effect Epictetus writes: "When we are children our parents deliver us to a paedagogue to take care on all occasions that we suffer no harm. But when we are become men,

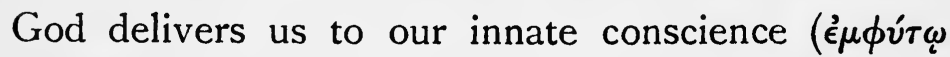
$\sigma v \nu \epsilon \iota \delta, \sigma \epsilon \iota)$ to take care of us. This guardianship then we must in no way despise, for we shall both displease God and be enemies to our own conscience ${ }^{5}$."

Or again the divine particle within us is represented as a treasure or talent committed to our

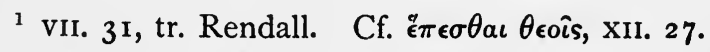

${ }^{2}$ Fr. 80. ${ }^{3}$ Barnett, Hinduism, p. 16. ${ }^{4}$ Ep. 41. 2.

${ }^{5}$ Fr. 97 , tr. Long. Doubts have been held as to the authenticity of this fragment; but in sentiment, at least, it is Stoic. 
charge. "Keep the deity within inviolate and free from scathe"." "Keep your God within pure and erect, as though at any moment liable to be recalled"." Man's duty is "to keep the god implanted in his breast unsoiled, not perturbed by any tumult of impressions, keeping his watch serene, a seemly follower of god, not false to truth in utterance or to justice in act $^{3}$." Passages such as these have often been compared with the words of St Paul: "Know ye not that ye are a temple of God, and that the spirit of God dwelleth in you"?" "Know ye not that your body is a temple of the Holy Ghost which is in you, which ye have from God" ?" and it is certain, not only that a Stoic might quite well have used this language, but also that the ethical motive to which the Apostle here appeals-honour the divine element within you-plays a very great part in later Greek Stoicism. But when St Paul continues: "and ye are not your own; for ye were bought with a price ${ }^{6}$ - he adds a new and far more powerful motive, a motive which, as will afterwards be pointed out, is the one great and fundamental difference between Christianity on the one hand, and Greek philosophy upon the other, the stimulus of a divine yet human personality, in whose death we live by dying unto sin.

Finally, the divine element within us is sometimes conceived of by the Stoics as a kind of God-given

1 II. I 7, tr. Rendall.

3 III. I6, tr. Rendall.

5 Ibid. vi. 19.
III. I 2, after Rendall.

4 I Cor. iii. 16.

- Ibid. 
seed or germ, which it is our privilege and duty to cultivate and develop. "It suffices," says Marcus Aurelius", "to attend only to the daemon within oneself and truly cultivate it." The Stoics were no believers in pre-existence, as pre-existence was understood by Plato ; but if Epictetus and others may be trusted, neither did they hold that the mind is at birth no more than a tabula rasa, a blank sheet of paper for the registration merely of sense-impressions: nor indeed could such a view have possibly been entertained by those who regarded the human mind as from the first a portion of the divine. On the contrary, according to the express statement of Epictetus, we have certain "innate notions" on such subjects as good and evil, honourable and base, the becoming and the unbecoming, what we ought to do and what we ought not to $\mathrm{do}^{2}$, etc. These "innate notions" were called in Stoicism ${ }^{\prime} \mu \phi v \tau o \iota \pi \rho \circ \eta \dot{\eta} \psi \epsilon \iota$ : and they were strictly limited to the domain of morality, aesthetics and religion: thus, for example, we have no $\ddot{\epsilon}_{\mu} \phi v \tau o s \quad \pi \rho o ́ \lambda \eta \psi \iota s$ of a right-angled triangle, but the notion of God's existence, on the other hand, is innate ${ }^{3}$. At first, however, these ideas are undeveloped and obscure-obscurae, adumbratae intellegentiae, Cicero calls them, notitiae parvae rerum maximarum tanquam elementa virtutis ${ }^{4}$; and it is only after they have been articulated ( $\delta \iota \eta \rho \theta \rho \omega \mu \epsilon_{\nu} \nu \iota$ $\left.\pi \rho \circ \lambda \eta^{\prime} \psi \epsilon \iota\right)$ by self-conscious, reflective thought that

1 II. I 3.

2 II. II.

3 Ibid. and Cic. N. D. II. I 2 and 45.

4 Laws, I. 26 and 59: De Fin. v. 59. 
they begin to have a positive value ${ }^{1}$. In this way the moral progress of the individual becomes a process of emulation or development of what is already present in the mind by reason of its divine affinity, in other words a process of self-realisation, the word self being understood as usual of the inner or higher self, that is the human nature in so far as it is also divine. Self-realisation is one of the cardinal principles of Stoic ethics.

$\mathrm{Up}$ to this point, I have spoken only of the way in which the Stoic teachers' conception of man's affinity with God affected their view of what may be called personal morality. But, it may fairly be asked, was morality, then, in Stoicism, only self-regarding? This is a reproach which has often been brought against the system; and we must allow that there is reason for such a reproach in the somewhat academic pictures which they often draw of the wise man-the ideal type of perfect virtue, perfect apathy (in the classic meaning of the word), and perfect selfsufficiency. If we turn, however, to the works of Epictetus and Marcus Aurelius-and the spirit which animates these writers is altogether in keeping with the latter half of Cleanthes' hymn-we shall find that the Stoic conception of self-realisation or self-culture was not and could not possibly be purely selfish or self-regarding, just because the self which the Stoic endeavours to realise is essentially the universal, and not what we should call the individual self at all.

${ }^{1}$ See on the whole subject Bonhöffer, Epictet u. die Stoa, I $87 \mathrm{ff}$. 
The divine faculty of reason is not the monopoly of the wise man: it exists in every human being, the pledge of our common brotherhood, the proof of the universal fatherhood of God. Marcus Aurelius is always reiterating the doctrine that man's brotherhood with all mankind depends not on "blood or the generative seed, but on community in mind" ( $\nu$ ô

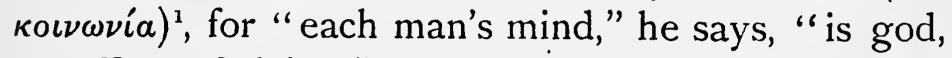
an efflux of deity?" It follows that the ideal man never "forgets his bond of brotherhood with every rational creature" : "for it is the distinctive property of a rational being to love his neighbours." "We are made for co-operation," says Marcus Aurelius ${ }^{5}$, "like the feet, the hands, the eyelids, the upper and the lower rows of teeth." "You are part of a social whole, a factor necessary to complete the sum; therefore your every action should help to complete the social life. Any action of yours that does not tend, directly or remotely, to this social end, dislocates life and infringes its unity. It is an act of sedition, and like some separatist doing what he can to break away from civic accord ${ }^{6}$." Hence the Stoic conception of self-realisation, so far from being monastic, can only be attained through the service of others. "No one outside the pale of Christianity," says Mr Dill, "has perhaps ever insisted so powerfully on the obligation to live for others...as Seneca has

1 XII. 26.

2 Ibid. tr. Rendall.

3 III. 4, tr. Rendall.

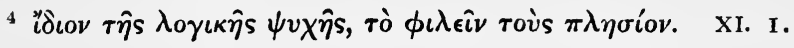

5 II. I, tr. Rendall.

6 IX. 23 , tr. Rendall. 
done." And in this respect Seneca is but the representative of later Stoicism. "Man is made for kindness," we read in Marcus Aurelius, "and whenever he does an act of kindness or otherwise helps forward the common good, he thereby fulfils the law of his being and comes by his own"." And in another passage "Do that which reason, your king and lawgiver suggests for the help of men ('ं $\pi^{\prime} \omega^{\prime} \phi \epsilon \lambda \epsilon i a$ $\left.a^{3} \nu \theta \rho i \pi \omega \nu\right)^{3} . "$ It is all summed up in a single pregnant text of Marcus Aurelius: $\phi \hat{\lambda} \lambda \eta \sigma o \nu$ tò

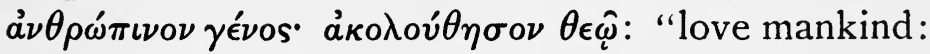
walk with God"." You cannot walk with God, unless you love mankind.

The highest expression of what may be called the social side of Stoicism is the doctrine of worldcitizenship, for which the teaching of Socrates and Plato had already prepared the way. It is a favourite Stoic idea that the world is a $\mu \epsilon \gamma a ́ \lambda \eta \pi$ ó $\iota s$, a great city, whose citizens are men and gods-men being as it were the children, and God the universal father ${ }^{5}$. "Est enim mundus," says Cicero, "quasi communis deorum atque hominum domus aut urbs utrorumque." Within this great community the earlier Stoics, it is true, recognised a narrower and more exclusive commonwealth, analogous in some

' Roman Society from Nero to Marcus Aurelius, p. 326.

2 IX. 42 , tr. Rendall. $\quad{ }^{3}$ IV. I 2, tr. Rendall.

4 viI. 3 I, tr. Rendall.

5 We are as it were $\pi a \hat{i} \delta \epsilon \varsigma \sigma \dot{v} v a \dot{a} \delta \rho \alpha \dot{\sigma} \iota$ in the World-City. See Von Arnim, Stoicorum veterum fragmenta, III. 334.

- De Nat. Deor. II. I 54. 
respects to the conception of a church, and embracing only the good or wise. "Only good men," said Zeno, "are fellow-citizens and friends and relations and free men" : between fools or sinners there is nothing but enmity ${ }^{2}$. But, owing in some degree to the fact that the Stoic wise man always remained an unrealisable aspiration or ideal, the commonwealth of the wise plays a comparatively small part in practical as opposed to theoretical Stoicism; and in Epictetus and his pupil it is nearly always the wider and more comprehensive ideal that prevails. "In so far as I am Antoninus," said Marcus, "my city and fatherland is Rome, but as a human

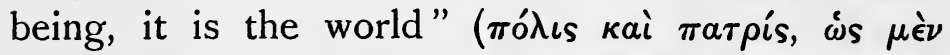

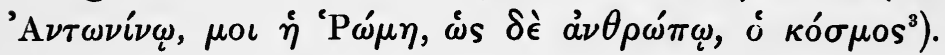
In Epictetus, again, we read "If the things are true which are said by the philosophers about the kinship between God and man, what else remains for men to do than what Socrates did? Never in reply to the question, to what country you belong, say that you are an Athenian or a Corinthian, but

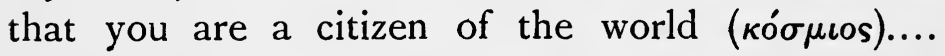
$\mathrm{He}$ then who...has learned that the greatest and supreme and the most comprehensive community is that which is composed of men and God, and that from God have descended the seeds not only to my father and grandfather, but to all beings which are generated on the earth and are produced, and particularly to rational beings - for these only

\footnotetext{
1 Fr. 149, Pearson.

${ }^{3}$ VI. 44 .
}

2 Ibid. 154 . 


\section{Universal brotherhood}

are by their nature formed to have communion with God, being by means of reason conjoined with him-why should not such a man call himself a citizen of the world, why not a son of God ${ }^{1}$ ?" In this great commonwealth, slaves as well as freemen participate, sinners as well as saints. Writing against the inconsiderate treatment of slaves, Epictetus observes: "Slave yourself, will you not bear with your own brother, who has Zeus for his progenitor, and is like a son from the same seeds and of the same descent from above?...Will you not remember who you are, and whom you rule? that they are kinsmen, that they are brethren by nature, that they are the offspring of Zeus ${ }^{2}$ ?" And Marcus Aurelius for his part speaks of the sinner as a brother, "participating not indeed in the same flesh and blood, but in the same mind and partnership with the divine ${ }^{3}$ ": they err unwillingly, he says, through ignorance": "teach them then, or bear with them." Tout savoir, c'est tout pardonner. With this we may compare the following fragment. "A pirate had been cast on the land and was perishing through the tempest. A man took clothing and gave it to him, and brought the pirate into his house, and supplied him with everything else that was necessary. When the man was reproached by a person for doing kindness to the bad, he replied, I have shown this regard not

1 I. 9, tr. Long.

3 II. I, tr. Rendall.

5 vili. 59, tr. Rendall.
2 I. I3, tr. Long. Cf. Dill, l.c. p. 328. 4 Iv. 3.

A. E. 
to the man, but to mankind ${ }^{1 . " ~ I f ~ w e ~ w o u l d ~ u n d e r-~}$ stand the true historical significance of the Stoic cosmopolitanism, we must above all things remember that it is essentially a religious ideal, since the bond of citizenship is man's unity with man in virtue of his unity with God. It is the prototype, and so far as Greek thought is concerned, in part at least the progenitor of the Christian civitas dei or "city of God." In Marcus Aurelius we have the very phrase: " 'Dear city of Cecrops!' saith the poet, and wilt thou not say 'Dear city of God"'?" We have a kind of unconscious prophecy in a noble fragment of Cicero's de republica, a fragment inspired by what is best and most enduring in the philosophy of Plato and the Stoics: "And there will not be one law at Rome and another at Athens, one law to-day and another law to-morrow; but the same law everlasting and unchangeable will bind all nations at all times; and there will be one common Master and Ruler of all, even God, the framer, the arbitrator, and the proposer of this law. And he who will not obey it will be an exile from himself, and, despising the nature of man-naturam hominum aspernatus-will, by virtue of that very act, suffer the greatest of all penalties, even though he shall have escaped all other punishments which can be imagined ${ }^{3}$." Christianity has done something to

1 Pseudo-Epictetus, Fr. 109, tr. Long.

2 IV. 23, tr. Rendall.

3 III. c. 22, tr. Churton Collins (Studies in Shakespeare, p. 127 ). 
bring this ideal nearer; but it can only be fully realised when the prayer is fulfilled: "Thy kingdom come. Thy will be done on earth, as it is in heaven ${ }^{1 . "}$

Enough has now been said by way of expounding and illustrating the doctrine of man's divine descent as it appears not only in Stoicism but also in earlier Greek literature. Let us now proceed to discuss the second division of the hymn. We shall find it, I think, equal in point of interest and importance to the first.

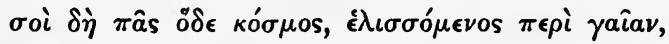

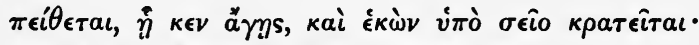

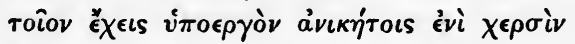

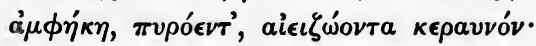

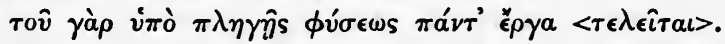

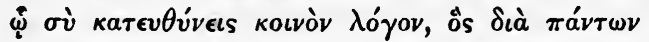

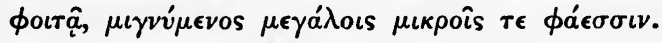

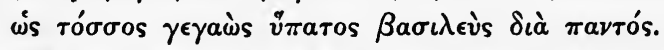

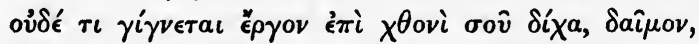

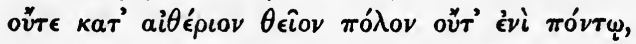

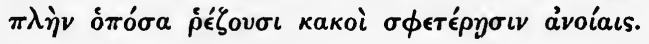

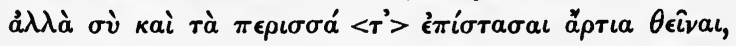

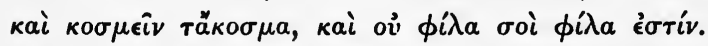

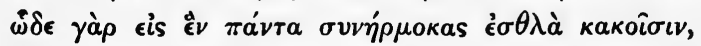

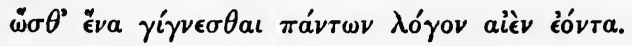

"Lo! yonder Heaven, that round the earth is wheeled, Follows thy guidance, still to thee doth yield Glad homage; thine unconquerable hand Such flaming minister, the levin-brand

${ }^{1}$ Cf. Dill, l.c. p. 328: "The Stoic school has the glory of anticipating the diviner dream, yet far from realised, of a human brotherhood under the light from the Cross." 
Wieldeth, a sword two-edged, whose deathless might

Pulsates through all that Nature brings to light;

Vehicle of the universal Word, that flows

Through all, and in the light celestial glows

Of stars both great and small. O King of kings

Through ceaseless ages, God, whose purpose brings

To birth, whate'er on land or in the sea

Is wrought, or in high heaven's immensity;

Save what the sinner works infatuate.

Nay, but thou knowest to make crooked straight:

Chaos to thee is order: in thine eyes

The unloved is lovely, who didst harmonise

Things evil with things good, that there should be

One Word through all things everlastingly."

The general idea running through these lines is that the whole of external Nature, organic and inorganic, yields implicit obedience to the law of God; and if we look at them in connexion with the next division of the poem (extending from line 22 to line 35), we shall see that one of the objects of Cleanthes is to contrast Nature's obedience with man's disobedience. For a Christian parallel we may compare the lines of Henry Vaughan :

"Sometimes I sit with Thee, and tarry

An hour or two, then vary.

Thy other creatures in this scene

Thee only aim, and mean;

Some rise to seek Thee, and with heads

Erect, peep from their beds;

Others, whose birth is in the tomb,

And cannot quit the womb,

Sigh there, and groan for Thee,

Their liberty.

I would I were a stone, or tree,

Or flower by pedigree, 
Or some poor highway herb, or spring

To flow, or bird to sing!

Then should I-tied to one sure state-

All day expect my date;

But I am sadly loose, and stray

A giddy blast each way;

$O$ let me not thus range!

Thou canst not change ${ }^{1 . "}$

But the verses of Cleanthes need elucidation in nearly every detail. I will first endeavour to explain their meaning in such a way as to disentangle the principal ideas which they express: and afterwards I will discuss and illustrate these ideas at greater length.

"Then all this universe, circling around the earth, obeys, following thy guidance, and willingly accepts thy rule: such a minister hast thou in thine unconquered hands, two-edged, firefraught, the ever-living thunderbolt: for under its pulsations all the works of nature are accomplished. Therewith thou directest the universal Word, that moves through all things, mingling with the great and lesser lights."

We have here, you will observe, three apparently distinct conceptions-first the supreme God or Zeus, who is addressed throughout: second the ever-living thunderbolt, his minister: and thirdly,

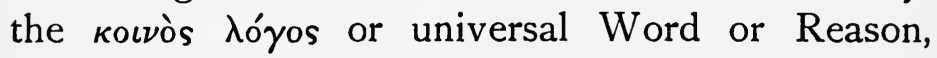
represented as carried to and fro throughout the world by means of the thunderbolt as the shuttle carries the thread. In reality, however, the thunderbolt and the Universal Word are not numerically separate either from the supreme God or from

${ }^{1}$ Creation waiting for Deliverance (Palgrave, Treasury of Sacred Song, p. 9r). 
one another: they are only two different aspects, in which the highest Unity reveals himself to us, two mutually complementary points of view from which the human intellect regards him ${ }^{1}$. We must not forget that Stoicism is a monistic and not a dualistic system: to the Stoic there is nothing outside God, who is the universe or all: what we call matter and what we call spirit are a unity in him. What then does the poet mean by the "everliving thunderbolt"? This oracular phrase is taken from Heraclitus, who in one fragment speaks of the "ever-living fire ${ }^{2}$," and in another says that "the

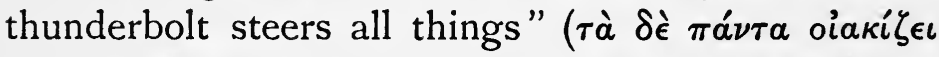
$\kappa \epsilon \rho a v \nu o ́ s)^{3}$. Now in Heraclitus "the thunderbolt" is only a poetical synonym for the material aspect of the $\gamma \nu \omega^{\prime} \mu \eta$ or $\lambda o^{\prime} \gamma o s$, the thought that interpenetrates and rules the world; and similarly in Cleanthes, the "ever-living thunderbolt" means the immanent, omnipresent Godhead regarded on what may be called his material or physical side. The Stoics, indeed, sometimes go so far as to identify the Deity with a species of fire, exactly as Heraclitus appears to have done: one of their definitions of God is "creative fire, proceeding systematically to the generation of the world" ; that is to say,

${ }^{1}$ Just so in the Timaeus of Plato, the $\delta \eta \mu$ rovprós is not to be viewed as distinct from the Idea on the model of which he frames the world: he is that Idea, regarded in its creative or movent aspect.

2 Fr. 20.

8 Fr. 28.

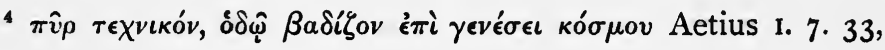
p. 306, Diels. 
evolving the world from himself according to the unalterable law of his own being; although, when speaking more exactly, they prefer to use the word "aether" of the divine substance-a curious anticipation, by the way, of recent theories of the structure of matter. A further point deserving of notice in connexion with the expression "everliving thunderbolt" is this. We have seen that the Stoics spared no effort to reinterpret the popular religion in terms of their own philosophy, by the extensive use of allegory; and you will remember that the thunderbolt is always in Greek poetry and art the emblem of Zeus: nay more, Zeus was worshipped as God of the thunderbolt (Z€ìs $\kappa \epsilon-$ pav́vios), and sometimes as the thunderbolt itself (Zeìs $\kappa \epsilon \rho a v \nu o^{\prime}{ }^{1}$ ). Thus, while following his master Heraclitus, Cleanthes at the same time contrives to give a philosophical interpretation, as philosophers are wont to do, to a familiar article of the popular creed.

The phrase "beneath whose pulsations all the works of Nature are accomplished," is an allusion to the characteristically Stoic doctrine of róvos, that is, a certain intrinsic tension or strain present in the original divine substance out of which the universe is formed, a doctrine about which I will only say now that it is another curious foreshadowing of certain modern theories of the constitution of the atom. Passing over this subject, let us consider what Cleanthes wishes us to understand by the roıvòs

1. In Mantinea. See Farnell, Cults of the Greek States, I. p. 45. 
$\lambda$ óyos, the universal word or reason that "moves through all things, mingling with the great and lesser lights." As the "thunderbolt" expresses the material, so the "universal word" expresses what we should call the spiritual aspect of the immanent, omnipresent Godhead. We are told by Tertullian that Cleanthes conceived of the $\lambda$ óyos as a spiritus permeator universitatis-a spirit permeating the universe ${ }^{1}$; and another authority informs us that he considered God to be the soul of the world $\left(\tau \grave{\eta} \nu \text { rov } \kappa o ́ \sigma \mu o v \psi v \chi \hat{\eta}^{\prime} \nu\right)^{2}$. Here, then, we have the great doctrine of the Logos in its Greek form-a doctrine which, as I hope to show you presently, reaches back to Heraclitus, and forward to St John, although in the fourth Gospel it doubtless owes something to Hebrew influence, and is undoubtedly transformed and transfigured by the introduction of an element which is neither Greek nor Hebrew, but in the true and etymological meaning of the word, exclusively Christian.

The lines that follow touch incidentally on the question of free-will and moral responsibility: "Nor is aught done without thy will, $O$ Lord, on earth, or in the aetherial firmament divine, or in the sea, except what evil men do through their own folly": and thereafter we have a profoundly religious characterisation of the Godhead as the Harmony in whom all discord, both physical and moral, is reconciled. "Nay, but thou knowest also how to make odd even, and bring order out of chaos; and the unloved is loved by thee. For thou hast joined together into

1 Cleanthes, Fr. I 2, Pearson. 2 Fr. 14. 
one whole all things good with all things evil, in such a way that all make up one universal Word, existent evermore."

The topics which have emerged in this somewhat rapid survey of the second division of the hymn are three in number. There is first, the immanence of God in the world : secondly, the conception of God as the discors concordia rerum-the cosmic harmony in which all partial discords are comprehended and conciliated : and finally, we have the question of free-will, with all that it involves about the origin of moral evil in the world. The last of these topics can best be dealt with as an appendix or epilogue to the other two; and the two first are only somewhat slightly different phases of the Logos doctrine, the full meaning and significance of which I will now endeavour to expound.

Here, as formerly, we must begin with Heraclitus. We are expressly told by Clement of Alexandria that Heraclitus declared fire to be $\mathrm{God}^{1}$; and although none of the extant fragments affirms the identity in so many words, it can be shown, I think, that this omnipresent rational fire which he calls $\lambda$ óros is in point of fact Heraclitus' conception of the Godhead'. It would lead us too far to trace the history of the doctrine of the divine immanence in Greek literature from Heraclitus down to the Stoics; and I must content myself with saying that it under-

'Coh. ad Gent. 5. 165 A, Migne.

${ }^{2}$ For a full discussion of the steps by which this conclusion is reached, see supra, The Doctrine of the Logos in Heraclitus, pp. 79 ff. 
went the usual process of spiritualisation- "first the natural and afterwards the spiritual"-through the influence of poetry and philosophy ${ }^{1}$ - until we meet with it in an altogether dematerialised or spiritual form in the Platonic theory of the cosmic or world soul. It should also be remarked that whereas in Heraclitus God is conceived of only as immanent and not as transcendent, in conformity with the usual trend of pantheistic theology, Plato on the other hand represents the world-soul as distinct from the Creator or supreme God, as it were his vicegerent in the world of space and time, an emanation, as it would seem, from his own transcendence; and thus the Platonic form of the doctrine satisfies the two essential conditions of theism, according to which the Godhead is at once transcendent and immanent. The Stoics, as we have seen, reverted to Heraclitus in both particulars, affirming only the immanence of God in thcir doctrine of the omnipresent Logos, and denying the duality of matter and spirit through their identification of the Logos with $\pi \nu \epsilon \hat{v} \mu \alpha$ " $\nu \theta \epsilon \rho \mu o \nu$, "warm breath" or "aether." Let me endeavour to show you in a little more detail how this conception of the divine immanence and omnipresence was worked out by Stoicism,

1 See especially the fragments of Epicharmus, ed. Kaibel. In Euripides, too, we have a kindred conception: see Adam, Religious Teachers of Greece, pp. 299 ff. : and something of the same kind meets us in Anaxagoras, Diogenes of Apollonia (in whom, however, the materialism reappears), and in Socrates: ibid. pp. 26 If ff, 266 f., 348 f. 
before I proceed to remark upon its religious meaning and value.

The all-pervading Deity or world-soul or Logos -for these different designations, together with many others, such as Justice, Providence and Fate, are practically synonymous, or at most express but different ways in which the human mind conceives of the divine unity - this all-pervading Godhead was regarded by the Stoics as a spirit or $\pi \nu \epsilon \hat{v} \mu a-a$ kind of "atmospheric current" present in every form of matter, whether organic or inorganic : but the degree of tension or strain persisting in the $\pi \nu \epsilon \hat{v} \mu a$-the

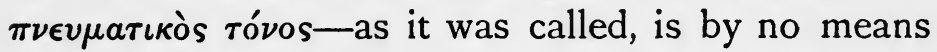
the same throughout. Where the tension is least, as in inorganic objects, stones, for example, minerals, pieces of earth, wood and so forth, the $\pi \nu \epsilon \hat{v} \mu a$ appears as a kind of current ( $\pi \nu \epsilon v \mu a \tau \iota \kappa o ́ \nu \tau \iota)$ streaming from the centre to the extremities of the object and back again to the centre, with power to hold the thing together, but with no power to make it move. This, which is the lowest grade of $\pi \nu \epsilon \hat{v} \mu a$, though still, of course, a revelation of the Godhead, the Stoics called $\xi^{\prime} \xi$ is or "cohesion," because it possesses

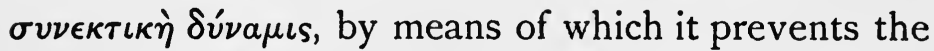
object from falling to pieces. We must not call it soul, but it is the substitute for soul in inorganic things. Next higher in the scale comes $\phi \dot{v} \sigma \iota s$ or "Nature," which is so to speak the soul of plants, the word "Nature" being used in a highly technical or scientific sense, with a play of course on $\phi v \tau o$ v "plant." Here the tension of the $\pi \nu \epsilon \hat{v} \mu \alpha$ is greater, 
involving the power of movement, upward and downward movement at least, together with such other attributes or qualities as belong to the life of plants. It is not until we reach the third stage in the ascent that we meet with $\psi v \chi \eta^{\prime}$ or soul, which is the form in which the $\pi \nu \epsilon \hat{v} \mu a$ reveals itself in the lower animals. Finally, when man is reached, we have rational soul or $\nu$ ovs, the form of $\pi \nu \epsilon \hat{v} \mu \alpha$ in which the tension is highest, for, as we have already seen, man's $\nu$ ov s is in a peculiar and distinctive sense a portion of God.

Now in this ascending scale of existences I would have you particularly observe that each higher grade includes and embraces all the lower: minerals have

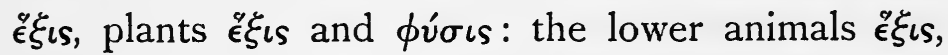
$\phi \dot{v} \sigma \iota s$ and $\psi v \chi \chi^{\prime}:$ and man $\epsilon^{\epsilon} \xi \iota s, \phi \dot{v} \sigma \iota s, \psi v \chi \eta^{\prime}$ and

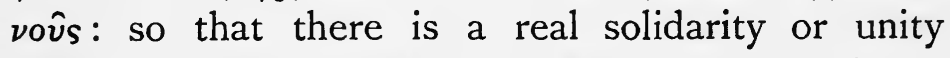
stretching "through all the mighty commonwealth of things," not merely, as Wordsworth says,

"Up from the creeping plant to sovereign man"

but from the lowest creations of even inorganic nature up to sovereign man: for God according to the Stoics is present even in the most ignoble forms of matter. In this way God is the true $\epsilon^{\prime} \nu \omega \sigma \iota s$ $\tau$ v kó $\sigma \mu o v$, the "unity" or "unification of the world," in the language of Cleanthes, the universal Word or Reason

"that flows

Through all, and in the light celestial glows

Of stars both great and small"; 
"even as"-to quote again from Wordsworth,

$$
\text { "one essence of pervading light }
$$

Shines in the brightest of ten thousand stars

And the meek worm that feeds her lonely lamp

Couch'd in the dewy grass ${ }^{1}$."

From the considerations which I have now placed before you, it will be evident to you all that the Stoics found a revelation of God in nature as well as in the heart of man. Anyone who wishes to follow out their treatment of this subject in detail cannot do better than read the de natura deorum of Cicero in Professor Mayor's edition-one of the most interesting and suggestive treatises on natural theology ever written. It would be a fascinating enquiry to trace the parallels between the Stoic and the early Christian conceptions of the divine immanence, more especially the Johannine interpretation of the Logos as the "timeless life, of which the temporal world is a manifestation "," but on the present occasion I will rather call your attention to the way in which the Stoic deification of Nature reappears in certain types of modern half-religious and halfphilosophical poetry, making mention, however, by the way, of what seems to me a really striking

1 Prelude, Book xiv. See also especially Critolaus in von

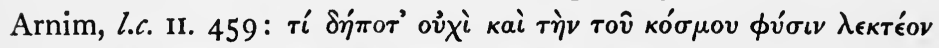

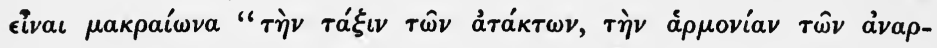

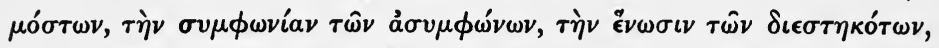

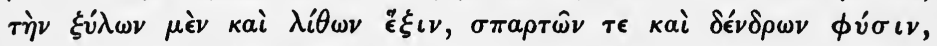

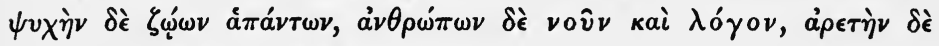

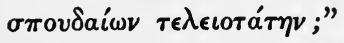

${ }^{2}$ Inge, Christian Mysticism, p. 46. 
example of the influence exerted by Stoicism on primitive Christian thought. In the fifth of the sayings of Jesus discovered in I 897 we read: "Jesus saith, wherever there are [two], they are not without God, and wherever there is one alone, I say, I am with him. Raise the stone, and there thou shalt find me; cleave the wood and there am I." It is impossible for anyone who is familiar with Stoicism to read this Logion without thinking at once of the Stoic conception of the omnipresent Logos, although in Christianity of course the Logos has become incarnate in the person of Christ. I would venture also to suggest that the second of the five additional sayings discovered at Oxyrhynchus in 1903 cannot be fully understood, except in connexion with the Stoic doctrines which I have described. I will quote the Logion according to Professor Swete's restoration, except in one passage, where I follow Grenfell and Hunt: "Jesus saith, who are those that draw you to the kingdom? The kingdom is in heaven. They that are upon the earth and the fowls of the air and every creature that is under the earth and in Hades and the fishes of the sea-these are they which draw you. And the kingdom of heaven is within you, and whoever shall know himself shall find it. For if ye shall truly know yourselves, ye will also know ${ }^{1}$ that ye are sons of the almighty Father; and ye shall know that ye are within the city, and ye are the city." Without pursuing the subject into details, it will suffice to say

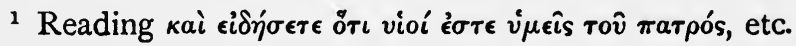


that we have here, as it seems to me, an early Christian version of two great Stoic doctrines-the presence of God in every species of living creature throughout the world, pointing us to the Father divine from whom we also come, and the presence of God in a yet still more intimate sense within ourselves, so that to know ourselves is to know the Father and our relationship to $\mathrm{Him}$.

Premising that the indwelling, omnipresent, Deity of the Stoics is from one point of view identical with Nature ${ }^{2}$-and indeed they sometimes defined God and Nature in exactly the same terms ${ }^{2}$, let us now turn our attention for a little to the poetry of Wordsworth, in order that we may see how the doctrine of the Logos still lives in modern thought. I do not of course suggest that Wordsworth owes anything to Stoicism: happily this is one of those fundamental truths which religion and poetry and philosophy are always rediscovering and reinterpreting in every age. To Wordsworth, as to the Stoics, Nature is a soul or spirit ${ }^{3}$, and divine:

"O Soul of Nature! that by laws divine

Sustained and governed, still dost overflow

With an impassioned life ${ }^{4}$ !"

1 The natura naturans of scholastic philosophy.

'See Zeno, Fr. 46, with Pearson's note.

${ }^{3}$ I do not mean to imply, of course, that Wordsworth's Nature is a $\pi \nu \epsilon \hat{v} \mu a$ in the full Stoic sense of the word. Pre-

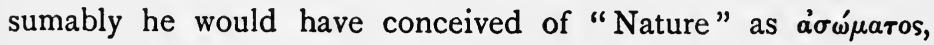
though (being a poet rather than a philosopher) he probably never reflected on the subject at all.

- Prelude, Book xiI. 
In more than one passage he represents Nature as an immanent indwelling soul, like the Stoic world-soul.

"To every form of being is assigned An active Principle

. . . . . it subsists

In all things, in all natures; in the stars

Of azure heaven ${ }^{1}$, the unenduring clouds,

In flower and tree, in every pebbly stone

That paves the brooks, the stationary rocks,

The moving waters and the invisible air.

Spirit that knows no insulated spot,

No charm, nor solitude; from link to link

It circulates, the Soul of all the worlds ${ }^{2}$."

And also in the well-known passages from Lines composed a few miles above Tintern Abbey and the description of the scenery of Switzerland, in the Prelude, Book vi ${ }^{3}$.

The central idea in these extracts is suggestive of the Stoic Logos; but in the last-mentioned passage there is one line- "the types and symbols of eternity" - that lifts us to a still higher level of idealism, recalling to the Platonist the world of invisible realities, whereof things seen and temporal

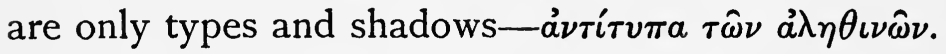
In the following passage of Browning's Paracelsus we have a splendid elaboration on the theme of the

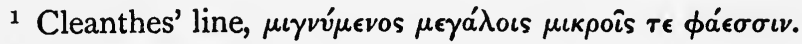

2 Excursion, Book IX.

${ }^{3}$ Quoted supra, The Divine Origin of the Soul, p. 48 ; Vitality of Platonism, p. 17. 
presence of God in Nature, without anything that exceeds the range of Stoic thought:

"The centre-fire heaves underneath the earth, And the earth changes like a human face; The molten ore bursts up among the rocks, Winds into the stone's heart, outbranches bright In hidden mines, spots barren river-beds, Crumbles into fine sand where sunbeams baskGod joys therein. The wroth sea's waves are edged With foam, white as the bitten lip of hate, When, in the solitary waste, strange groups Of young volcanos come up, cyclops-like, Staring together with their eyes on flameGod tastes a pleasure in their uncouth pride. Then all is still; earth is a wintry clod: But spring-wind, like a dancing psaltress, passes Over its breast to waken it, rare verdure Buds tenderly upon rough banks, between The withered tree-roots and the cracks of frost, Like a smile striving with a wrinkled face.

Above, birds fly in merry flocks, the lark Soars up and up, shivering for very joy; Afar the ocean sleeps; white fishing gulls Flit where the strand is purple with its tribe Of nested limpets; savage creatures seek Their loves in woods and plain-and God renews His ancient rapture. Thus $\mathrm{He}$ dwells in all, From life's minute beginnings, up at last

To man-the consummation of this scheme Of being, the completion of this sphere of life ${ }^{1}$."

One of the consequences that follow from the Stoic doctrine of the Logos is that man and Nature are bound in the closest possible sympathy and

\section{Paracelsus.}

A. E. 
union: "all things," says Marcus Aurelius, "are intertwined with one another in a holy bond...... for they all make up one world, and one God, one essence stretches through all"." No poet dwells more frequently or fondly on this topic than Wordsworth; and to him, as to the Stoics, the bond of union between nature and humanity is that the

"something far more deeply interfused,

Whose dwelling is the light of setting suns" dwells also in "the mind of man." And that is just the reason why in Wordsworth no one who is not a friend of man can hope to understand the voice of nature.

"But this we from the mountains learn And this the valleys show;

That never will they deign to hold

Communion where the heart is cold

To human weal and woe'."

It is " the still sad music of humanity that Nature sings,"

"Not harsh nor grating, though of ample power

To chasten and subdue."

Browning has more to say of man than of nature; but he too recognizes the affinity between them, and bases it, like Wordsworth, on the presence of the divine in both: as you will see if you read Henry Jones' book on Browning as a Religious and Philosophical Teacher.

It is time, however, to return to Cleanthes. We have seen that the Stoic doctrine of the Logos is not 
only an attempt to express the immanence of God in the world, but also represents the Godhead as the being who, in the words of Cudworth, reconciles "all the variety and contrariety of things in the universe into one most lovely and admirable harmony ${ }^{1 . "}$

"Nay, but thou knowest to make crooked straight,

Chaos to thee is order, hatred love:

Evil with good in one great harmony

Accordant, interfused through all the world

One universal, ever-living Word."

This conception also goes back to Heraclitus; it is indeed, as Alois Patin has pointed out, the Alpha and Omega of his whole philosophy. We are in the habit, and rightly, of associating with the name of Heraclitus the doctrine of the never-ceasing flux of things- $\pi a^{\prime} \nu \tau a \dot{\rho} \in \hat{\imath}$. The world, in his view, is one gigantic battle-field of opposing forces for ever waging internecine warfare. "Thou shouldest know," he says, "that war is universal""; "everything happens by strife" ${ }^{3}$ " " war is the father of all, and the king of all"." On this account he censures Homer for praying that strife might perish from among gods and men; for were there no strife, the universe would pass away ${ }^{5}$.

But Heraclitus' last word is not multiplicity and discord: it is unity and harmony. "Having hearkened not unto me, but to the Logos, it is wise to confess that all things are one." In a passage of

1 Intellectual System of the Universe, p. 207.
${ }^{2}$ Fr. 62.
3 Fr. 46.
${ }^{4}$ Fr. 44.
${ }^{5}$ Fr. $43 n$. 
Philo the Jew we read as follows: "That which is made up of both the opposites is one, and when this one is dissected, the opposites are brought to light. Is not this what the Greeks say their great and celebrated Heraclitus put in the forefront of his philosophy as its sum and substance, and boasted of as a new discovery ${ }^{1}$ ?" This then is the revelation of which Heraclitus believes himself to be the prophet. "The hidden harmony," he says, "is better than the visible"." It is just because men do not perceive this hidden harmony that they have gone astray. "They do not understand," he says, "how that which is discordant is concordant with itself : as with the bow and the lyre, so with the world: it is the tension of opposing forces that makes the structure one." "Were there no higher and lower notes in music, there could be no harmony at all." The fact that opposites are always passing into one another shows, according to Heraclitus, that they are only two different sides of the same thing. "The living and the dead, the sleeping and the waking, the young and the old, are the same: for the latter when they have changed are the former, and the former when they have changed again are the latter ${ }^{5}$." The gist of the whole matter is contained in the following fragment: "Join together that which is whole and that which is not whole, that which agrees and that which disagrees, the concordant and the discordant:

\footnotetext{
${ }^{1}$ Quoted by Patin, Heraklits Einheitslehre, p. 60.
8 Fr. 47.
${ }^{3}$ Fr. 45 .
- Fr. 43.
5 Fr. 78. 
from all comes one and from one comes all" ('ُא

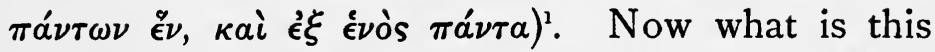
One which is at the same time Many, this Many which is at the same time One? What is the Unity in which all opposites are harmonised? Heraclitus himself gives the answer quite plainly in two fragments, one of which I have already quoted. "It is God who is day and night, winter and summer, war and peace, satiety and hunger"." And again: "To God all things are beautiful and good and right, but man believes that some things are wrong and others right $^{3}$."

If we try to estimate the ethical and religious value of this great idea, which appears again and again, I need hardly say, in nearly every form of pantheistic thought, and has also left its mark on Christian theism, we must distinguish, I think, between physical evil on the one hand, and moral evil on the other. The practical rule of Heraclitean as of Stoic ethics is that we should follow the universal, conform to the divine Logos: $\delta \epsilon \hat{\imath} \tilde{\epsilon} \pi \epsilon \sigma \theta a \iota$ $\tau \hat{\omega} \xi \nu \nu \hat{\omega}$. And inasmuch as the Logos is a harmony that inevitably involves what from our finite and partial point of view we call discord, it may be rightly said that we conform to the universal, when we recognize that pain and evil are necessary and inevitable concomitants of good in human life: a state of mind that induces patience and resignation. "They also serve who only stand and wait." "It is not good for men," says Heraclitus, "to get all that

$$
{ }^{1} \text { Fr. 59. }{ }^{2} \text { Fr. } 36 . \quad{ }^{3} \text { Fr. } 6 \text { r. }
$$


they desire. Sickness makes health pleasant and good, hunger satiety; weariness rest ${ }^{1}$." In the words of Robert Browning, a poet who frequently reminds us of Heraclitus,

"Type needs antitype:

As night needs day, as shine needs shade, so good Needs evil; how were pity understood Unless by pain?".

But there is something more to be said than this. Greek philosophy-the philosophy of Heraclitus, of Plato, of the Stoics-holds with not less emphasis than Christianity - that there is something of the infinite in every human being; and from this point of view pain and suffering may be regarded as a means of educating the more divine and universal part of our nature. Suffering is in fact a $\gamma v \mu \nu a ́ \sigma \iota \nu$ or school in which we should learn to look at our individual lives from the higher standpoint, the standpoint of the infinite or whole; for "to God all things are beautiful and good and right," though men think otherwise. God, says Plato, created the part for the sake of the whole, and not the whole for the sake of the part ${ }^{3}$, an echo, it would almost seem, of the sentiment attributed to Heraclitus, that "God accomplishes all things with a view to the harmony of the whole." It is a fundamental article of the Stoic creed that nothing can befall the individualnot sorrow, nor pain, nor death-which is not for the good of the whole. We must therefore study to
1 Fr. 104.
2 Francis Furini.
3 Laws, $903 \mathrm{C}$.
4 Fr. 6r. 
live in the universal, and not in the part, to embrace in our regard, as Marcus Aurelius expresses it, "all time and all being, and see that by the side of being, all individual things are but a grain of millet, by that of time as the turn of a screw ${ }^{1}$." Later Stoicism, in particular, is permeated by this idea. The ideal man, says Marcus Aurelius, is "convinced that destiny is good; for his apportioned destiny sweeps man on with the vaster sweep of things ${ }^{2}$."

$\mathrm{He}$ "welcomes gladly all that in the web of destiny befalls him ${ }^{3}$." "I am in harmony with all that is a part of thy harmony, great Universe. For me nothing is early and nothing late, that is in season for thee. All is fruit for me, which thy Seasons bear, O Nature! From thee, in thee, and

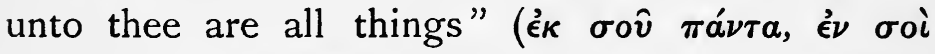

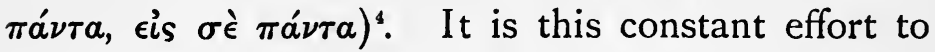
rise above the narrow individual standpoint and survey our individual life as part of the universal order-sub specie aeternitatis as it were-that lends to Stoicism its peculiar moral dignity and elevation: but we must beware of supposing that from the Stoic point of view our essential individuality would be obliterated or enslaved by the realisation of such an ideal. On the contrary, the true self would be emancipated-emancipated from the tyranny of the lower and unessential self, which is perpetually striving, by the gratification of the sensual and selfish impulses, to break loose from the whole

${ }^{1}$ x. I 7 , tr. Rendall.

${ }^{3}$ Ibid.
2 III. 4, tr. Rendall.

4 IV. 23, tr. Rendall. 
of which we are a part and become no more than "a dismembered hand, or foot, or decapitated head, lying severed from the body to which it belonged ${ }^{1}$." It is only in the service of the divine and universal law of virtue, according to the Stoics, that man attains his true individuality, his essential freedom: for what does freedom mean? Freedom to do what is right. This is the meaning of the Stoic paradox that only the wise man is free. Epictetus puts the whole matter in a nutshell, when he says "Freedom is a name for virtue, slavery a name for vice." You will see that the Stoic conception of moral freedom is like the Christian, with the difference, of course, that the Logos whereby the Christian becomes free is the son of Man. "If the son shall make you free, ye shall be free indeed"." "For he that was called in the Lord, being a bondservant, is the Lord's freedman : likewise he that was called, being free, is Christ's bondservant "." In St Paul he alone is free who is the $\delta \circ \hat{v} \lambda o s \mathrm{X} \rho \iota \tau \tau o \hat{v}$. Anyone who attempts to express the philosophical meaning of this article of Christian faith must inevitably do so in terms of Stoicism, as may be seen from the following extract from Principal Caird's Fundamental Ideas of Christianity: "It is the freedom and fulfilment of our spiritual being to breathe in the atmosphere of the universal life, to become the organ of the infinite reason. And the goal and perfection of our spiritual life would be reached, if

${ }^{1}$ M. Aur. viII. 34, tr. Rendall.

2 Fr. 8.

${ }^{3}$ St John viii. 36.

4 I Cor. vii. 22. 
every movement of our mind, every pulsation of our intellectual and moral life were identified with it, so that in isolation from it we had no life we could call our own ${ }^{1}$." There is nothing in this sentence that a Stoic might not have written. And to the Stoic not less than to the Christian, as I have already indicated, the road to spiritual freedom may sometimes be the via dolorosa.

"By many a stern and fiery blast

The world's rude furnace must thy blood refine,

And many a gale of keenest woe be passed,

Till every pulse beat true to airs divine ${ }^{2}$."

I stated above that, in endeavouring to estimate the value of the Stoic conception of the Logos as the unity in which all opposites are harmonised, it is important to draw a distinction between the evils which we call physical and those which we call moral. So far as physical evil is concerned, the solution which the Stoics offer, that pain and suffering are part of the divine dispensation and contribute to the universal harmony, though not perhaps entirely satisfactory to the intellect, is one that in nearly every age has powerfully appealed to the religious sentiment ${ }^{3}$. But when we proceed, as the Stoics sometimes do, to apply the same

1 Vol. I., p. 153.

2 Keble. Palgrave's Treasury of Sacred Song, p. 2 I 5.

3 There are, however, not a few traces of other solutions in Stoicism pointing to a kind of qualified dualism. We hear, for

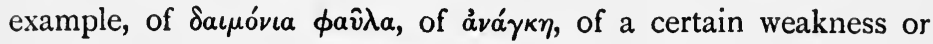

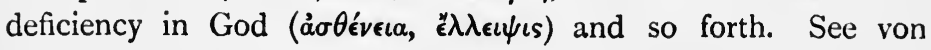
Arnim, l.c. II. I I 7 I, I I 74, I I 78, I 183 al. 
solution to the existence of moral evil, neither the intellectual nor the religious part of our nature is likely to acquiesce. It is of little avail to assure us that moral evil fulfils a useful part in the economy of the whole: for without it there would be no such thing as moral good. Continence, for example, has a meaning only in relation to incontinence, justice to injustice, truth to falsehood and so on. These and other such considerations were frequently brought forward by Chrysippus, who takes refuge, as usual, in a similitude. "Just as in comedies," he says, "there are some ludicrous jests, which regarded in themselves are bad, but which nevertheless add a certain charm to the poem considered as a whole, so if you consider wickedness alone and by itself, it is deserving of censure: but wickedness is not without its use in the whole." To which Marcus Aurelius very properly replies: "Take care that you do not become the cheap coarse jest of which Chrysippus speaks"." The question as to the origin and place of moral evil in the universe is of course one of the greatest difficulties in every pantheistic or monistic system, and it is interesting to notice that the solution attempted by Chrysippus appears continually in the history of pantheism. We may take Spinoza as an example. "Man," according to Spinoza-I quote from Mr Picton's Pantheism ${ }^{3}$ " is in God, and of God. But what are we to say of bad men, the vile, the base, the liar, the murderer? Are they also in God and of God? Spinoza

1 von Arnim, II. I 18 I.

${ }^{2}$ See vi. 42.

3 p. 69. 
does not blench. Yes, they are. But here comes in his doctrine of 'adequate' and 'inadequate ideas.' Thus, if you see the colour red, it completely expresses itself. It cannot be defined and needs no explanation. As it is in the Infinite Thought so it is in ours. We have an 'adequate idea' of it. But now if you see on an artist's canvass a splotch of red and blue and yellow, part of a work only begun, it gives you no adequate idea. True, you have an adequate idea of each several colour, but not of their relations to the work conceived. To get that you would have to enter into the mind of the artist and see as he sees. Then the splotch of colour would take its place as part of a harmonious whole; and would give you an adequate idea just as it does to the artist." In this way, according to Spinoza, we must presume that if we could see things with the eye of Infinite Thought we should have an "adequate idea" as he calls it, that is to say, we should fully comprehend how moral evil promotes the universal harmony which he identifies with God.

Such a solution, while it shelves the intellectual difficulty by administering as it were a sedative to the enquiring mind, leaves our moral sense unsatisfied. We feel that virtue and vice are essentially antagonistic and irreconcilable: so that it is no real monism which looks on the Deity as the unification or harmony of the two, but only dualism in disguise, dualism masquerading under the mask of monism. Hence the Stoics felt themselves compelled upon 
occasion to cast about for a different solution. It is, of course, a favourite device of pantheism to cut the knot by denying the reality of moral evil altogether: evil is the negative of good, a "phantom that dissolves before the light." The Stoics, however, could not possibly take refuge in a view so entirely alien to the high moral earnestness which distinguishes their creed. Between virtue and vice, in Stoicism, the gulf is infinite: according to the strictest teaching of the school, indeed, moral good and moral evil are the only things that really count: all other things, riches and poverty, sickness and health, even life itself, are "indifferent." The solution which the Stoics tended to adopt is contained in the words of Cleanthes: God is the author of all things, "except what wicked men do through their own folly." It is simply the popular doctrine of free-will and moral responsibility, the doctrine on which the institutions of civilised society are founded, praise and blame, reward and punishment, and so forth. In its theoretical expression it is as old as Homer, who in the Odyssey makes Zeus exclaim: "Men say that their evils are from us, but they themselves through their own infatuation, have sorrows beyond that which is ordained ${ }^{1}$." These words were constantly in the mouth of Stoic teachers ${ }^{2}$, and Cleanthes is probably thinking of them here. The theory which they embody is doubtless of considerable practical value, but it is

1 Od. 1. 32-34.

2 See the passages in von Arnim, II. 999 f. 
hardly consonant with theoretical monism; and it comes into direct and immediate conflict with the Stoic belief in predestination. If every effect, as the Stoics believed, is the result of an unalterable chain of causes, it is difficult to see how either the sinner or the saint can possibly be other than he is. This obvious and patent contradiction did not escape the notice of ancient critics of Stoicism; and desperate attempts were made to evade it. Those of you who are curious on this subject will find all the most important materials for studying the matter in von Arnim's Stoicorum veterum fragmenta $^{1}$. I will content myself with saying that although in the course of their discussions on the subject they succeeded in bringing to light some precepts of the highest ethical value, and anticipated nearly all the principal attempts of later philosophy to deal with the problem of free-will and predestination on its speculative side, they were unable to invent a satisfactory intellectual solution of a problem which philosophy, perhaps, will never solve. But to any one who pleaded predestination as an excuse for wrong-doing, the Stoic had his answer ready: if the sin was fore-ordained, so also was the punishment. We are told that Zeno was once whipping a slave for theft, and the slave-who may perhaps have overheard one of his master's disputations-protested: "It was fated for me to steal." "Yes, and to be whipped," said Zeno ${ }^{2}$. This is the Stoic counterpart of the old Aeschylean doctrine

1 II. $974 \mathrm{ff}$.

${ }^{2}$ Apophthegmata of Zeno, 54, Pearson. 
that even if the responsibility rests with Fate, it is still the doer who must suffer. It is in vain that Clytemnestra, as she shrinks from the avenging sword, exclaims :

"Not I, but Fate, is guilty of these sins."

The reply of Orestes leaves no loophole of escape:

"This fatal doom then, it is Fate that sends"."

We have now considered the principal ideas contained in the second of the four divisions into which we have divided the hymn of Cleanthes. The two remaining sections will not detain us long. Cleanthes proceeds to describe how the wicked turn aside from the universal law, each pursuing his own individual good, and missing it, just because he does not seek it in the universal; after which he prays for their illumination.

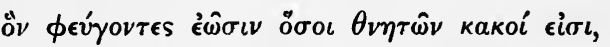

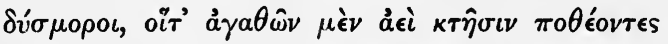

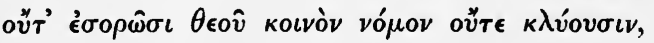

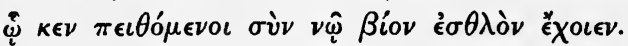

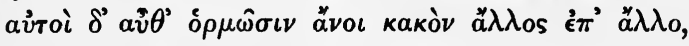

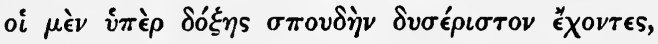

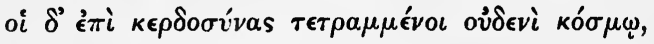

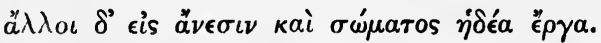

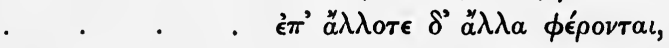

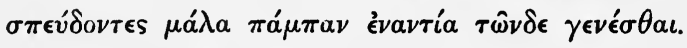

"One Word-whose voice alas! the wicked spurn; Insatiate for the good their spirits yearn: Yet seeing see not, neither hearing hear God's universal law, which those revere, 
By reason guided, happiness who win.

The rest, unreasoning, diverse shapes of sin

Self-prompted follow: for an idle name

Vainly they wrestle in the lists of fame:

Others inordinately riches woo,

Or dissolute, the joys of flesh pursue.

Now here, now there they wander, fruitless still,

For ever seeking good and finding ill."

Here again there are reminiscences of Heraclitus. In one fragment, for example, we read: "The Logos is universal: but most men live as if they had a private intelligence of their own ${ }^{1}$; and in another : "They are at variance with that with which they live in most continual intercourse ${ }^{2}$." The general idea in this part of the hymn, if we read it in connexion with what precedes, is, as I have said already, that man alone is oblivious of his Maker: the rest of Nature, both inanimate and animate, obeys the law of God. For a Christian parallel we may perhaps compare the beautiful lines of Henry Vaughan from the poem entitled Creation waiting for Revelation.

The prayer with which the hymn concludes begins with supplication, and ends in praise:

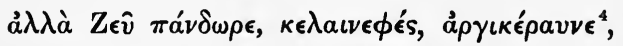

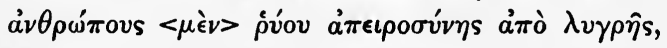

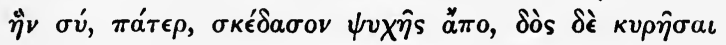

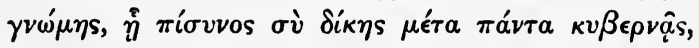

1 Fr. 92.

2 Fr. 93.

${ }^{3}$ Quoted supra, p. $148 \mathrm{f}$.

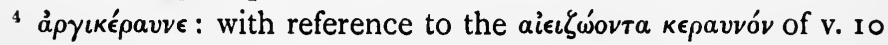
(see supra, p. I $5^{1}$ ). 


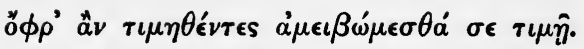

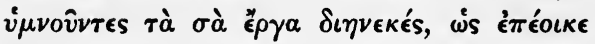

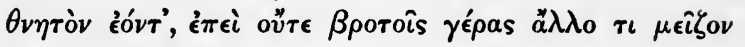

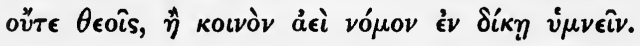

"Zeus the all-bountiful, whom darkness shrouds, Whose lightning lightens in the thunder-clouds; Thy children save from error's deadly sway: Turn thou the darkness from their souls away: Vouchsafe that unto knowledge they attain; For thou by knowledge art made strong to reign O'er all, and all things rulest righteously. So by thee honoured, we will honour thee, Praising thy works continually with songs, As mortals should; nor higher meed belongs E'en to the gods, than justly to adore The universal law for evermore."

Side by side with these lines I will ask you to set two characteristic utterances of later Stoicism, one by Epictetus the slave, and one by his pupil Marcus Aurelius, the Emperor of Rome. The first is as follows: "I am a lame old man, and can do nothing else, but I can sing praise to God. If I were a nightingale, I should do the part of a nightingale, if a swan, I should act like a swan. As it is, I am a rational being: I must sing praise to God. This is my work: I do it, and will not desert my post, so long as I am permitted to remain; and I call upon you to join in this same song." These are the words of the slave: hear now the words of the Emperor. "What then? Serenely you await the end, whether it be annihilation or change. And while 
the hour yet tarries, what sufficeth? Reverence and bless the gods, do good to men, endure and

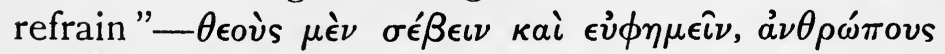

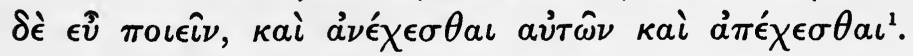

The object of these lectures, as I said at the beginning, has been to explain and illustrate the religious ideas of Stoicism. But there is another side from which the religion of Stoicism may be studied. Read the history of the early Roman Empire, and you will begin to realise the practical effect of these ideas in ennobling the lives of men and women, and keeping them faithful unto death. There are few more heroic figures in history than the Stoic martyrs of the time of Nero. The dying words of Arria, as she took the dagger from her breast and gave it to her husband, "Paete, non dolet," "Paetus, it does not hurt" -were not as lesser natures have sometimes insinuated, a histrionic exclamation: no one who realises what death means will for a moment cherish such an unworthy thought: they were the spontaneous utterance of a noble taught by Stoicism to triumph over pain and death. And Arria is typical of many of the noblest and gentlest spirits in the dark days of the Reign of Terror. But on the mass of the people Stoicism, it must be confessed, made but little impression. Many reasons might be alleged in explanation. Contrasting Christ with Socrates, Justin Martyr says :

1 v. 33 , after Rendall.

2 Pliny, Ep. III. 16.

A. E. 
"In Christ-who was known in part by Socrates (for Christ was and is the Logos present in every man...) in Christ not philosophers alone and scholars believed, but also working men, the ignorant as well as the learned, and were taught by Him to despise glory and fear and death ${ }^{1}$ " To much the same effect Origen ${ }^{2}$ says that Plato and the wise men of the Greeks catered only for those who are considered the better classes, and despised the masses: whereas the Jewish prophets and the disciples of Jesus try to provide the most wholesome spiritual food for the masses of mankind.

Greek philosophy was far more in touch with ordinary uneducated human nature than modern philosophy is; but even Greek philosophy was never "popular." Plato in one passage says pathetically: "I do not expect that the majority of men will ever believe in the theory of Ideas ": and in another passage we have the significant words $\tau$ oîs $\delta \dot{\epsilon} \pi o \lambda \lambda$ oís

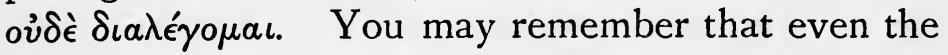
more liberally-minded among the early Christian fathers sometimes asked the question, "Did philosophy ever make the ordinary man live better?" But there are two reasons in particular why Stoicism failed to become a religion for the mass of mankind; and to these I will now draw your attention, both on other grounds, and also because, amid much Stoicism that resembles Christianity, they bring vividly before us some of the great and fundamental differences between Stoic philosophy and the Christian faith.
1 Apol. 461 A, в, Migne.
${ }^{2}$ Against Celsus, 5 $^{\circ} 5$ c ff., Migne. 
In the first place, the belief in immortality, which some writers have held to be essential to any religion that is to secure the adhesion of ordinary men, plays little or no part in Stoicism. It is true that, according to Cleanthes, all human souls survive till the universal conflagration that separates one aeon from another; but the Stoics were not unanimous on this point, and Chrysippus for his part believed only in a kind of conditional immortality: the souls of the good, he thought, endure till the conflagration, but those of the wicked perish sooner. Chrysippus appears to have made some attempt to differentiate between the condition of the wicked and the condition of the good after death ${ }^{1}$; but in general we may say that the notion of a future life had no practical significance in earlier Stoicism. At a later period, when the austerity of Stoic teaching began to be tempered by Platonism, considerable stress was sometimes laid on the doctrine of purgatory and a place of reward hereafter. We have an illustration of this tendency in the sixth book of.Virgil's Aeneid ${ }^{2}$, and still more in Seneca, who in his eschatology owes much to Plato. But the question of immortality was to the last an open one in Stoicism. Marcus Aurelius, for example, reserves his assent : death is either extinction or transmutation: and Epictetus would seem to have definitely disbelieved in the continuance of individuality beyond the grave. "Shall I then no longer exist? You will not exist, but you will be something else, of which the world

${ }^{1}$ See von Arnim, l.c. II. 8I 2-8I 4 . 
now has need; for you also came into existence not when you chose, but when the world had need of you'."

The truth is that from the lofty standpoint of Stoicism the question of immortality is irrelevant or worse: virtue must be pursued for its own sake : it would cease to be virtue if inspired in any measure, however slight, by the hope of future bliss or the fear of future misery. We need not enquire whether Stoicism was right or wrong in such a view: all I wish to point out is that Stoicism offered no real satisfaction to the craving of the human heart for immortality, and for this reason, among others, could never become the universal religion of which its noblest prophets dreamed. Life and immortality had yet to be brought to light through the Gospel.

And this leads us to the second of the two great reasons why Stoicism failed to penetrate the hearts and consciences of ordinary human beings. It lacks above all things the motive principle of personality.

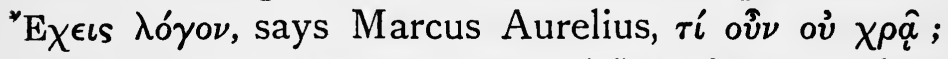

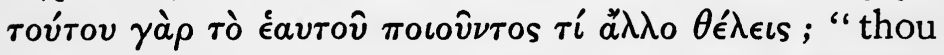
hast reason, why then not use it? If reason does its work, what else dost thou require ${ }^{2}$ ?" We might imagine a Christian subject of the Emperor replying, "Yes, but we need some driving power to make the Logos in us do its work ${ }^{3}$. And this we find in Christ, the incarnation of the Logos, the God-man,

1 3. 24 , tr. Long.

2 IV. I3.

${ }^{3}$ Cf. Lactantius, Divin. Inst. III. 27, "Sed nihil ponderis habent illa praecepta, quia sunt humana," etc. 
with whom we die to sin that we may rise to the life of virtue and holiness." In other words, it is the doctrine of the incarnate Logos that constitutes the fundamental difference between Christianity and Stoicism. I have already said that the early Christian fathers spoke of Greek philosophy as a "preparation" for the Gospel. In the spirit of this remark, let us enquire, in conclusion, whether there is anything in Greek philosophy that can fairly be considered to pave the way for the words near the beginning of the fourth Gospel: " the Logos became flesh, and dwelt among us"?

The tendency of Greek philosophers to personify

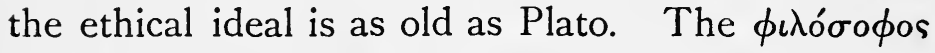
or lover of wisdom, whose ideal portrait he paints for us in the Republic ${ }^{1}$ and the Theaetetus ${ }^{2}$, is Plato's conception of the perfect man; and we have already seen that the human in Plato, understood in its truest meaning, is also the divine. In each of these pictures, Plato has in view his master Socrates, not as he was in life, but idealised; for Socrates no sooner died than he became to his followers an idea, an inspiration, an ever-living example of how the righteous man should live and die. The same tendency is at work in Aristotle's description of the $\mu \epsilon \gamma a \lambda{ }^{\prime} \psi v \chi \chi^{\circ}$ or high-minded man, the embodiment of every virtue, as Aristotle understood the word; a kind of $\theta \epsilon \dot{o}^{\prime} \dot{\epsilon} \nu$ à $\theta \rho \dot{\omega} \pi$ oเs and entitled to the same kind of reverence and honour as the gods. In post-Aristotelian philosophy the personification of the moral standard

$$
{ }^{1} 475 \text { в ff., } 485 \text { A ff. } \quad{ }^{2} 7_{2} \text { D ff. }
$$


appears in the doctrine of the Wise Man, a doctrine the true significance of which is seldom understood, because superficial observers in antiquity, genial men of the world like Horace, or professional scoffers like Lucian, are always turning it into ridicule, and modern writers only too often follow in their wake. The Wise Man of Stoicism and Epicureanism is simply an attempt to give a kind of quasi-visible form and substance to their conception of the ultimate good.

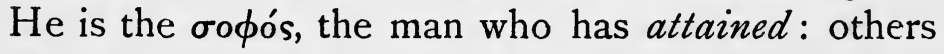

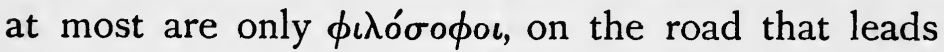
to attainment. But, apart altogether from the ethical divergence of the two schools, there is a profound and essential contrast between them on the question whether the Perfect Man has ever actually appeared on earth. The Epicureans thought he had, and identified him with Epicurus. They even went further, and after their master's death, if they did not actually deify him, they nevertheless spoke of him as a God, and found in a kind of positivist worship of Epicurus a certain satisfaction for those religious instincts, which neither the gods of Greece nor the phantoms of the Epicurean intermundia could awaken or appease. It is more than a mere metaphor when Lucretius exclaims : "a God was he, a God, who first discussed the way of life which now is called wisdom, and who by his skill rescued human life from such great waves and darkness and set it in so calm a haven and in a light so clear." The Stoics took a different, and, in reality, perhaps 
a truer view. The Good Man, in Stoicism, was always an ideal : neither Socrates nor Zeno, nor any other of them whom they sometimes named as types, was allowed to be more than an approximation. "Ubi enim istum (sapientem) invenies, quem tot saeculis quaerimus?" "Where will you find the Wise Man we are looking for throughout the ages $^{1}$ ?" And in Epictetus we read: "Let any of you show me a human soul ready to think as God does, and not to blame either God or man, ready not to be disappointed about anything, not to consider himself damaged by anything, not to be angry, not to be envious, not to be jealous; and why should I not say it direct? desirous from a man to become a God, and in this poor mortal body thinking of his fellowship with Zeus. Show me the man. But you cannot ${ }^{2}$." Now I will ask you to dismiss from your minds for a moment the gibes of Horace, and remembering only the one essential doctrine of Stoic anthropology, that is, the unity of man's spirit with the spirit of God, to consider what the Stoic ideal of the perfect man must necessarily be. He must needs be one whose soul is attuned to perfect and unbroken harmony with him "in whom we live and move and have our being," one who, in the words of Epictetus, always "thinks as God does," and is the embodiment of perfect manhood just because in him "dwells all the fulness of the Godhead bodily"; for in Stoicism, as we have seen, man is most manlike when most like to God. The perfect man, said the

1 Seneca, De Tranquillitate Animi, 7. 4.

211. 19. 
Stoics, is divine, because God dwells in him : Acious

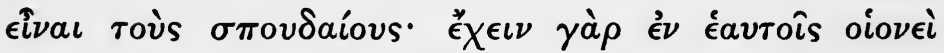
$\theta \epsilon{ }^{\prime} \nu^{1}$.

It is from this point of view that the personification of the ethical ideal, as expressed in the Stoic doctrine of the $\sigma o \phi o ̀ s$ or $\sigma \pi$ ovdaios, appears in the light of a "preparation" for the Christian identification of the Logos with Jesus Christ. To the pathetic cry of Seneca, "ubi istum invenies quem tot saeculis quaerimus?" "where will you find him we look for through the ages?" the author of

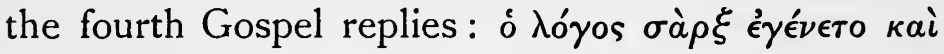

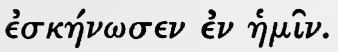

The Stoic doctrine of the Logos as God immanent in Nature and in man, was inherited by Philo, who under Platonic and possibly also Jewish influence distinguishes between the Logos and the supreme God, and so replaces pantheism by theism. At the same time he frequently describes the Logos in terms which, as $\mathrm{Mr}$ Purves remarks, "often bear striking resemblance to New Testament descriptions of Christ"." To quote a few among many such characterisations, the Logos, in Philo, is the Divine Word, the first-born son of God, the image of God, God's vice-gerent in the world, his prophet and interpreter, the high-priest who intercedes with God for the whole world, the intermediary between God and Man, himself neither God nor man, but partaking of the nature of both. Then came the great and de-

1 Diog. Laert. vil. I 19.

2 Hastings, Dictionary of the Bible, s.v. Logos. 
cisive step, for which, as I have tried to show you the teaching of post-Aristotelian philosophy, or rather of the whole of Greek philosophy from Plato onward, had prepared the way, by its ever-growing tendency to personify the ethical ideal. The link between Greek philosophy and Christianity was once for all established when St John proclaimed that the Logos had become incarnate in the founder of our faith. It has been truly said that "the doctrine of the Logos in the post-Apostolic age was the natural meetingpoint of Christianity with the best elements in the old religions. It seemed to many to furnish proofs that the new religion was in reality the full expression of truths taught by philosophy." In his Christian Mysticism, Dr Inge, on the strength of a passage of Aurelius quoted in Eusebius, hazards the suggestion that "the Apostle, writing at Ephesus, refers deliberately in his prologue to the doctrine of the great Ephesian idealist ${ }^{2}$ " Heraclitus, from whom, as we have seen, the doctrine in question is ultimately derived. We can never be sure of this: but without touching on the disputed question as to the immediate sources of the Johannine Logos, we may say with confidence that no one can read the first five verses of St John's Gospel in the light of the great ideas I have placed before you without acquiring a new and deeper apprehension of the mean-

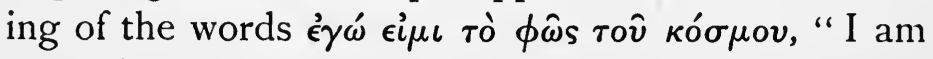
the light of the world." "In the beginning was the Word...In him was life; and the life was the light

$$
{ }^{2} \text { Purves, l.c. }{ }^{2} \text { p. } 47 \mathrm{n} \text {. }
$$


of men. That was the true light, which lighteth every man"-that is, I believe, every man, in every age and country, both before and after the incarnation of the Word-" that cometh into the world"." Before the birth of Christ men spoke of Jew and Gentile, barbarian and Greek. The "Light of the World" has risen, and, well -we have changed our formula: we speak of Christian and heathen, Christian and pagan. If ever we fully understand the message entrusted to St John, we shall rather say, with Justin Martyr: "They that lived in company

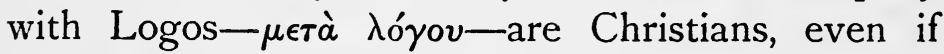
they were accounted atheists. And such among the Greeks, were Socrates and Heraclitus ${ }^{2}$." It has often seemed to me that this famous sentence, which is sometimes treated as embodying an uncritical and merely sentimental opinion, indicates the road which Christian theology will in future follow, nay is even now, I think, beginning to follow. The comparative study of religion, which has never been so ardently pursued as in the present day, is revealing more and more the essential unity amid diversity of all religion. We are gradually apprehending the truth which the poet expresses in the words :

"Children of Men! the unseen Power, whose age

For ever doth accompany mankind,

Hath looked on no religion scornfully,

That men did ever find.

${ }^{1}$ The Authorised Version seems to me right here as against the Revised.

${ }^{2}$ Apol. 397 c, Migne. 
Which has not taught weak wills how much they can?

Which has not fallen on the dry heart like rain?

Which has not cried to sunk, self-weary man,

Thou must be born again ${ }^{1}$ !"

I do not think it can be denied that the general tendency of thought is now in the direction of making the Christian religion prima inter pares, rather than sui generis. "It is not the interest of the apologist for Christianity," says one of the wisest of recent divines, "to sever it from all connexion with the religious thought and culture of the pre-Christian ages." "The argument" (for the divine origin of Christianity) "does not suffer, but only gains fresh force, if it can be shewn that the highest thought and life... of all the races and nations of the ancient world constituted a preparation for it, that the whole order of human history in the pre-Christian ages pointed to Christ, and that he was, in this sense, 'the desire of all nations'."' And if ever this tendency becomes predominant among Christian thinkers, the Johannine interpretation of the Logos-doctrine-the Johannine philosophy of religion, for such, in effect, it is-will furnish the Christian with a point of view from which religion and Christianity, Christianity and religion will still be seen to be the same-and in a deeper sense, perhaps, than ever.

If we look upon Christ as the pre-existent, universal and eternal Logos, in accordance with the

1 M. Arnold, Progress. Cf. Justin Martyr, 396 A, Migne $\pi \alpha \rho \grave{\alpha}$

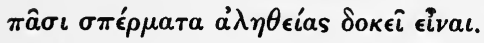

2 J. Caird, Philosophy of Religion, p. 335. 
teaching of St John and Justin Martyr, it becomes

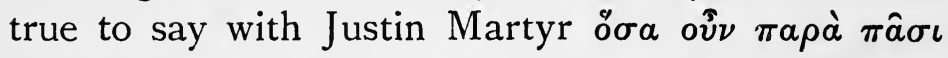

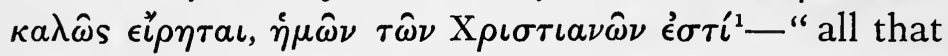
has been well and truly said by thinkers in any age, is part of Christianity." Perhaps it is in this way that history will one day justify-nay, is already justifying - the claim of Christianity to be in the profoundest meaning of the word a universal religion. We shall learn at last to recognise that it is the same God-ó aútòs $\theta \epsilon$ cós $^{2}$-whom all men worship under diverse names- $-\pi \circ \lambda \boldsymbol{\nu} \omega \dot{\nu} \boldsymbol{\mu} \mu \mathrm{os}$, as Cleanthes says. We shall understand that it is really a picture of the Christian religion which Clement sets before us in a noble passage of his Miscellanies" : The Father and Maker of all things is apprehended by all things through an innate faculty ('́) $\mu \dot{v} \tau \omega s)$ and without teaching, things inanimate sympathizing with the living creation. Of those who are alive, some are already immortal, working in the light of day $\left(\kappa a \theta^{\prime}\right.$

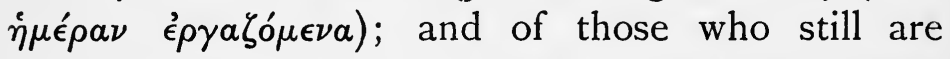
mortal, some are in fear, being carried still within their mother's womb; while others are guided by free and independent reason ( $a \dot{\tau} \tau \epsilon \xi o v \sigma i \omega \lambda o \gamma \iota \sigma \mu \hat{\omega})$. We divide mankind into barbarians and Greeks; but no race anywhere, either of tillers of the soil, or nomads, or those who dwell in cities, can live without an inherent faith in something higher than themselves. Wherefore every nation of the East, and every nation that touches the Western shores,

${ }^{1}$ Apol. 465 c, Migne. $\quad{ }^{2}$ Clem. Strom. vi. 5. 26I B, Migne.

3 Strom. v. 196 в ff. 
the nations of the North and all who dwell towards the South, have one and the same innate conception ( $\left.\pi \rho{ }^{\prime} \lambda \eta \psi \iota \nu\right)$ of Him who has established the Kingdom; for the most universal of his operations extend equally through all." It is for this sublime, and as it appears to me truly Christian, conception that the hymn of Cleanthes prepares the way: and that is my justification for having asked an assembly of Christian teachers to consider for a little what it means.

Books recommended in connexion with these lectures:

Pearson, Fragments of Zeno and Cleanthes, London, I89I.

Von Arnim, Stoicorum veterum fragmenta, Leipzig, 1905.

Epictetus, translated by Long, London, 1887 .

Marcus Aurelius, translated by Rendall, London, 1898.

E. Caird, The Evolution of Theology in the Greek Philosophers

(Chapters on Stoicism), Glasgow, 1904.

J. Caird, The Fundamental Ideas of Christianity, Glasgow, 1899.

Höffding, The Philosophy of Religion, tr. Meyer, London, I 906.

J. Caird, The Philosophy of Religion, London, 1904. 


\section{ANCIENT GREEK VIEWS OF SUFFERING AND EVIL.}

Many of the Christian fathers-Justin Martyr, for example, and more especially Clement of Alexandria-were in the habit of describing Greek Philosophy as the preparation or propaedeutic-

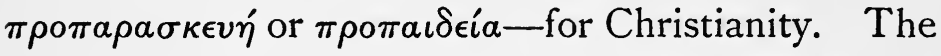
great conception which runs through the writings of Clement in particular is that of a gradual education of the human race, culminating in the Christian revelation, when the dóyos or Word, which Greek thinkers had dimly apprehended by the light of reason, became flesh, and dwelt among men: $\delta$

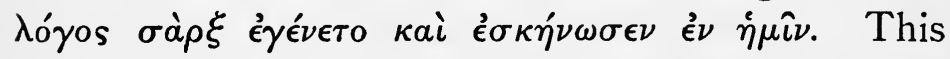
is not the place in which to discuss whether such an interpretation of Greek thought is adequate or not $^{1}$, or whether it is really true that the Christian revelation is the crown and consummation of all religious development, and solves once and for ever the difficulties that perplexed Greek thinkers. The question whether Christianity provides a final and satisfactory intellectual solution of the mystery of existence will certainly force itself upon your minds, in the course of your enquiries into the

1 For such a discussion see supra, pp. $184 \mathrm{ff}$. 
Christian conception of suffering and its place in the divine economy. But this much, at least, I think we may safely affirm. A short examination of ancient Greek ideas about suffering and evil will form a suitable propaedeutic or introduction to the particular course of study which you are about to undertake; for it is the characteristic merit of Greek literature that it raises nearly all the really fundamental questions which later moral and religious philosophy has endeavoured to answer, and at the same time offers in a comparatively simple and intelligible form, many of the solutions at which subsequent thinkers have independently arrived. Lucidity is one of the special virtues of Greek writers. They understood what they wished to say, and said it with precision.

Nowhere, perhaps, does one find a deeper or more all-pervading consciousness of the presence of evil in the world than among the Greeks. The usual view of the perpetual gaiety of the Greeks, as exemplified by the remark of the Egyptian priest

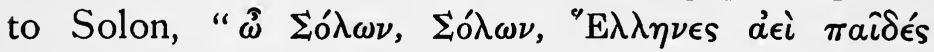

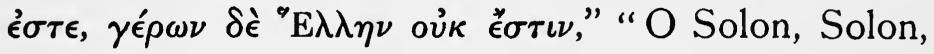
you Greeks are always children, and there is not a Greek that is old," needs modification. The Greeks were not always children, in the sense of showing continually the gaiety and light-heartedness of little children.

A multitude of passages in Greek literature might be quoted by way of illustration; but it will suffice to remind you of the proverbial saying, 
traceable in the last resort to Homer, to the effect that the immortals have dispensed to mortal men two evils for one good ${ }^{1}$. Pindar, Euripides, and many other authors are apt to dwell on the sadness of man's lot, and even Plato, who is optimistic as a rule, thinks that the evils in life far outnumber the good things. Not that Greek literature as a whole can fairly be called pessimistic. On the contrary, though pessimism predominates in Euripides, perhaps, one of its most characteristic notes is that of effort, aspiration, ceaseless struggle against adversity. It is just because the odds against him are so great that man has the opportunity to be a hero: that is a leading thought in Homer, Pindar, Sophocles and other Greek authors. The certainty of death becomes itself an inspiration to noble endeavour. "Forasmuch as we must die," cries Pindar, "why should one sit idly in the dark, nursing an old age unknown to fame, without part or lot in noble deeds" ?" "Work, for the night cometh," is a constant theme in Greek literature. But, at the same time, a profound strain of melancholy makes itself heard in nearly all the reflective passages of Greek writers; and frequently the view is expressed that the happiest lot is not to be born, and the next happiest, having once been born, to pass the gates of Hades as soon as possible. Solon is one of the most optimistic of Greek writers, but even he says "No one is happy, but all on whom the sun looks down are miserable." Hence the
1. $11.24 .527 \mathrm{ff}$.
2 Ol. $1.82 \mathrm{ff}$.
3 Fr. 14. 
significance of the saying "Call no man happy till he dies." Death is often represented as the only physician of life's ills.

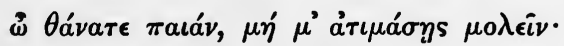

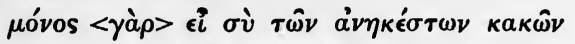

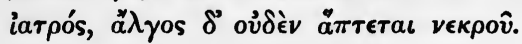

"O healing Death! say me not nay, but come!

Sole cure art thou of woes incurable;

Sorrow lays not her hands upon the dead ${ }^{1}$."

What different explanations, then, do the Greeks suggest of the evil in human life? That is the question which in this lecture I will ask you to consider.

I. At first, before men began seriously to reflect on moral difficulties, the tendency was to ascribe evil as well as good directly to the gods. Zeus, in

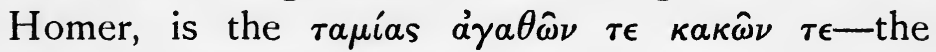
steward of things evil and things good: in Pindar,

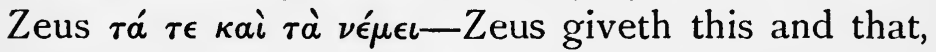
meaning good and evil. This is the ordinary, conventional, unreflective view, and as such appears in the bulk of non-philosophical Greek literature, sometimes, as in the tragic poets, side by side with more refined suggestions, of which I will speak presently. We must remember, of course, that the Homeric Zeus is a morally composite being-part evil and part good-benevolence and malevolence combined in a single personality, a blend of naturalism and

${ }^{1}$ Aesch. Fr. 255, Nauck. See further on this subject, Butcher, Some Aspects of the Greek Genius: Essay on the Melancholy of the Greeks.

A. E. 
idealism: so that it is natural enough for evil as well as good to be ascribed to him. But for the most part, when the Greeks attributed their misfortunes as well as their prosperity to the Gods, the moral dualism of the Godhead was not consciously present to their minds: all they meant was that everything we have, evil and good alike, is given us by the almighty powers on whom we depend in all the relations of life. The Gods, being as they are in Homer the sole and universal causes, are necessarily the cause of evil rather than of good. In the Homeric religion there is no devil to bear the blame. So much then for the first and simplest view, that evil as well as good comes from the Gods.

2. Against this view that evil comes from the Gods we find a dramatic protest, as early as the time of Homer himself. "Do you know," cries Zeus, revolving in his mind the fate of Aegisthus, "how vainly do mortal men blame the Gods! For of us they say comes evil, whereas they even of themselves through their own infatuation ( $\sigma \phi \hat{\eta} \sigma \iota \nu$

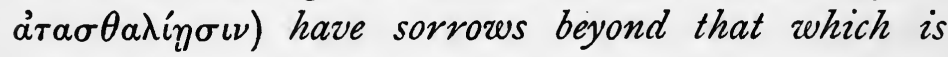
ordained ${ }^{1}$." This is the earliest suggestion of the second theory of evil with which we meet in Greek literature, viz. that evil is the result of folly, wrongdoing or sin for which man is himself responsible.

We are here reminded of the view expressed in the book of the Wisdom of Solomon: "God made not death; neither delighteth he when the living perish...but ungodly men by their hands and their

${ }^{1}$ Od. I. 33 ff. (after Butcher and Lang). 
words called death unto them ${ }^{1}$." Cleanthes the Stoic was thinking of the Homeric line when he wrote the verses:

\section{"O King of Kings}

Through ceaseless ages, God, whose purpose brings

To birth, whate'er on land or in the sea

Is wrought, or in high heavens' immensity,

Save what the sinner works infatuate."

And throughout Greek tragedy this view that God is the cause of all except what wicked men do of their own free will, is repeatedly insisted upon, not so much by Sophocles as by Aeschylus, who almost invariably tries to represent suffering as due to sin.

"For bursting into blossom, Insolence ( $v \beta \rho \imath s)$

Its harvest-ear, Delusion, ripeneth

And reaps a tearful fruit ${ }^{2}$."

But the theory that suffering always presupposes sin on the part of the sufferer himself, although it has the merit of simplicity, can hardly be said to square with facts, and many, if not most, of the objections to which it is liable are frequently urged in Greek literature.

Thus in the first place it is pointed out that in point of fact the wicked constantly enjoy prosperity, while adversity falls to the lot of the righteous. "Many wicked men are rich," says Solon, "and many virtuous men poor ${ }^{3}$." We meet with similar complaints in Theognis, who, more than any other of the elegiac poets, is perplexed and troubled by

1 I. $13 \mathrm{ff}$. See also Job iv. $7 \mathrm{ff}$.

2 Pers. 823 f., tr. A. Swanwick.

${ }^{3}$ Fr. 15, Bergk. 
the moral chaos of the universe. "Dear Zeus," he writes in one passage, "I wonder at thee: thou art the lord of all; thou hast great power and honour, and knowest well the thoughts of each man's heart. How then, son of Cronus, dost thou think fit to deal the same measure to sinful and to just alike, careless whether their hearts are turned to moderation or to insolence $\left(v^{\prime} \beta \rho \iota s\right)^{1}$ ?" Elsewhere he expostulates with the Almighty for bestowing wealth and honour on the wicked, in language that reminds us of the words of Jeremiah : "Righteous art thou, O Lord,...yet would I reason he cause with thee: wherefore doth the way of the wicked prosper? Wherefore are all they at ease that deal very treacherously ${ }^{3}$ ?" Also it is often pointed out that the innocent in this life constantly suffer along with the guilty, and even in place of the guilty. Greek elegy and Pindar in particular, and most of the Greek writers who touch upon moral problems at all, recognise the indubitable fact that the sins of the fathers are visited upon their children. Thus, for example, Solon, while affirming that the guilty are generally punished in their own persons at the last, nevertheless adds: "If the guilty escape, and the doom ordained of Heaven fall not upon themselves, it will surely fall hereafter; the innocent will suffer for the guilty, their children, perhaps, or later generations." Theognis emphatically questions the justice of this

$373 \mathrm{ff}$.

3 I2. $17 \mathrm{ff}$.
" Jer. xii. I. Cf. Theog. 743 ff. 
arrangement: "When the children of an unjust father," he exclaims, "follow after justice in thought and act, and dreading thy wrath, $\mathrm{O}$ son of Cronus, love righteousness from the first among their fellow-citizens, let them not pay for the transgressions of their sire! As it is," complains the poet, "the doer escapes, and another is punished ${ }^{1 . "}$ Here again we are reminded of the way in which the Hebrew prophets, Jeremiah and Ezekiel, fall foul of the doctrine that children are punished for the sins of their parents. "In those days," writes Jeremiah, "they shall say no more, the fathers have eaten sour grapes and the children's teeth are set on edge. But every one shall die for his own iniquity2." Still the fact remains that the innocent do suffer for the guilty, and this is enough to show that the theory which imputes suffering invariably to $\sin$ does not represent the facts of the case.

There is a further difficulty in the view which regards all suffering and calamity as only the punishment for sins committed by the sufferer himself. Granted that the sufferer has sinned, are we sure that he is himself responsible for his sins? In other words, is man a free agent, so far as virtue and vice are concerned? Unless we are free to choose, is it just that we should be rewarded for our virtue, or punished for our sin? This is a question which is constantly raised by Greek thinkers. Popular Greek theology ascribed everything to the Gods, including

$1737 \mathrm{ff}$.

${ }^{2}$ Jer. xxxi. 29 f. Cf. Ezekiel xviii. 
the origin of sin. Thus in Homer, Atê, Blindness or Infatuation, the Power that prompts to Evil, is the daughter of Zeus. When Agamemnon realises at last his criminal folly, he exclaims : "What could I do? It is God who accomplisheth all. Eldest daughter of Zeus is Atê who blindeth all, a power of bane: delicate are her feet, for not upon earth she goeth, but walketh over the heads of men, making men to fall: and entangleth this one or that ${ }^{1}$." And to much the same effect we read in a fragment of Aeschylus " that God engenders guilt in mortal men, when he purposes utterly to destroy their house." This fragment is quoted by Plato in the Republic $380 \mathrm{~A}$, and gives him occasion for an emphatic protest against ascribing evil to the Gods, except as a chastening visitation for the good of the sufferer.

It is a wide-spread notion throughout Greek literature that men are led astray into sin against their own free will by a daemon or divine spirit, which makes evil appear to them good, and good evil. Aeschylus speaks of an evil daemon or Alastor confounding men's senses and hounding them on to ruin: and in his most powerful tragedies, dealing with the history of $\sin$ as it reveals itself in the successive generations of a crime-stained family, the inherited tendency to $\sin$ is personified as a kind of congenital daemon, taking vengeance for the sins of the fathers by driving the children into sin. "In the hearts of evil men," he says, "sooner

$$
\text { 1 Il. 19. } 90 \text { ff., tr. Myers. "Fr. 156, Nauck. }
$$


or later, when the appointed hour arrives, the old Insolence or $\operatorname{Sin}(v \beta \rho \iota s)$ begets a young Insolence in the likeness of its progenitors, an avenging spirit or daemon, working in darkness, irresistible, unconquerable, unholy recklessness ( $\theta \rho a$ áos), bringing black destruction upon the house ${ }^{1 . "}$ This doctrine of a heaven-sent daemon or spirit leading men astray is obviously inconsistent with the theory of which I have been speaking, viz. that those who suffer have always sinned deliberately. An attempt is sometimes made to effect a kind of compromise between the two views. Thus, for example, Aeschylus, as it would seem, endeavours to distinguish two moments or stages in the career of the sinner: one when he commits the first transgression, and the other when he persists in his wickedness. Aeschylus appears to hold that it is in the power of the individual to refrain from taking the initial step; but as soon as he has transgressed, infatuation follows from the Gods, and his doom is sealed. This is the meaning of the well-known line in which the ghost of Darius moralises on the Persian down-

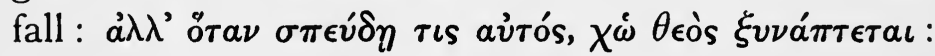
"when of our own free will we rush into sin, God himself becomes our ally"."

In the Old Testament, and in Aristotle ${ }^{3}$, we find parallels to this idea. In the Old Testament God is not the primary author of evil, but incites men to evil as a punishment for evil already committed ${ }^{4}$;

${ }^{1}$ Ag. 760 ff. ${ }^{2}$ Pers. 744 f. ${ }^{3}$ Eth. Nic. 1II. 7 III 4 a 19.

4 See Adam, Religious Teachers of Greece, p. $147 \mathrm{f}$. 
Aristotle holds that a man had power to refrain from the original acts which produced a vicious career, and consequently he says: "True, you cannot alter your character now; but it was open to you at first not to become wicked, and you are therefore voluntarily wicked." It cannot, of course, be argued that this is a satisfactory solution: for the real kernel of the difficulty lies in the contention that the original acts which laid the foundation of the habit were themselves not free, but the result of circumstance, heredity and so forth. And, so far as the Greek poets are concerned, I have already said that they constantly attempt to represent even the initial impulse to sin as coming from the Gods. "Hybris, Insolence or Sin," Theognis says, "is the first and greatest evil ; and God is its author."

3. A third suggestion with which we frequently meet in Greek writers is that suffering is a discipline intended by Providence to educate and improve the sufferer. The ordinary Greek view was perhaps that affliction makes the character deteriorate, as is shewn

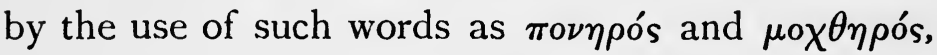
which passed from their original meanings, "painful" or "grievous," to a signification of moral depravity ${ }^{2}$.

$15 \mathrm{I}$.

2 [See however R. E. Macnaghten in Cl. Rev. for 1907, p. I2,

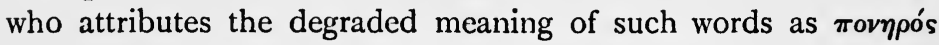
and $\mu \circ \chi \theta \eta p o$ s to an instinctive aversion to labour on the part of the Athenians. This "radical and permanent flaw" in the national character he regards as leading to the downfall of Athens. On this view toil would appear a calamity and would be as effective an agent of moral deterioration as sickness or other afflictions.] 
This doctrine is expressed by Simonides ${ }^{1}$, when he declares that "a man cannot but be bad, if hopeless

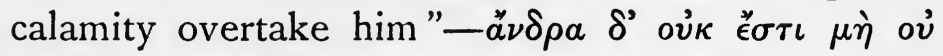

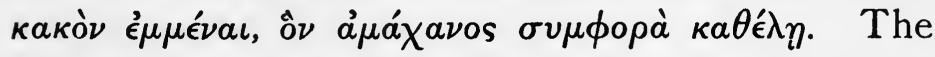
first writer, on the other hand, in whom the view that suffering is an education appears to any extent is Aeschylus, whom we saw also to have been the first to insist repeatedly on the error of ascribing evil to the Gods. "We learn by suffering" ( $\pi \dot{a} \theta$ os

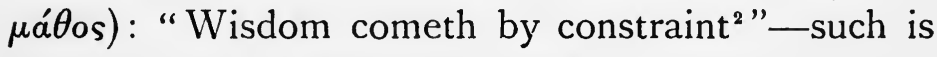
the language in which the poet expresses this idea, developing the old story $\pi \alpha \theta \dot{\omega} \nu \delta \dot{\epsilon}^{\prime} \tau \epsilon \nu \eta^{\prime} \pi \iota \iota^{\prime} \tilde{\epsilon}^{\prime} \nu \omega$. "It is Zeus," he says, "who guideth mortals on the road to wisdom, who hath appointed the sure ordinance-by suffering thou shalt learn. In sleep the anguish of remembered suffering breaks out before the heart-and wisdom cometh to mortals in their own despite." You may remember that we have exactly the same sentiments in the Book of Job. "God speaketh once, yea twice, though man regardeth it not. In a dream, in a vision of the night, when deep sleep falleth upon men, in slumberings upon the bed; then he openeth the ears of men, and sealeth their instruction, that he may withdraw man from his purpose, and hide pride from man." It is highly characteristic that Aeschylus should ascribe the law of $\pi a^{\prime} \theta o s \quad \mu a^{\prime} \theta$ oswe learn by suffering-to Zeus, the God of all others whom he most reveres. The stern old

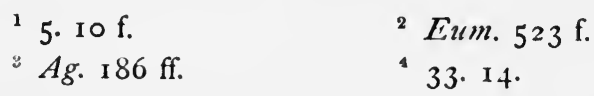


principle of simple retribution, $\delta \rho a ́ \sigma \alpha \nu \tau \iota \pi \alpha \theta \hat{\imath} \nu$, "the doer must suffer"-a principle on which he also insists with tremendous force-belongs apparently to the older dynasty of Gods who preceded Zeus: with Zeus a milder and humaner discipline begins.

The dramas of Sophocles sometimes illustrate the doctrine that suffering is a divinely-appointed means of education. $\mathrm{He}$ is quite clear that there is such a thing as unmerited suffering in the world; and he frequently represents such suffering in the light of a discipline. In the Oedipus at Colonus, Oedipus claims to have been taught by suffering and time.

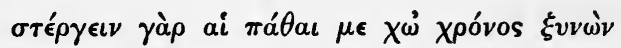

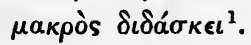

$\mathrm{He}$ is no longer the old Oedipus of Thebes, for, as Sophocles says in one of his fragments, "Much is revealed to the soul that is cradled in calamity":

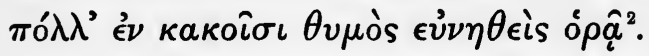

The same conception of suffering meets us also from time to time in Greek philosophy. Thus, for example, Plato, in the Republic, will not allow it to be said that God sends evil to mankind, unless by way of discipline, to improve and benefit the sufferer $^{3}$. So also in respect of suffering hereafter, Plato almost invariably represents it as curative or remedial-the after-life is a kind of purgatory,

${ }^{1}$ O. C. $7 \mathrm{f}$.

${ }^{2}$ Fr. 600, Nauck. See Adam, R. T. G., p. 172 f.

38 в. 
though it is true that some incurable evil-doers are punished in order to serve as examples for the rest of mankind, as for instance the tyrant Ardiaeus ${ }^{2}$, and one of the numerous suggestions made by Stoic writers as to the significance of suffering was that it is a $\gamma \nu \mu \nu a^{\prime} \sigma \iota \nu$ - a kind of training-ground for the development of character. Here again, of course, we find plenty of parallels in the Old Testament and Apocrypha, for example in the Wisdom of Solomon: "And having borne a little chastening, they shall receive great good; because God made trial of them, and found them worthy of himself. As gold in the furnace he proved them, and as a whole burnt offering he accepted them ${ }^{2}$." But the Greek writers do not, of course, pretend that such a theory offers a full solution of the mystery of suffering; it is merely one suggestion among many, and open to almost as serious intellectual difficulties as the others. It has been argued that a Power at once omnipotent and omnibenevolent could have bestowed on mankind the ultimate good which suffering is supposed to bring, and yet have dispensed with the suffering; and, from the purely rational point of view, it is difficult to discover an effective reply to the argument. On this account many thinkers, feeling themselves bound to surrender either the omnipotence or omnibenevolence of the Deity, have maintained the existence of two independent principles or powers - the one responsible for all that there is of evil in the world, and the other for the good. This
${ }^{1}$ Rep. 615 c.
${ }^{2}$ iii. 5 .
Cf. Job xxiii. 10. 
leads us to the fourth explanation of evil which appears in Greek literature, viz.

4. That evil comes, not from the Godhead, but from some rival principle or power, coeval with the Deity, for the most part working against him, and in any case not yet, at least, completely subject to his control. In other words, the existence of evil is explained on the hypothesis of dualism.

I have already said that we seldom, if ever, meet with this view in Greek poetry; but it occurs from time to time in Greek philosophy. At first, indeed, the philosophers endeavoured to explain the universe by postulating a single uncreated and imperishable substance, water, it might be, or air or fire; but in course of time these two principles began to be recognised; and the tendency grows up to regard one of them as the cause of good, the other as the cause of evil. Empedocles derives the Universe from the four elements, Fire, Air, Water and Earth, together with the two efficient or moving causes Love and Hatred, the former of which combines the elements into things, while by the latter things are resolved again into the elements. He clearly looks upon Love as the beneficent, and Hatred as the maleficent power; and in the judgment of Aristotle, the conception at which he is really driving, though he fails to give it adequate expression, is that Love is the cause of good, and Hatred of evil; so that in a sense Empedocles was the first to recognise the Good and the Evil as two distinct and independent principles; for of course 
that which causes good is the Good, and that which causes evil the Evil. Anaxagoras was a much more consistent and thorough-going dualist. He derives the world from the action of Mind or Reason, $\nu$ ovs, upon primeval chaos: all things, he says, were together-ó $\mu о \hat{v} \pi a ́ \nu \tau a ~ \chi \rho \dot{\eta} \mu a \tau a \hat{\eta} \nu$-then Reason came and formed them into a cosmos- $\epsilon \hat{\boldsymbol{i} \tau \alpha} \boldsymbol{\nu} \nu \hat{v} \boldsymbol{s} \dot{\epsilon} \lambda \theta \dot{\omega} \nu$ $\delta \iota \epsilon \kappa o ́ \sigma \mu \eta \sigma \epsilon \nu$. But he did not, so far as we know, ascribe the evil in the world to the one principle -I mean to pre-existent chaos-and the good to Reason, although the position which the worldforming $\nu 0 \hat{v}$ occupies in his system is analogous to that which later theology assigns to the Deity, even if, as is probable, he did not call vous the Deity. Reason, in Anaxagoras, is uncreated and imperishable, at once omniscient and omnipotent, apparently a spiritual and not a corporeal essence, a power that, in virtue of its absolute freedom-it is, as he says, avंroкрат'́s-creates the cosmos. It is not until we come to Plato that we seem to find evil expressly attributed to a principle apparently coeval with, and clearly, I think, distinguished from the Good. In his Timaeus, Plato declares that the World as we see it is a mixed creation-the product of Mind or Reason and Necessity. The subject is one on which different views have been held, but to me it seems clear that Necessity, to which Plato attributes whatever there is of evil in the world, is a personification of the original matter or chaos, out of which the Deity constructs the universe. In any case, Plato makes it clear that 
the Creator had not quite a free hand. He constantly repeats that God, desiring all things to be beautiful and good, made them beautiful and good, as far as possible. The qualifying phrase "as far as possible" clearly implies the presence of some impediment, some power or principle extraneous to the Deity, which he cannot wholly overcome. For the most part, Plato connects this rival principle with what is material and not with the spiritual. Thus in the Theaetetus he writes: "Nay, Theodorus, evil can neither perish (for there must always be something opposed to the Good), nor yet can it be situated in heaven; but of necessity- $\boldsymbol{\epsilon}^{\prime} \xi \alpha^{\prime} \nu a^{\prime} \gamma \kappa \eta s-i t$ haunts our mortal nature and this present world ${ }^{1}$." But, in a well-known passage of the Laws, he affirms that there is an evil world-soul as well as a good-two cosmic souls, the one beneficent, and the other maleficent, contending against each other throughout the whole domain of nature. This is perhaps the nearest parallel in Greek literature to the conception of a devil ; only in Plato the evil worldsoul would appear to be altogether independent of the good, so far as concerns its origin.

The Stoic philosophers occasionally explain the presence of evil in a somewhat similar way, although, as we shall presently see, the most characteristic and consistent Stoic solution was of quite a different kind. Thus Chrysippus declared that there was a large admixture of Necessity in the world-and Necessity, in Greek thought, is always something evil as op- 
posed to Nature, which is something good; while at other times he suggested that perhaps God is not

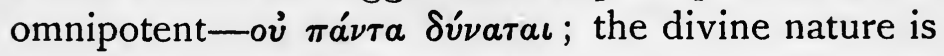
not altogether free from weakness ( $\dot{\sigma} \sigma \theta \dot{v} \boldsymbol{\prime} \epsilon \iota)$, and hence, along with the good things which he makes, a certain amount of evil is bound up per sequellas quasdam necessarias, as Gellius says ${ }^{1}$, by a sort of necessary or inevitable law which the Deity himself cannot escape.

This dualistic explanation of the origin of evil is of course the simplest; and it is worth our while to observe that it provides a solid foundation for morality. The notion is that God is the altogether beneficent power always at work in the world against the forces that make for evil; and it is further implied that man for his part is a composite creature, with an element of the divine in him, and at the same time with something of the Titanic or devilish-standing midway between mortality and immortality, "With th' one hand touching heav'n, with th' other earth"."

The duty of man is thus to become a co-worker

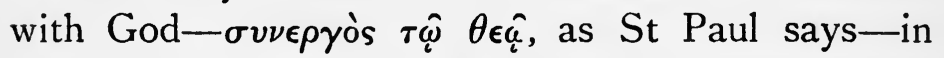
the attempt to establish a kingdom of heaven both within himself and in the world ${ }^{3}$. To this thought Plato gives a characteristically religious expression

${ }^{1}$ Aul. Gell. Noct. Att. vir. I. 9.

${ }^{2}$ See the lines of George Herbert, quoted supra, The Vitality of Platonism, p. $2 \mathrm{r}$.

${ }^{3}$ From the Euthyphro we gather that piety is the art of

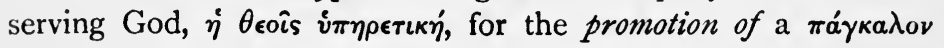
ëp pov, namely virtue, I $3 \mathrm{E}$. 
in a striking passage of the Laws, thus translated by Jowett: "For as we acknowledge the world to be full of many goods and also of evils, and of more evils than goods, there is, as we affirm, an immortal conflict going on among us, which requires marvellous watchfulness; and in that conflict the Gods and demigods are our allies"- $\xi \dot{v} \mu \mu a \chi o \iota ~ \delta \grave{\epsilon}$

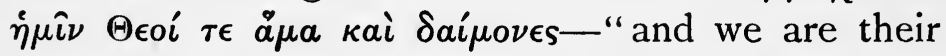
property." The guise under which humanity here presents itself is that of warfare-warfare as the condition of progress; and it is just the presence of evil which makes the warfare possible. In this way a dualistic theory of the world may afford a basis for morality. But, although Manicheanismfor such in effect this explanation of evil really ismay be satisfactory to the intellect, it somehow fails to satisfy man's spiritual and emotional nature -we long for unity-and it sacrifices, of course, the omnipotence of the Godhead. On this account the most religious characters, especially those of a mystical tendency in ancient as well as in modern times, have seldom been able to acquiesce in such a theory; and it only remains for me to touch on the kind of solution which, though not, perhaps, intellectually invulnerable, has commended itself to not a few of the religious teachers of mankind.

5. In a certain line of the Iliad the Gods are said to pledge one another in golden goblets as they look upon the battle of Greeks and Trojans round Troy ${ }^{2}$. On this line a scholiast writes the

${ }^{1} 906$ A. See also supra, p. 163.

2 4. 4. 
following note: "Men say it is unseemly that the sight of wars should please the Gods. But it is not unseemly; for noble deeds give pleasure. Besides, wars and battles appear terrible to us, but to God even these are not terrible. For God accomplishes all things with a view to the harmony of the whole, dispensing what is expedient thereunto, even as Heraclitus says that to God all things are beautiful and good and right, but men consider some things wrong and others right." The fifth theory of suffering and evil is contained in this extract, and goes back, as you will see, to Heraclitus. Briefly stated, it is this. Man's point of view is limited: he sees only a part. Hence to us the evil and suffering in the world appear a blot; but if we could see the whole, if we could attain to the universal point of view, the point from which God himself regards the universe, we should see that evil and suffering contribute to the universal harmony. For this universal harmony results from the play of opposites: "as with the bow and the lyre," says Heraclitus, "so with the world; it is the tension of opposing forces that makes the structure one." "Opposition," we are told, " is cooperation"; "the fairest harmony results from differences"; "were there no higher and lower notes in music, there could be no harmony at all." It is the same kind of view which Browning adumbrates in Francis Furini ${ }^{2}$.

Plato in antiquity occasionally gives expression to a similar view, as when he says that God created
${ }^{1}$ Her. Fr. 6r, Bywater.
${ }^{2}$ Quoted supra, p. 166.

A. E. 
the part for the sake of the whole, and not the whole for the sake of the part-a sentiment that looks like an echo of the words of Heraclitus-" God accomplishes all things with a view to the harmony of the whole." Traces of this idea are perhaps to be found also in Aeschylus. It may be that the poet intends us to believe that the spirits of cursing in the Eumenides are, really, if we could only see it, spirits of blessing. Sophocles, too, "seems to invite us to lift our eyes from the suffering of the individual to a consideration of the ulterior purpose which Providence is thereby seeking to fulfil.... But it is not only the life of the individual that the poet thus regards. He seems to have extended his outlook to the whole movement of the human destiny, and to have seen therein the fulfilment of a single harmonious purpose, which is none other than the will of Zeus'."

But the Stoics were the chief representatives of this view in ancient times ${ }^{8}$. Man's true and essential individuality, according to this school, is realised in the service of that universal being which they identified with God; and, further, it is God who is himself the ultimate unity in whom all the opposition and variety of the Universe is reconciled".

If, in conclusion, we try to estimate the ethical

${ }^{1}$ See Verrall's edition, p. xxxv.

Adam, R. T. G., pp. I 73, 175.

${ }^{3}$ See supra, Hymn of Cleanthes, pp. $166 \mathrm{ff}$.

+ See Hymn of Cleanthes, 1. I 8 ff., and Keble's lines quoted supra, p. I69. 
and religious value of this attempted explanation of the problem of suffering and evil-an explanation which appears again and again in nearly every form of pantheistic thought, and more especially in Spinoza-we must distinguish, I think, between physical evil on the one hand, and moral evil on the other. So far as physical evil is concerned, the suggestion that pain and suffering do in some mysterious way, if we could only see it, fulfil the divine purposes and contribute to the harmony of the whole, may not be satisfactory to the intellectit seems, indeed, to shelve the intellectual difficulty altogether-but experience shows that it is a source of consolation and resignation to the sufferer. But the explanation of the existence of moral evil on the same theory does not satisfy either our intellect or our religious feeling. The Stoics indeed sometimes maintain that moral evil is needed in the universe to give a meaning to moral good, because temperance, for instance, implies intemperance, justice injustice, truth falsehood and so forth ${ }^{1}$, but we feel that moral good and moral evil are fundamentally opposed to one another: so that there can be no real harmony or unification of the two.

These, then, would seem to be the principal views expressed in Greek literature on the subject of suffering and evil. Let me briefly sum up. At first, suffering is ascribed directly to the operation of the Gods; secondly, it is represented as due to $\sin$; in the third place, it appears as a divinely

${ }^{1}$ See supra, Hymn of Cleanthes, pp. $169 \mathrm{ff}$. 
ordained discipline for the improvement of the character; in the fourth place, a frankly dualistic explanation is attempted, evil, both physical and moral, being attributed to a malevolent, and good to a benevolent being; and finally, a few thinkers show a disposition to hold that the distinction between good and evil is one of merely human making, and that from the highest standpoint all is good. We cannot in this world see the true harmony of the universe, but among the Greeks there are many signs of a firm belief in its existence; and of the hope of a hereafter in which the mystery shall be solved, for

"Death is the veil which those who live call life; They sleep and it is lifted."

1 Shelley, Prometheus Unbound. 


\section{VI.}

THE MORAL AND INTELLECTUAL VALUE OF CLASSICAL EDUCATION.

A former student of Classics at the University, who is now earning an honourable if somewhat scanty livelihood by teaching Greek and Latin somewhere in the provinces, once remarked to the writer of this essay, a propos of the curriculum of classical study in Cambridge, "Cui bono? When I die, I should like to have the words Cui bono? engraved upon my coffin." The same inquiry, expressed perhaps with less playfully pathetic exaggeration, must occasionally be addressed to every teacher of the Classics. It is a question which ought not to be evaded, whether it comes from the advocate of some rival scheme of education, or from the dejected pupil vainly struggling to descry the wood among the trees. A variety of answers has often been returned ${ }^{2}$, and not without good reason, because the answer necessarily differs

${ }^{1}$ Several of them are discussed (and somewhat severely handled) by Professor Sidgwick in Farrar's Essays on a Liberal Education, pp. 81-143. 


\section{The Value of Classical Education}

according to the status of the questioner. It would be inappropriate, for example, to offer the same answer to a Senior Wrangler who is urging the rival claims of mathematics, to a boy who is learning Latin for the purposes of an apothecary, and to a classical student at Oxford or Cambridge. We are therefore at liberty to attempt a partial reply, addressed in the main to those who are familiar with the routine of classical study as it is pursued in the Universities. It is in these that classical education is carried to its highest pitch; and consequently any theory of classical study at the Universities, if even approximately true, will be at once more fundamental and more final than one whose scope is limited to an earlier stage in the intellectual and moral training of the student. If classical education is to retain its hold upon the Universities, - and the recent development of other studies has but strengthened its position ${ }^{1}$,-it must be prepared to invite the student into more spacious and more fruitful fields of inquiry than can profitably be worked at school. The present Essay is only an attempt to sketch in outline what seems

1 The following passage from Mark Pattison's Essays (vol. I., p. 440) will show that such a result might have been anticipated, if only-as we shall endeavour to show-the study of the classics is essentially a liberal education. "It is a well-established fact in the history of liberal education, that the periods in which the history and the practice of it have made the greatest improvement, have been periods immediately succeeding some of the great discoveries in science, or some of the great impulses to the study of facts." 
to the author a true apology and theory of the place and proper function of classical study in a University.

Let us begin by availing ourselves of a distinction of long standing-a distinction at once popular and scientific-the distinction between what is called a liberal and what is called a professional education. The distinction was familiar to the ancients; in Plato's day, the teachers of liberal education were the philosophers and dramatists and artists, whereas professional training was supplied by the sophists.

Speaking generally, we may say that the primary object of a professional education, now as in antiquity, is not to develop the mental and moral qualities of the pupil for their own sakes, but to enable him to make his living - to convert, in other words, his brains into money. Training of this kind may or may not incidentally advance the liberal education of the learner, but in its essence it is altogether distinct from liberal education, because its end and aim are different.

To give an exhaustive definition of liberal education lies beyond our present scope, but we will mention two points in which the man of liberal education-i $\pi \epsilon \pi a \iota \delta \epsilon \nu \mu \epsilon$ vos, in the strict sense of the word $\pi a i \delta \epsilon^{\prime} a-$ differs from the man whose education is otherwise.

In the first place, liberal education implies the power of intellectual sympathy. The faculty of entering into another man's thoughts, of appre- 
ciating his point of view, and recognising the inherent necessity of his creed and conduct, belongs only to the man who is liberally educated. In dealing with their fellow-men, others are tyrants and persecutors; he alone is tolerant. Nor is his intellectual sympathy confined to the circle in which he moves. He can enter into the thoughts and feelings which prevail or have prevailed in another nation and another age, and move among the mighty minds of every generation as if they were his kindred. Liberal education communicates this faculty of intellectual sympathy because, being itself rather the Form than the Matter of knowledge, it enables us in dealing with the thoughts of others to make them our own by clothing them with the form which we already know. From this point of view liberal education is to every other kind of learning just what Logic is to the Sciences.

In the second place, liberal education involves the training of the character no less than of the intellect. It aims at the $\pi \epsilon \rho \iota \gamma \omega \gamma \eta^{\prime}$ of the entire

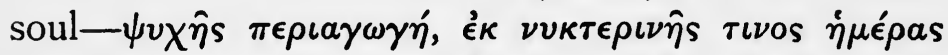

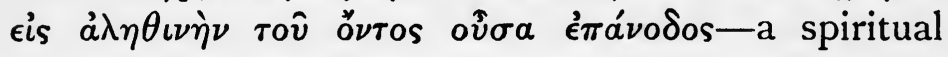
revolution, in which the soul ascends from twilight to the noonday of reality ${ }^{1}$. True, the educator addresses himself to the intellect of his pupil first and foremost, but he does not desire, nor is it, from his point of view, even possible, to influence the intellect without affecting the will and character.

1 Plato, Rep. viI. $5^{21} \mathrm{c}$. 
He addresses himself in short, not to the intellect alone, but to the whole man through the intellect. His attitude may be described in the words of

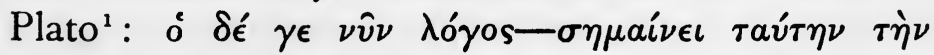

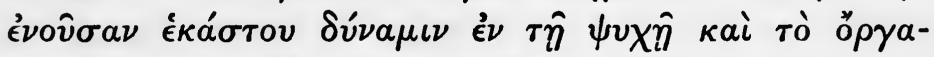

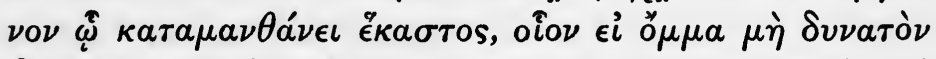

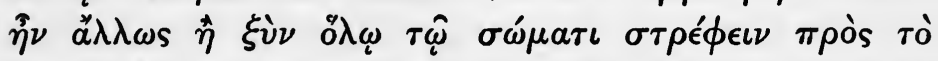

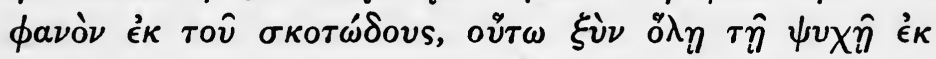

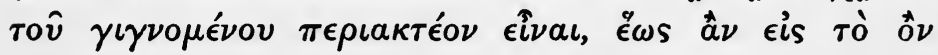

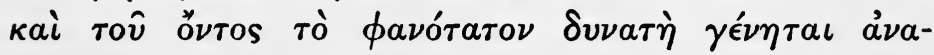
$\sigma \chi \epsilon ́ \sigma \theta a \iota \theta \epsilon \omega \mu \epsilon \in \bar{\nu} \eta$ : "Our present reasoning indicates that this faculty" (meaning vov̂s or reason) "dwelling in the soul of each individual, this organ wherewith each one learns, cannot be turned round from gazing on the false and fleeting, and rendered able to endure the contemplation of truth and the brightest part thereof, except by turning the whole soul round-even as if it were impossible to turn the bodily eye from darkness to light except by turning the whole body round along with it."

Confining ourselves then for the present to these two features of a liberal education-its power to produce intellectual sympathy, and its effect in moulding the character through the intellect-let us inquire whether the study of the Classics can justly be regarded as a liberal education, when judged by these two canons.

What is Classical Education? We may say briefly that it is the transportation of the mind into the ways of thought and feeling which pre-

$$
{ }^{1} \text { Rep. vil. } 518 \text { c. }
$$


vailed in ancient Greece and Rome. This is a high ideal; but nothing short of this will donothing short of this has been aimed at by $\mathrm{Hu}$ manists in every generation. Macaulay used to define a scholar as the man who could read his Plato with his feet upon the fender; but that is not enough. It was said of $\mathrm{Dr}$ Kennedy that when he took a class in Demosthenes he did not teach Demosthenes, he was Demosthenes. It is in the same sense that the true scholar always identifies himself with the author whom he reads. In proportion as he grasps the full meaning of the Greek, he transcends the limitations of time and place, and is carried back into the world wherein his author lived and moved. The soul of Homer, of Plato, of Sophocles, of Virgil passes into him; he looks out with other eyes upon another world; and the very music of their language seems to him the spontaneous utterance of thoughts that are not theirs, but his. Nor is it only in the reading of authors that such a transportation of the soul is necessary in order to derive the full benefit of a classical training. The writing of Greek and Latin prose and verse is truly valuable only in so far as it enables us to see with the eyes, hear with the ears, and think with the minds, of the ancients. No man ever wrote like Plato or like Cicero unless the spirit of ancient philosophy or oratory dwelt within him at the time. The same is true of the study of classical syntax and grammar. The Grammarian is of little value to the Humanist if he does 
not show him what particular habit of mind or feeling prompted the ancients to express themselves in such and such a way. It has often been observed that language stands to thought as form does to matter. Now if there is one thing more characteristic of Greek civilisation than any other, whether we consider its religion, its philosophy, its art, or its politics, it is the intimate union which everywhere existed between matter and form. In dealing with the relation of language to thought, Plato expressed his consciousness of this union by describing language as the image $(\epsilon i \delta \omega \lambda o \nu)$ of thought, and thought as nothing but the inner language of the soul conversing with herself. This is the justification of that laborious study of words, and syntax, and idiom, which no serious student of the Classics can afford to neglect. We desire to recreate the world of Plato and Sophocles, to see what they saw, as they saw it, think what they thought, as they thought it; and in the wonderful language which they spoke, there is no shade of expression, however delicate, no particle, however trivial, in which there may not lurk a subtle force, to miss which is to fall short of apprehending the full significance of ancient life and thought. We need hardly add that History and Archæology lose half their charm and all their educational value unless they teach us how the ancients lived and felt. Modern historians sometimes forget that History is one of the Muses: the ancients seldom did. It is not every archæologist who can see, 
like Keats, the whole soul of Greek antiquity in a Grecian urn :

"O Attic shape! Fair attitude! with brede .

Of marble men and maidens overwrought, With forest branches and the trodden weed;

Thou, silent form! dost tease us out of thought

As doth eternity! Cold Pastoral!

When old age shall this generation waste,

Thou shalt remain, in midst of other woe

Than ours, a friend to man, to whom thou say'st,

Beauty is truth, truth beauty, that is all

Ye know on Earth, and all ye need to know."

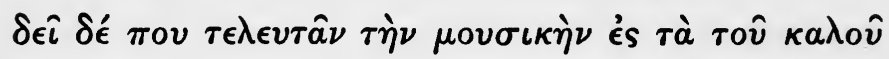

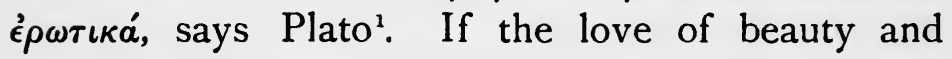
truth is the ultimate goal of all education-and if the outward beauty of form and shape, whether it appeals to us through language or through sculpture, is but the expression of the spiritual loveliness within,-then our study of antiquity should be psychological. Classical study, in point of fact, so far as it is an educative discipline, is a department of Psychology, the crown of sciences, according to Professor Bain.

We may take it then that education in the Classics involves, or should involve, the transportation of the mind into the sphere in which the ancients lived and thought and felt.

It remains to ask, Does such a transportation fulfil the two conditions of liberal education which we have laid down? Does it promote intellectual sympathy? Does it refine and strengthen the character? 
Before describing his curriculum of education, Plato lays it down, in the seventh book of the Republic ${ }^{1}$, that whatever presents us with two opposite sensations at one and the same time is calculated to stimulate the intellect. By an extension of this principle we may say that any department of study which continually presents us with ideas and emotions antagonistic to the age in which we live tends forcibly to awaken our intellectual activities and foster intellectual sympathy.

Now this is precisely what the study of classical, and especially of Greek, antiquity preeminently does. The literatures of Greece and Rome are the only great and easily accessible literatures which remain to us before the foundation of Christianity and modern civilisation. In reading Greek and Latin authors, if only we read them intelligently, we stumble throughout almost every page upon some mode of expression, upon some idea, foreign to the fashion of to-day. The effect is, or should be, what Socrates described as an intellectual torpedo-shock, similar to that produced upon the body by contact with the torpedo or cramp-fish. You are stunned at first-or, as Plato might say, dazed, and rendered giddy, by the contradiction; but the paralysis soon disappears, and your intellect begins to resolve the contradiction into a higher unity, involving a broader, more charitable, and for that reason more profound, conception of human nature and human life. "The main object," says Mr Bowen, in Essays on a Liberal Education",- " the main object of seeing

$$
{ }^{1} 524 \text { D. } \quad{ }^{2} \text { p. } 194 .
$$


distinctly what Plato and Cicero thought, is that one may be able to look on all questions, not only on the side which they now present, but on that also which they turned to observers long ago; to gain, as it were, a kind of intellectual parallax in contemplating the problems of life."

Let us give one or two examples of the kind of contradictions which we have in view. We shall not attempt to resolve them; to do so would be to stray into the deepest questions of philosophy, and it is an integral part of classical education that every one should sooner or later-later rather than sooner-devise a solution of his own. The examples which we shall select are from Greece more often than from Rome.

If one were to endeavour to express in a single word the fundamental difference between ancient and modern ways of thinking, one might say that the keynote of the former is synthesis, that of the latter analysis. The ancients delighted in wholes; the moderns delight in resolving a whole into its component parts. It is only another way of expressing the same essential difference to say that Greek antiquity was on the whole imaginative, while modern life is scientific in the main. Now the greatest whole which it is possible to conceive is the totality of things, composed of the ego and the non-ego, of internal and external nature, of the Individual and the World. As regards the relation

${ }^{1}$ See Tyrrell, Latin Poetry, pp. 85,96 , as to the value of contrasts. 
between these two, the Greeks regarded Man and Nature as united in a far closer union than we do now. Nature was to them no step-mother, no tigress, "red in tooth and claw," no inhuman force to be fought against, but a mother, a beneficent power with whom we should cooperate against the forces that make for misery and sin. It was not, we may well believe, to pray to his goddess mother only that Achilles turned to the sea for comfort:

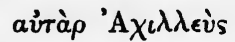

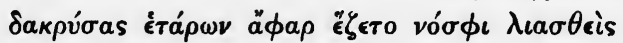

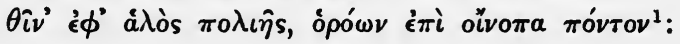

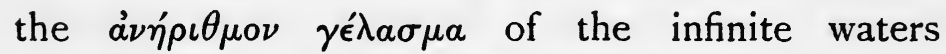
soothed and consoled his troubled heart. Nothing could illustrate more finely the Greek sentiment of kinship-if we may say so-with the sea than Simonides' picture of Danae and her babe cast adrift upon the stormy waves. The words of Danae are full of peace and quiet faith: fear is the least of her emotions. Hear what she says, addressing her child:

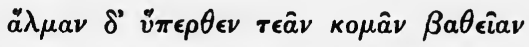

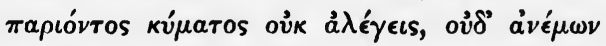

$\phi \theta o ́ \gamma \gamma o v, \pi o \rho \phi v \rho \epsilon ́ a \iota \sigma \iota v$

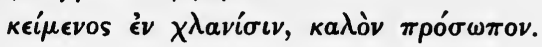

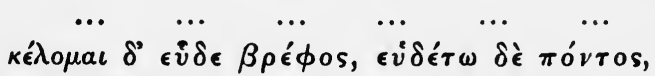

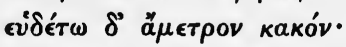

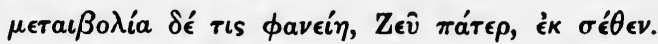

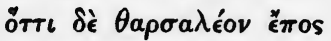

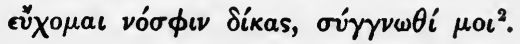

1 Homer, Il. I. 348-350.

2 Simonides, 37. 
"Sleep, my babe, and sleep, the sea!" The sympathy of human with external nature was never more touchingly expressed. And what shall we say of Earth, the Mother? The elder Pliny ${ }^{1}$, in one of the noblest passages in the whole range of Latin literature, has interpreted for us the ancient feeling of love and affection for the mother who feeds and sustains us during life, and recalls us to her arms at death: "Sequitur terra, cui uni rerum naturae partium eximia propter merita cognomen indidimus maternae venerationis. Sic hominum illa, ut caelum dei, quae nos nascentes excipit, natos alit semelque editos sustinet semper, novissime complexa gremio iam a reliqua natura abdicatos, tum maxime ut mater operiens, nullo magis sacra merito quam quo nos quoque sacros facit, etiam monumenta ac titulos gerens nomenque prorogans nostrum et memoriam extendens contra brevitatem aevi, cuius numen ultimum iam nullis precamur irati grave, tanquam nesciamus hanc esse solam quae nunquam irascatur homini. Aquae subeunt in imbres, rigescunt in grandines, tumescunt in fluctus, praecipitantur in torrentes: aer densatur nubibus, furit procellis; at haec benigna, mitis, indulgens, ususque mortalium semper ancilla, quae coacta generat, quae sponte fundit, quos odores saporesque, quos sucos, quos tactus, quos colores!" "Tum maxime ut mater operiens," "then most of all like a mother covering us "-do not these words remove Death's sting? ó $\delta \dot{\epsilon}$

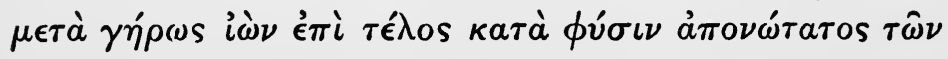
Hist. Nat. II. 63 . 


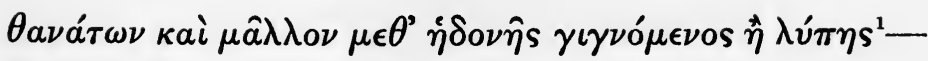
death in the course of nature is accompanied rather by pleasure than by pain. The wearied child returns to his mother's arms at evening :

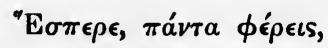

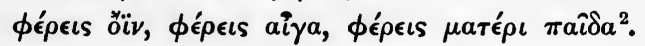

But such a picture of Death, beautiful as it is, was rare among the Greeks. We may welcome the God when he comes as the natural evening of a happy day; the miserable may pray for him to come "with healing in his wings," as in the touching lines of Aeschylus ${ }^{3}$ :

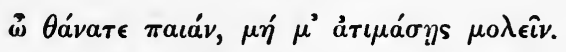

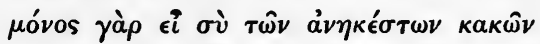

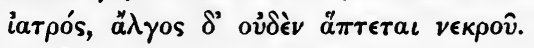

But how seldom does Death delay his advent till the natural bourn!

modo pueros, modo adulescentes in cursu a tergo insequens necopinantes adsecuta est ${ }^{4}$.

Nor could the Hellenic joy of living always look forward with resignation even to the natural term of life. The well-known lines attributed to Moschus represent the usual Greek feeling about death:

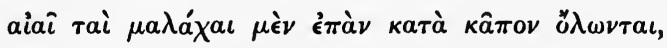

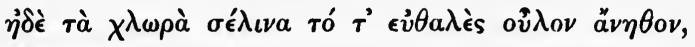

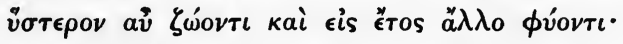

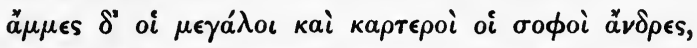

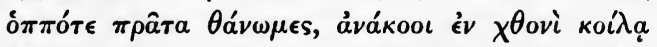

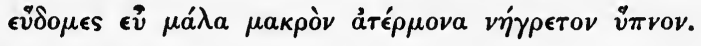

${ }^{1}$ Plato, Timaeus, 8 I E. $\quad{ }^{2}$ Sappho, 95. $\quad{ }^{3}$ Fr. 255 , Nauck. 4 ap. Cicero, Tusc. Disp. I. 94. See also Tyrrell, Latin Poetry $76 \mathrm{ff}$, I $17,159 \mathrm{ff}$.

A. E. 
The Greeks murmured at death because it seemed to involve a breach with the order of nature. The leaf dies, but the soul still lives, and clothes itself in another body in the spring; but man perishes, or if his soul survives in Hades, it is but a shadow in shadow-land, a prisoner sighing for freedom and the light of day ${ }^{1}$. The dead Achilles was but the mouthpiece of Greek feeling when he said $^{2}$ :

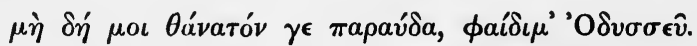

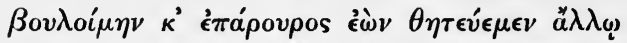

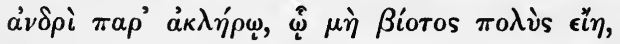

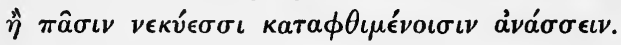

But do not let us call the Greeks melancholy on this account ; it is easy to exaggerate what is called their melancholy. Their repugnance at death is the measure of their optimism and love of life. A Greek could hardly have written the exquisite lines of Keats, in the Ode to a Nightingale:

"Darkling I listen; and for many a time

I have been half in love with easeful Death,

Call'd him soft names in many a mused rhyme,

To take into the air my quiet breath;

Now more than ever seems it rich to die,

${ }^{1}$ It is interesting here to note how the theory of transmigration (involving a return to life upon the earth, the soul clothing itself in a new body as the tree puts forth new leaves) - the form in which the doctrine of immortality impressed itself upon the deeper religious and philosophical feeling of the Greeks-implies a reconciliation with the order of Nature as seen in the life of plants.

${ }^{2}$ Od. XI. $488-49$ I. 
To cease upon the midnight with no pain, While thou art pouring forth thy soul in ecstasy! Still would'st thou sing, and I have ears in vain, To thy high requiem become a sod."

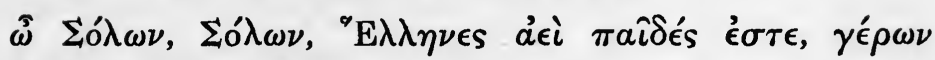

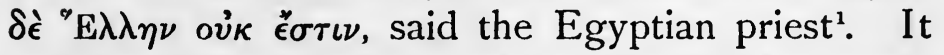
was the eternal boyhood of the Greeks that made them shrink from death as something almost contrary to Nature.

Up to the present point, we have dealt with the Greek conception of Nature and natural forces as personified, perhaps, but not as deified. But to the common people and the philosophers alike, Nature was divine. The popular imagination peopled earth and sea and sky with multitudinous gods and goddesses, the personification of natural forces, but did not unify them in the conception of a single allembracing Deity. Throughout Greek literature, on the other hand, or at all events in the best Greek literature which survives, there runs an undercurrent of monotheism, and the philosophers loved to represent the totality of Nature's forces as the one and only God. And as God is good, so likewise is

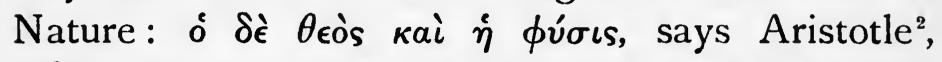

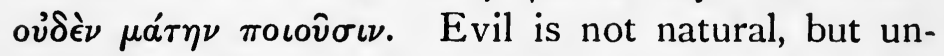

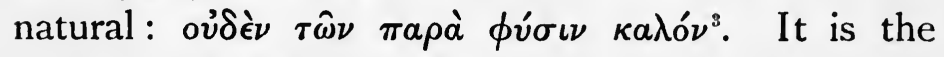
background of Necessity or Fate which throws into relief the smiling face of Nature ${ }^{4}$. And what the

1 Plato, Tim. 22 в.

2 De Caelo, 27 I $^{\mathrm{a}} 33$.

${ }^{3}$ Ar. Pol. $1325^{\mathrm{b}} 9 \mathrm{f}$.

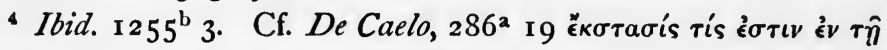

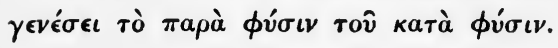


Greeks believed of Nature as a whole, they believed of Human Nature. Man's nature is not corrupt, not fallen, not degraded: there is no such thing as "Original Sin": there is no cleft between the human and the divine, no aching sense of sin, no need of a reconciliation with God: $\dot{\epsilon} \nu$ ả $\nu \delta \hat{\omega} \nu$,

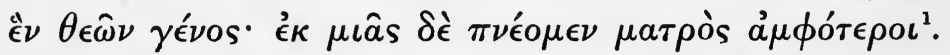

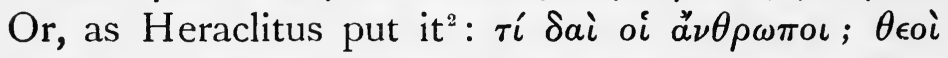

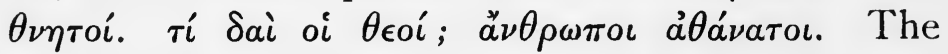
most genuinely Greek expression of the ethical end is "the life according to Nature": the highest practical expression of Greek religion is-as it is well expressed by Zeller- "to do to the glory of God that which is according to our own nature."

It is unnecessary to dwell at length upon the contrast between such views and those under whose

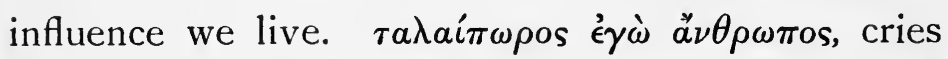

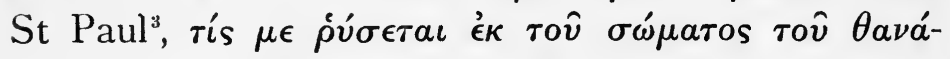
rov rov́rov; We can hear the birth-cry of a new religion in these words. Nature and man have strayed from God: Christianity will lead them

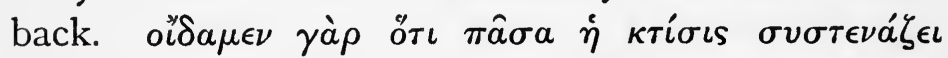

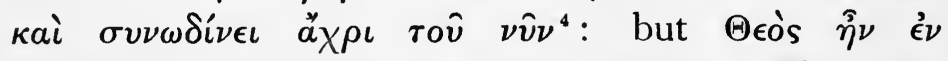

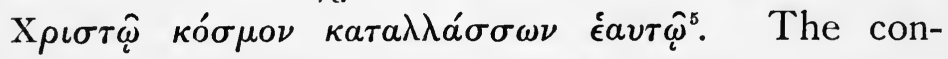
trast between Paganism and Christianity could not be more strikingly expressed than in the words of

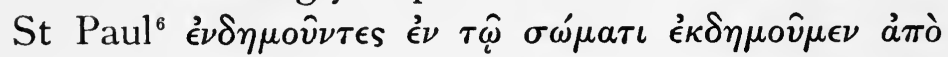
1 Pind. Nem. vi. I.
2 Fr. 67, Bywater.
3 Rom. vii. 24.
4 Rom. viii. 22.
52 Cor. v. 19.
${ }_{6} 2$ Cor. v. 6. 


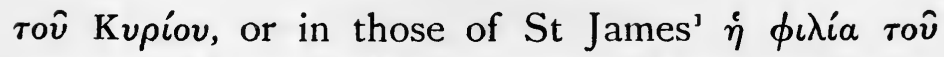

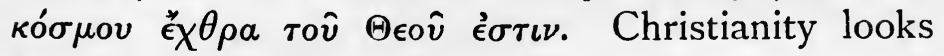
for a city, not on earth, but in the heavens: $\dot{\eta} \mu \hat{\omega} \nu$

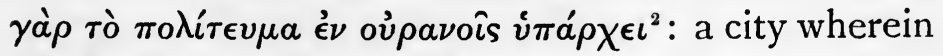

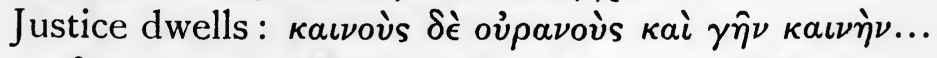

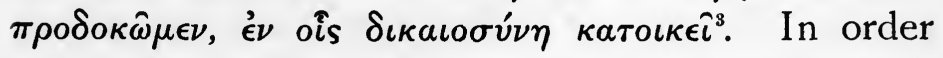
to become a citizen of this Ideal City-

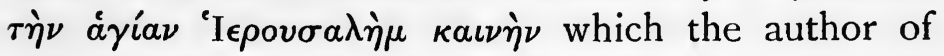

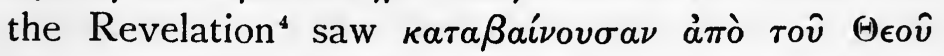

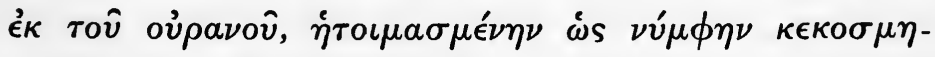

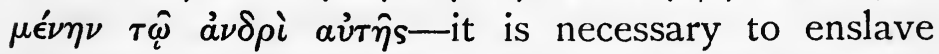
the body and make free the soul: $\alpha \lambda \lambda^{\prime} \dot{v} \pi \omega \pi \iota \iota^{\prime} \zeta \omega$

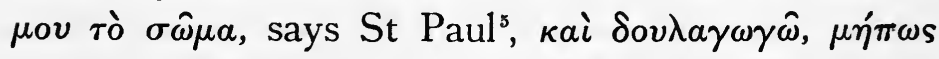

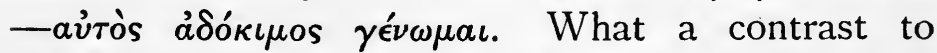
the Hellenic attitude is here! $\mu \grave{\eta} \theta \eta \sigma a v \rho i \zeta \epsilon \tau \epsilon \dot{v} \mu \hat{\imath} \nu$

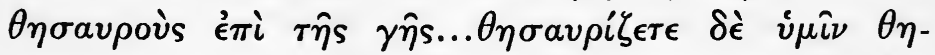

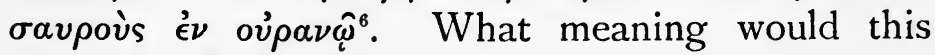
sublime exhortation have conveyed to an ordinary Athenian in the time of Pericles? The Hellenic vista-

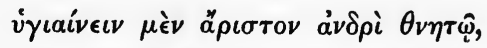

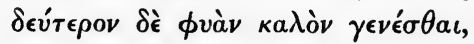

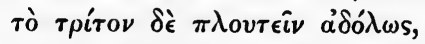

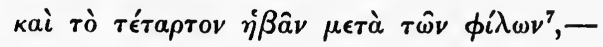

ends where the full fruition of the Christian begins -at death. The correct appreciation of this fundamental contrast is one of the most potent factors
1 iv. 4 .
2 Phil. iii. 20.
32 Pet. iii. 13.
4 xxi. 2.
5 I Cor. ix. 27.
${ }^{6}$ St Matt. vi. 19.
7 Ath. Xv. 694 e : cf. Plato, Gorg. 45 I E. 
which can be conceived in the promotion of intellectual life and sympathy'.

Let us take another illustration from the sphere of man's duty to his fellows. The traditional morality of Greece laid it down as a rule of conduct to do good to friends, and evil to foes. We except for the present the protests raised by Plato and one or two others ${ }^{2}$ against this precept of Greek morality; in this, as in many other matters, Plato's teaching is the morning twilight of a brighter day. Solon ${ }^{3}$ prays that he may be "sweet to friends, and bitter to foes": Pindar ${ }^{4}$ is fain "to love a friend," but $\pi$ o $i$

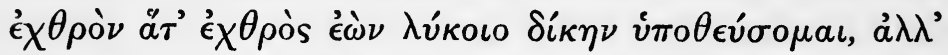

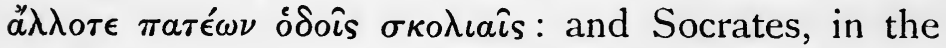
Memorabilia ${ }^{5}$, represents this principle as the prevailing morality of Greece. Set against this the

${ }^{1}$ It is of course easy to find in Socrates, Plato, and Euripides, and sporadically elsewhere, anticipations of the Pauline doctrine of Man and Nature. The movement that began with Socratesin so far as any great movement can be said to have a beginning -prepared the way for the new era. But even in Plato the contrast is conspicuous. The $\mu \epsilon \lambda^{\prime} \tau \eta \eta$ tavátov, for example, of the Phaedo is less of a religious than an intellectual aspiration. Plato's "study of death" is inspired by the consciousness of ignorance, and the desire of knowledge, St Paul's by the sense of $\sin$ and the desire of holiness. With Plato the moral exaltation was a result of the intellectual; with St Paul it was the primary and immediate aim.

${ }^{2}$ Pittacus, according to Diog. Laert. I. 4. 78 , said $\phi i \lambda o \nu \mu \grave{\eta}$

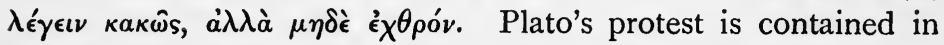
Rep. I. 335 в foll., in the Gorgias, and elsewhere.
${ }^{3}$ Fr. 13. 5, Bergk.
${ }^{4}$ Pyth. II. 83 ff.
II. 3. I 4 . 


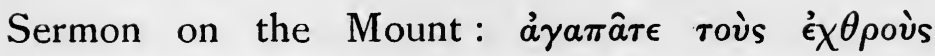

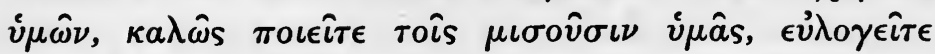

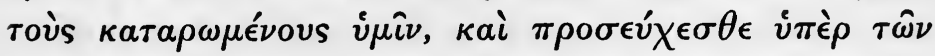

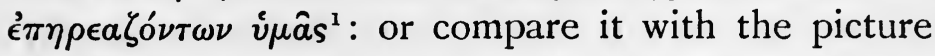

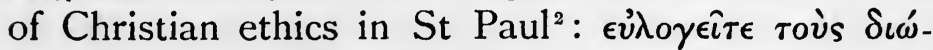

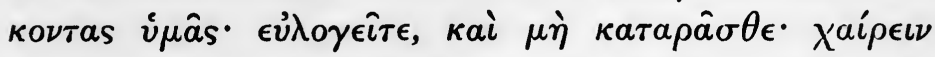

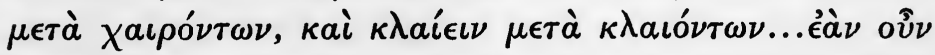

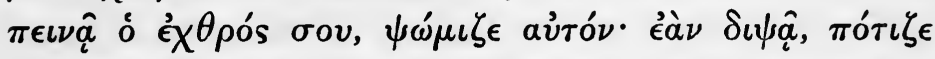

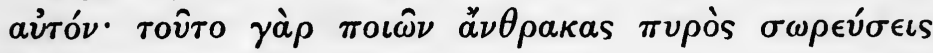

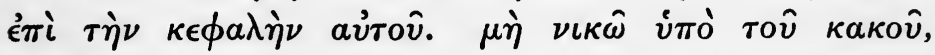

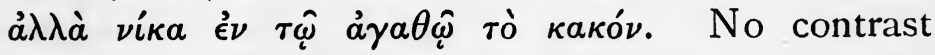
could be more emphatic or significant. It is impossible to realise the contradiction at all without receiving an intellectual stimulus: it is impossible fully to appreciate its meaning without a quickening of intellectual sympathy.

The examples which we have selected belong to the sphere of religion and ethics, but it would be easy to find instances in which the study of Greek antiquity in its psychology, its political theory and practice, its literature, its art, presents us with suggestive and stimulating contrasts to modern fashions and beliefs. In their psychological attitude, for example, the Greeks, true to their unifying instinct, recoiled from the habit of analysing the human mind with which we are familiar in the present day. Intellect, Will, and Emotion were often unified by the Greeks in Intellect. As a result of this unification, morality, which we now regard as,

${ }^{1}$ St Luke vi. 27.

${ }^{2}$ Rom. xii. 9-2 I, esp. vv. 14, I 5, 20, 2 I. 
primarily at all events, a condition of the will, was apt to be identified with an intellectual state. An inevitable consequence of this was the exaltation of the rational or intellectual side of human life over the emotional and moral. In modern Teutonic races the tendency is the other way. We need not dwell upon the striking differences between the political ideals and institutions of the ancients and our own. Their conception of the City State with all that it involved, and, in particular, the influence of this ideal in determining the relation between the individual and the State, these, and many other less fundamental contrasts, readily suggest themselves. Nor is it otherwise with ancient literature and art. It would be an excellent educative discipline to institute a comparison between the Classical and Romantic drama, or between Greek and English lyric poetry, or between ancient and modern ways of writing history. The study of ancient art and archaeology is not a liberal education unless it is pursued with the ulterior object of apprehending the spirit of Antiquity in its likeness and unlikeness to that of Christendom. The Parthenon should be interpreted by - shall we say?Lincoln Cathedral: Niobe weeping for her children by the Pietà of Michael Angelo.

Enough has been said to indicate generally the way in which the study of classical literature and life fulfils the first requisite of a liberal education by creating and fostering the spirit of intellectual sympathy. It remains for us to show how the 
discipline of ancient civilisation should mould and fashion the character.

To analyse the ideal man-the true likeness

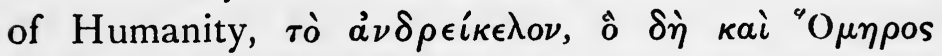

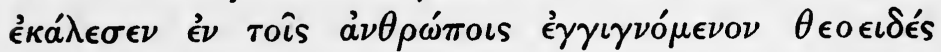

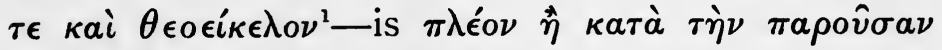
$\dot{\delta} \mu \eta^{\prime} \nu^{2}$ : but we can all recognise two elements of character, the blending of which in due proportion is as rare as it is splendid. The one we call by such names as steadiness, strength, sobriety, selfcontrol, the habit of obeying law; the other is called intellectual acuteness, originality, independence of mind, the capacity of making law. These are the two great factors which unite to form the characters of us all. Among Englishmen it is perhaps the steady element which predominates. This element is magnificent in action, after it has been told what to do, but, when confronted with an idea, it is apt to yawn, or to look at its watch, being, to put it somewhat bluntly, in the judgment at least of Frenchmen, a trifle stupid. In its noblest forms this virtue of character will make a school-boy lead a forlorn hope upon the battlefield, and meet a glorious death with the cry of Floreat Etona still ringing on his lips. In its degenerate forms it causes men to prize the body above the soul, and "esteem gymnastic more than music ${ }^{3}$."

The second factor in character, that which we have called originality, is less plentiful in the

1 Plato, Rep. vi. 50 I B.

2 Ibid. $506 \mathbf{E .}$

3 Plato, Rep. vin. 548 c. 
majority of men. It is often found in inverse proportion to the element of steadiness, and that is why genius-so we are wont to say-is often erratic and unstable. It is in virtue of this element that discoveries are made, and the limits of human knowledge extended; it is this that is the parent of the highest flights of poetry; it is this that founds religions and sways mankind, as the moon regulates the tides, with the magic force of an idea. But in its degraded forms, and when it is wrongly educated, it sinks into petty sophistry, makes havoc of great names, and convinces itself and others that the worse cause is the better, and so becomes a curse to the society wherein it appears. Corruptio optimi pessima.

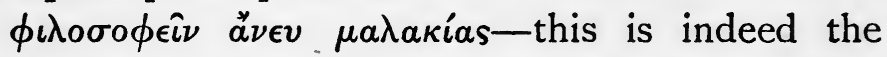
end. In the Politicus ${ }^{1}$ Plato wished to secure the presence of these two sides of character in children by intermarriages between men and women in whom the opposing elements predominated. It is wholly in the spirit of Plato's teaching to regard the ideal character as itself the product of the spiritual union of these two elements within the soul; and it is such a spiritual union that every attempt to educate the character should endeavour to effect.

We have still to show that the study of classical antiquity tends to cherish and to unify these two sides of the ideal man.

To know a thing, in the fullest sense of the term, is to become like the thing we know. Know- 
ledge is the assimilation of subject and object. This is the teaching of Christianity and Platonism alike: the one tells us that to know God is to be assimilated to $\mathrm{His}$ glorious image, the other that the knowledge of the Idea of Good or God, which is

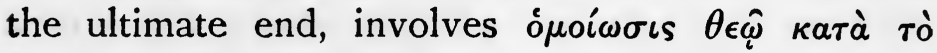
$\delta$ vvaró $\nu^{1}$. To know the best and highest in Greece and Rome is therefore to make the virtues of antiquity our own. For the purpose of educating the character by means of classical study, whatever is not best in ancient life and thought should, in the first instance at least, be ignored.

What then is the best of Greece, what is the best of Rome? To put the matter briefly, the genius of Greece was speculative, that of Rome was practical. The desire of knowledge, scepticism in its true and noble sense of searching after truth, is the dowry of ancient Greece; strength and selfcontrol, obedience and law belong to Rome. Full well did Virgil say:

excudent alii spirantia mollius aera,

credo equidem, vivos ducent de marmore voltus;

orabunt causas melius, caelique meatus

describent radio, et surgentia sidera dicent:

tu regere imperio populos, Romane, memento;

hae tibi erunt artes, pacisque imponere morem, parcere subiectis, et debellare superbos ${ }^{2}$.

Greece is in very truth the Mother of Ideas! How many seeds has she sown whose flowers and fruit delight and sustain us now! But the Greeks

1 Theaet. 176 в.

2 Aeneid vi. $848-854$. 


\section{The Value of Classical Education}

were relatively weak in action, because they knew not how to combine, since it is of the essence of genius to be individual. They could not translate into practice the ideas which they created; this honour was reserved for Christianity and Rome. The lofty ideals of morality which the Greek philosophers constructed reappear in Christian ethics, intensified, it is true, and intertwined more closely with the affections and the will, but easy to recognise, and in this profoundly human form sway still more powerfully the hearts of men. kai $\delta$

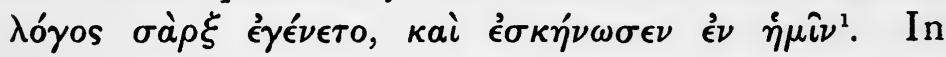
Rome, thanks to the national virtues of courage, and patience, and submission to authority, the ideas of law and government enunciated by Greek thinkers were translated into action, losing, perhaps, somewhat in the process, since practice is everywhere less perfect than theory, but keeping alive the sacred flame of civilisation, and spreading the pax Romana over the face of the Roman world.

And now let us sum up. The study of classical literature and life is a liberal education because it enlarges our intellectual horizon, and promotes intellectual sympathy by the electric shock of contradiction and the activity thus set up. It is a liberal education, in the second place, because it moulds the will and character no less than the intellect. As the student learns more of Greek life and thought, he should become more independent and more manly, not driven to and fro 
by every wind of doctrine, but honestly striving to think things out for himself, and building his faith on the sure ground of knowledge. In one word, he will love Truth more. As his knowledge of the life and language of Rome advances, he will become more patient and more courageous, he will learn "to scorn delights and live laborious days," he will become more loyal to himself, his country, and his faith, and become both a better citizen and a better man. In one word, he will love Law more.

The writer has spoken seriously, perhaps unduly so, upon this subject of classical study, because he feels that the issue is a great one: $\mu \epsilon^{\prime} \gamma a s \delta^{\prime} a j \omega \dot{\omega} \nu$,

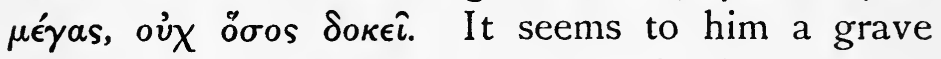
misfortune that any one should study classics without trying sooner or later to form some notion of what the study means. Every student and exponent of antiquity should frame his theory for himself, otherwise its educational value is but little.

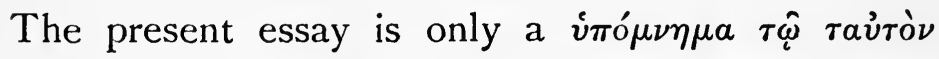

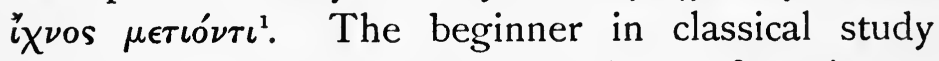
should be content at first to believe- $\delta \epsilon \hat{\imath} \gamma \dot{a} \rho \pi \iota$ -

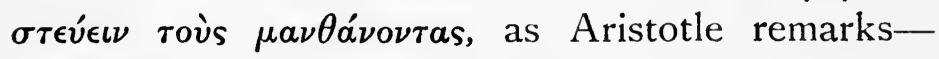
that there is a "beatific vision." Such a faith will animate and inspire the daily routine, and make the meanest particle breathe and live. He will begin by studying the body, if we may say so,

1 Plato, Phaedr. 276 D. 
of Greek thought, the beautiful language which is but the outward expression of inward and more

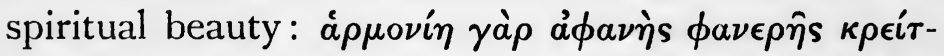
$\tau \omega \nu$. From the contemplation of bodily beauty he will rise to that of spiritual, and the soul of antiquity will reveal herself to him in the thoughts of ancient poets and philosophers and men of science, in ancient laws and institutions, in the immortal creations of ancient art and architecture. $\mathrm{He}$ will then recognise in the words of $\mathrm{Plato}^{1}$ o $\tau \iota$

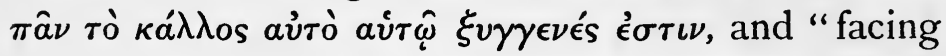
the full Sea of Beauty and looking thereon, he will beget out of bountiful Philosophy many beautiful and lofty conceptions and thoughts." The Sea of Beauty stretches wide, its waves unharvested as ever. We have merely stood upon the shore; he who scales the still snow citadels around it will see farther, but even he will not see all.

"Nay, come up hither...

Unto the furthest flood-brim look with me;

Then reach on with thy thought till it be drown'd.

Miles and miles distant though the last line be,

And though thy soul sail leagues and leagues beyond,

Still leagues beyond those leagues there is more sea."

${ }^{1}$ Symp. $210 \mathrm{C}-\mathrm{D}:$ 


\section{INDEX}

Aeschylus $40 \mathrm{f} ., 109,195,198 \mathrm{f.}$ Cleanthes, Hymn of 20, 82, $104 \mathrm{ff}$., 201, 210

Aether, doctrine of in Euripides 47 f., 53 ff., 130

Anaxagoras $42 \mathrm{ff} ., 53,205$

Anaximenes 44

Anthropomorphism and theomorphism $124 \mathrm{ff}$.

Aratus 19, $123 \mathrm{f}$.

Aristotle I, II, 22, 4I, 54, $63 \mathrm{f}$, $74,118,133$ f., I81, 199 f., 204, 227,237

Assimilation of man to God $33 \mathrm{f}$., 64 ff., 75, IIO, 235

Beauty, Ideal $68 \mathrm{ff}$.

Bias of Priene $85 \mathrm{f}$.

Body as tomb of soul $55,58,127$

Boethius 26

Brotherhood, universal 5, $142 \mathrm{ff}$. Browning, Robert 45, I60 f., 166 , 209

Cambridge Platonists $3,23,67$, $70,100,163$

Christ as $\log 0 \mathrm{I}_{58}$, I80 f., $\mathrm{I} 87 \mathrm{f}$.

Christianity: and pre-Christian religion $184 \mathrm{ff}$., $228 \mathrm{ff}$ : and Stoicism $178 \mathrm{ff}$.

Chrysippus 114, 170, 179, 206

Cicero 140, 143, 146, 157, 222

City of God 65, 229

Classical education, value of $213 \mathrm{ff}$.: as discipline of character $233 \mathrm{ff}$. I95: life of I $3 \mathrm{ff}$.

Clement of Alexandria 2 f., 20, 55, 91, 99, I I 2, 153, I 88 f., 190

Cohesion, Stoic 155

Cosmopolitanism $143 \mathrm{ff}$.

Dante II, 5I, 6I f., 70, I 32

Death, rehearsal of $65 \mathrm{ff}$., 230 : Greek view of $225 \mathrm{ff}$.

Dialectic, Plato's 29 f., 72 ff.

Diogenes of Apollonia $44 \mathrm{ff}$., 59, 129

Divinity of human soul $3,35 \mathrm{ff}$., $127 \mathrm{ff}$.

Dualism, in disguise $17 \mathrm{I} \mathbf{f}$ : as explanation of evil 204: as basis for morality 208

Education, Plato's theory of $28 \mathrm{ff}$., $70 \mathrm{ff}$ : liberal and professional $215 \mathrm{ff}$.

Empedocles 127, 204

Epicharmus 53, $93 \mathrm{ff}$.

Epictetus 122, 134, 136 ff., 168, I76, 179, 183

Epicureans 19, I14, I82

Euripides 42 f., 45 ff., 64 f., 129 , 192 Evil, physical and moral 165 , 169 f., 211 : pantheistic view of I $70 \mathrm{ff}$ : : Greek consciousness of I 9 I ff. : ascribed to Gods 193 f. : as punishment for $\sin 194 \mathrm{ff}$ : explained by dualism 204 Ezekiel 197 
Fate, Stoic 155, I73 f.

Fire, Logos identified with, 77,

$88 \mathrm{ff}$ : creative, in Stoicism I $50 \mathrm{f}$.

Free will 152 f., 172 ff.

God: and Nature Io f., I3 f., $48 \mathrm{ff}$., I 48 ff., 227 ff. : kinship of man' with $19 \mathrm{ff}$., $38 \mathrm{ff}$., $5 \mathrm{I}$, $60 \mathrm{ff}$., I $22 \mathrm{ff}$. : as Air $44 \mathrm{ff}$. : as Reason 23, 29, 44, 48, 50 ff., $56 \mathrm{ff}$., $60 \mathrm{ff}$., $77 \mathrm{ff}$., I I9, 156 : as Idea of Good 22 f., 132 : gradual spiritualisation of $108 \mathrm{ff}$ : : universality of $119 \mathrm{ff}$ : as unification of the world $156 \mathrm{f}$.

Gods as authors of evil $193 \mathrm{f}$.

Greek genius $235 \mathrm{f}$.

Greeks, unifying instinct of $23 \mathrm{I} \mathrm{f}$.

Harmony of opposites $96 \mathrm{ff}$., 164 ff., 209 ff.

Heraclitus 38, 40, 65, 77 ff., I I 2 , I I 5, I 17 f., I 20, I25, I 38 , I 50 ff., I63 ff., I 85 f., $209 \mathrm{f}$.

Herbert, George 21, 128, 207

Hesiod 86, 125

Homeric poems 37, 39, 64, $108 \mathrm{ff}$., I 24 ff., I63, I72, I 92 ff., 233

Ideal Beauty $68 \mathrm{ff}$.

Ideas, theory of Io, $22 \mathrm{ff}$., I3 $1 \mathrm{f}$. Immortality: see Soul

Infinite in the individual $\mathrm{I} 66 \mathrm{ff}$.

Innate notions 140

Jeremiah $196 \mathrm{f}$.

Jesus, sayings of 158

Job, Book of 201, 203

Justin Martyr 2, 20, 177 f., I86, I 88,190
Logos, in Heraclitus $77 \mathrm{ff}$ : as harmony of opposites $97 \mathrm{ff}$ : Stoic I49 ff.: as Christ 158, I $80 \mathrm{f}$., I $84 \mathrm{ff}$ : : in Philo I $84 \mathrm{f}$.

Lotze, metaphysical doctrines of, applied to Plato 2

Man, essential divinity of $19 \mathrm{ff}$, $38 \mathrm{ff}$., $50 \mathrm{ff}$., $60 \mathrm{ff}$., $122 \mathrm{ff}$.

Marcus Aurelius 50, 54, 60, 68, $83,134 \mathrm{ff}$.

Meditatio mortis $65 \mathrm{ff}, 230$

Michael Angelo and Platonism $4,29,70$

Morality, dualism as basis for 208: Stoic $136 \mathrm{ff}$ : pagan and Christian $230 \mathrm{f}$.

Nature, life in harmony with I4, $148 \mathrm{ff}$.: soul of plants in Stoicism $155 \mathrm{f}$.

Nature-mysticism $49 \mathrm{ff}$. See also God and Nature

Necessity and Reason Io, $205 \mathrm{f}$. Necrosis $66 \mathrm{ff}$.

Noocracy 55

Nous 39 f., 53,56 f., 66: Anaxagoras' doctrine of $42 \mathrm{ff}$ : and pneuma 53 f., I30, I34, I $54 \mathrm{f}$. See also Reason and God

Origen 2, 20, 27, 178

Orphics 14, 35, 55, I 28

Pantheism, poetical: see NatureMysticism: Stoic I 16 and see also God and Nature and Stoics : moral evil denied in 172,211 : replaced by theism 184

Personality, motive principle of 180 
Philo 98, I64, I84

Philosophy: and poetry, feud between $108 \mathrm{ff}$. : as preparation for Christianity $185 \mathrm{ff}$.

Pindar I3 f., 35 ff., I22, 125 f., 129, 134, 192, 196, 230

Plato: his influence on poets and artists $3 \mathrm{f}$.: his hostility to Greek ideas $5 \mathrm{f}$. : appeals to universal human instincts $7 \mathrm{f}$ : : his view of Nature $9 \mathrm{ff}$ : : his theory of Ideas IO, 22, $64 \mathrm{ff}$, I3 I f.: founds theological view of universe $\mathrm{II}$ : his view of man $12 \mathrm{ff}$., 19, $59 \mathrm{ff}$., $130 \mathrm{ff}$ : : and Wordsworth $9,14 \mathrm{ff}$. : his teaching on pre-existence and immortality $24 \mathrm{ff}$ : : his theory of education $28 \mathrm{ff}$., $70 \mathrm{ff}$., $220 \mathrm{ff}$ : his doctrine of assimilation to God $33 \mathrm{f}$, $64 \mathrm{ff}$., $75:$ his hope of ultimate perfection $8,74 \mathrm{f}$.

Pliny, the elder 224

Pneuma and Nous 53 f., I 30, I 34, I $54 \mathrm{f}$.

Predestination $173 \mathrm{f}$.

Pythagoreans 14, 55, 58, 86, I27

Reason: and Necessity 10, 205 : as eye of soul 28,217 : as element of God in man $12 \mathrm{ff}$., 29, $50 \mathrm{ff}$., $56 \mathrm{ff}$., $60 \mathrm{ff}$., $129 \mathrm{ff}$ : : as spiritual life 67 : as attribute of Logos in Heraclitus $77 \mathrm{ff}$., 92 : in Stoicism $149 \mathrm{ff}$. See also Nous and God

Rehearsal of death $65 \mathrm{ff}$., 230 Religion, unity of $186 \mathrm{ff}$.

Reminiscence, doctrine of $25 \mathrm{ff}$. Roman genius $235 \mathrm{f}$.
St John 152, 157, I 84 ff.

St Paul 19, 25, 53 f., 63, 66 ff., 75, $122 \mathrm{ff}$., 139, I68, 207, $228 \mathrm{ff}$.

Self-realisation, Stoic I4I f.

Seneca 138, I42 f., 179, I 84

Shorthouse on Wordsworth's Platonism $14 \mathrm{ff}$.

Simonides 201, 223

Socrates 12, 34, 55 ff., I86, 221, 230

Solon I9I ff., 195, 230

Sophocles 4I, IO8 ff., I92, I95, 202, 2 10, $218 \mathrm{f}$.

Soul: of the World, see WorldSoul: immortality of $24 \mathrm{ff}$, 38 ff., 75, I79 f.: Homeric notion of 37 : in lyric poets and tragedy $40 \mathrm{ff}$ : : celestial origin of $19 \mathrm{ff}$., $35 \mathrm{ff}$ : and body 55 , $57 \mathrm{f}$., $127 \mathrm{f}$.

Spinoza I16, 170 f., 211

Stoicism : and Christianity $178 \mathrm{ff}$ : and Judaism 1 i $5 \mathrm{ff}$.

Stoics 14, 19, 24, 40, 50, 53, 60, $63,78,85,94$ ff., 102 f., 108, I 2 ff., I 33 ff., $210 \mathrm{f}$.

Subliminal self as argument for immortality 39

Suffering: and evil $190 \mathrm{ff}$ : as discipline $200 \mathrm{ff}$ : : as part of universal harmony $209 \mathrm{ff}$.

Swinburne 76

Tennyson 9, 20, 22, 26, $49 \mathrm{f}$.

Tension, Stoic $155 \mathrm{f}$.

Tertullian 6, 152

Theism I 54, 184

Theognis 195, 200

Thunderbolt, the ever-living $149 \mathrm{ff}$.

Universal brotherhood $5,142 \mathrm{ff}$. 
Universe, Soul of, see World- Wordsworth: and Plato $14 \mathrm{ff}$., Soul 27: and Euripides $48 \mathrm{f.}:$ and Logos I $59 \mathrm{ff}$.

Vaughan, Henry I48, 175

World-citizenship I $43 \mathrm{ff}$.

Virtue and vice, gulf between 172 World-Soul Io f., 59 f., I54, 206

Wisdom of Solomon 27, 194, 203

Wise Man, Stoic and Epicurean I $82 \mathrm{ff}$.

Word, Universal, see Logos and Reason

Xenophanes 64, 86, II If. Xenophon $55 \mathrm{ff}$.

Zeno I I3 f., I 34, I44, $173 \mathrm{f}$. 







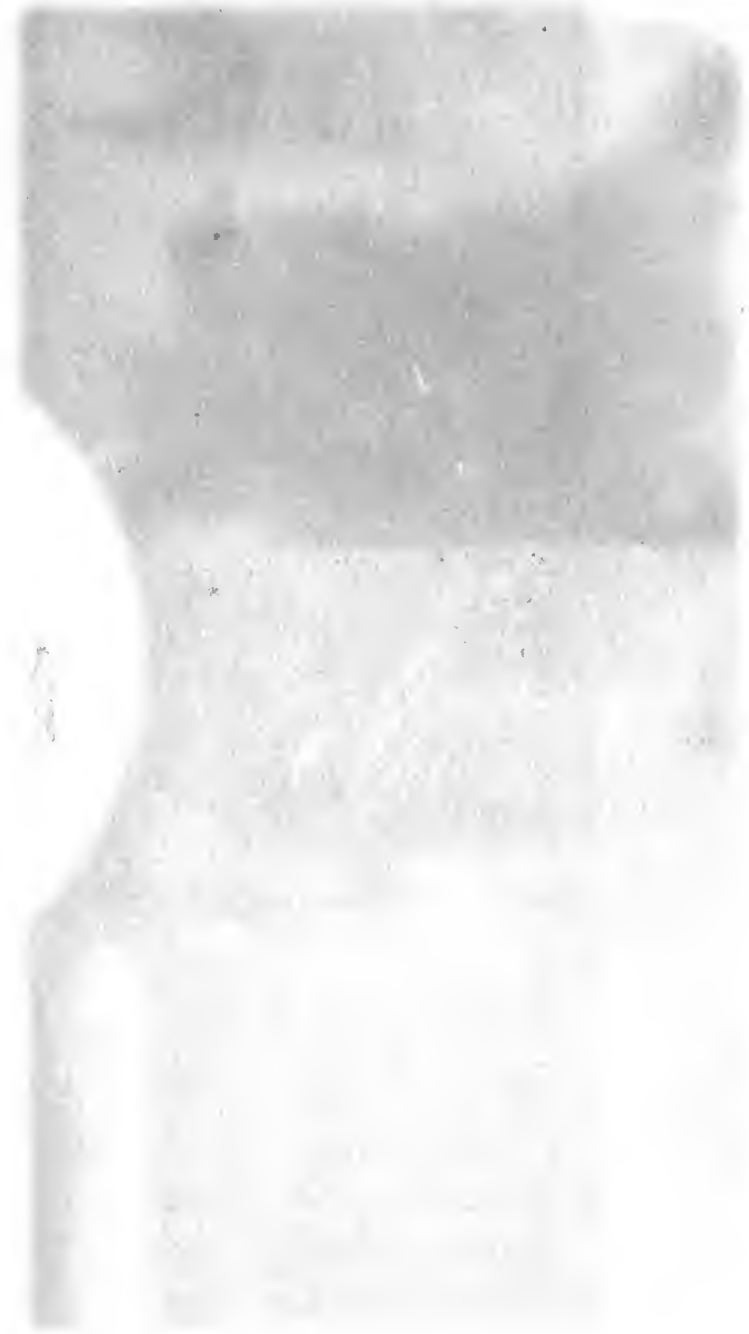




\section{PLEASE DO NOT REMOVE}

CARDS OR SLIPS FROM THIS POCKET

\section{UNIVERSITY OF TORONTO LIBRARY}

B Adam, James

181 The vitality of Platonism A35 


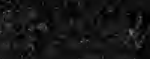

(4) in $-x^{2}+x^{2}+y^{2}=$

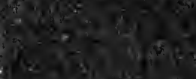

$t^{2} x^{2}=\sin ^{3} \operatorname{lin}^{2}$

1.

(3)

+6.

19.

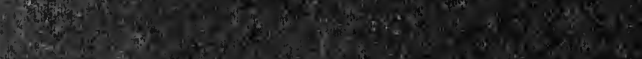

$x^{4}\left(\cos ^{2}+2\right)$

(3)

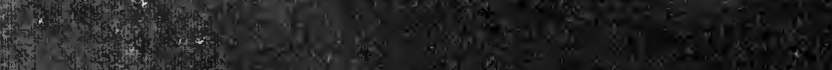

(1)

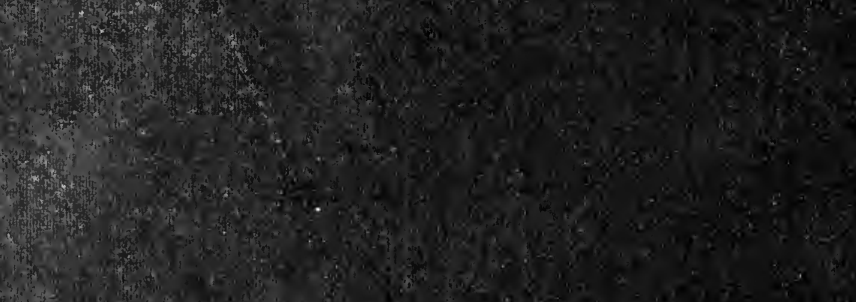

(2)

(2)

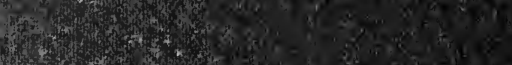

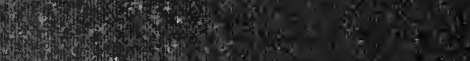

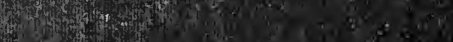

He

3.

W. Hif

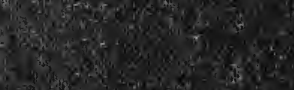

